INTERNATIONAL MONETARY FUND

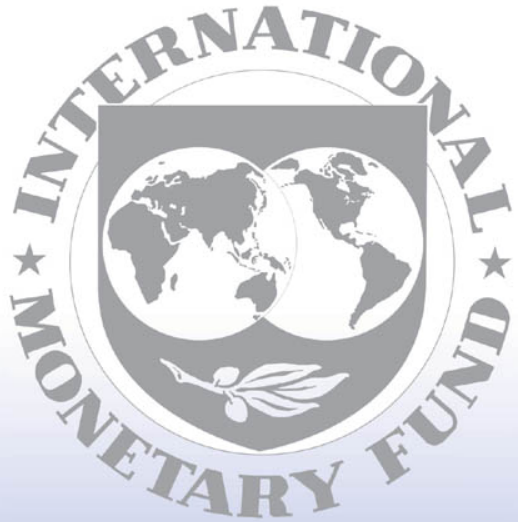

Staff

Country

Reports 


\section{Kingdom of the Netherlands-Netherlands: 2011 Article IV Consultation-Staff Report; Staff Statement; Public Information Notice on the Executive Board Discussion; and Statement by the Executive Director for the Kingdom of the Netherlands- Netherlands}

Under Article IV of the IMF's Articles of Agreement, the IMF holds bilateral discussions with members, usually every year. In the context of the 2011 Article IV consultation with the Kingdom of the Netherlands - Netherlands, the following documents have been released and are included in this package:

- $\quad$ The staff report for the 2011 Article IV consultation, prepared by a staff team of the IMF, following discussions that ended on March 28, 2011, with the officials of the Kingdom of the Netherlands - Netherlands on economic developments and policies. Based on information available at the time of these discussions, the staff report was completed on May 19, 2011. The views expressed in the staff report are those of the staff team and do not necessarily reflect the views of the Executive Board of the IMF.

- $\quad$ A staff statement of June 7, 2011 updating information on recent developments.

- $\quad$ A Public Information Notice (PIN) summarizing the views of the Executive Board as expressed during its June 10, 2011 discussion of the staff report that concluded the Article IV consultation.

- $\quad$ A statement by the Executive Director for the Kingdom of the Netherlands-Netherlands.

The document listed below has been or will be separately released.

Selected Issues and Analytical Notes.

The policy of publication of staff reports and other documents allows for the deletion of market-sensitive information.

Copies of this report are available to the public from

International Monetary Fund $\bullet$ Publication Services

$70019^{\text {th }}$ Street, N.W. $\bullet$ Washington, D.C. 20431

Telephone: (202) 623-7430 • Telefax: (202) 623-7201

E-mail: publications@imf.org Internet: http://www.imf.org

Price: $\$ 18.00$ a copy

International Monetary Fund

Washington, D.C. 
INTERNATIONAL MONETARY FUND

KINGDOM OF THE NETHERLANDS-NETHERLANDS

Staff Report for the 2011 Article IV Consultation

Prepared by the Staff Representatives for the 2011 Consultation with the Netherlands

Approved by Ajai Chopra and Jan Kees Martijn

May 19, 2011

\section{EXECUTIVE SUMMARY}

Recovery has commenced but is still frail. The upturn has been fueled by strong exports. Inflation has remained muted, but is now picking up because of rising oil prices. External competitiveness is adequate. Subdued continuation of the recovery is projected for 2011-12, with output remaining below potential and somewhat higher inflation. Risks - primarily from external sources - appear tilted downwards. The authorities broadly agreed. Their forecast is only slightly more optimistic.

The consensus was that housing market vulnerabilities must be addressed promptly and staff urged deeper reforms. Authorities' plans to limit the maximum LTV ratio and impose minimum principal repayments are positive, but further tightening of LTV ratios and principal repayments and setting greater risk weights on high LTV mortgages would be useful. Moreover, a credible statement that mortgage interest deductibility (MID) will be gradually reduced would eliminate uncertainty. The authorities noted that a coalition agreement prevented action on MID in the near future.

Following the FSAP update, officials are further buttressing effectiveness of supervision and crisis resolution mechanisms. The authorities concurred that bank capital buffers appear adequate, though progress toward meeting Basel III requirements is warranted. Areas for improvement include rule-making authority and legal protection of supervisors; adequacy of data reporting requirements; resource limitations; and the crisis resolution framework. Welcome efforts are being made to address these issues as well as to develop macro-prudential instruments, but further action is needed.

The authorities agreed that flexible implementation of the planned fiscal adjustment was desirable, but only for very severe shocks to the recovery. Staff maintained that, should the recovery stall, functioning of automatic stabilizers ought to be unhindered and contingency plans developed to moderate the discretionary adjustment. Officials considered automatic stabilizers on revenues to be sufficiently large. Discretionary action would only be justified by clear danger of another major recession. Staff noted however that, under existing rules, automatic stabilizers would be capped if the deficit exceeded the plan by 1 percent of GDP. There was also agreement that consolidation will need to continue beyond 2015 to ensure fiscal sustainability, including by reassessment of pension fund benefits.

The authorities concurred that structural reforms would alleviate the adverse impacts of the crisis and population aging on growth. Concrete new initiatives however appear limited. 
Executive Summary $\underline{1}$

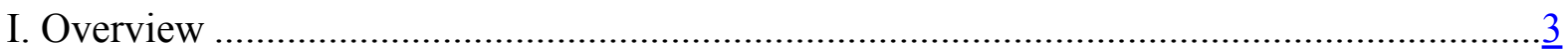

II. Recent Economic Developments and Outlook..................................................................

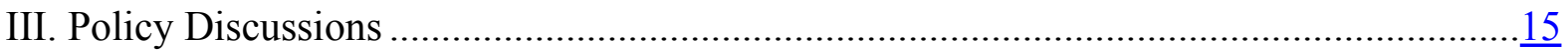

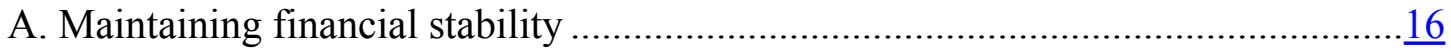

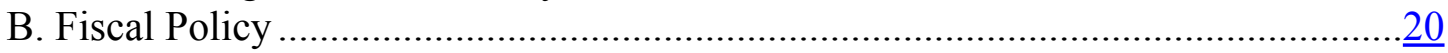

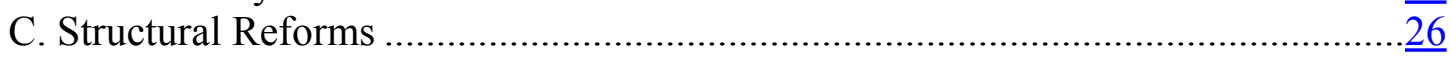

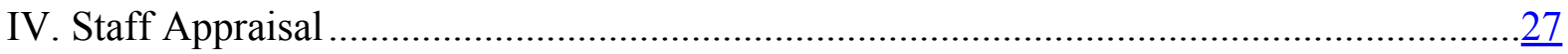

Tables

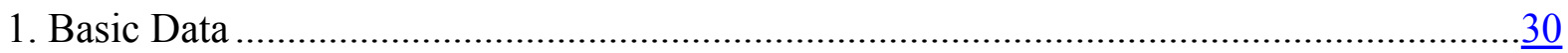

2. Indicators of External and Financial Vulnerability, 2003-10 ............................................

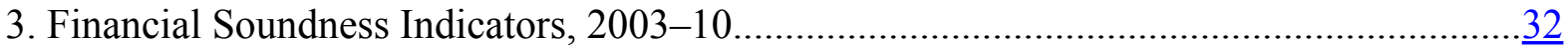

4. Summary of State Interventions in Major Financial Institutions .....................................33

5a. General Government Statement of Operations, 2004-12 …..........................................

5b. General Government Integrated Balance Sheet, 2004-09 …..........................................

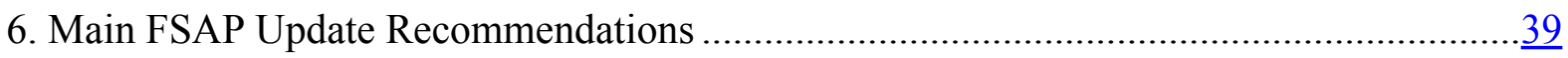

7. Proposed Structural Fiscal Measures …………….....................................................

8. Policy Responses to the Recommendation to Improve Labor Supply.................................42

Figures

1. International Comparisons of Financial Markets ...........................................................

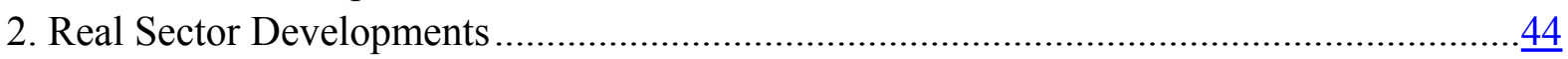

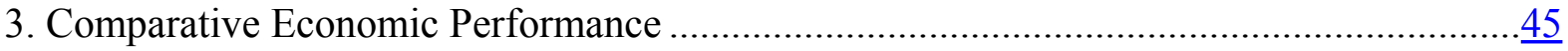

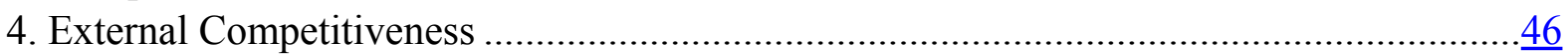

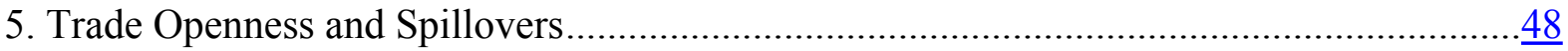

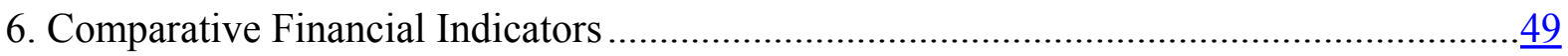

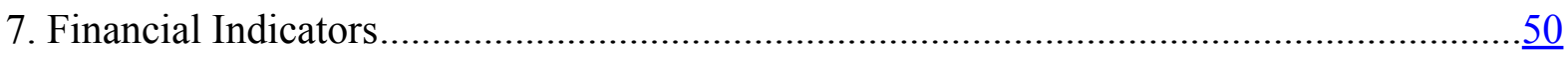

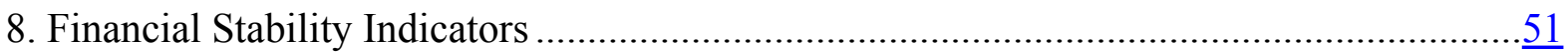

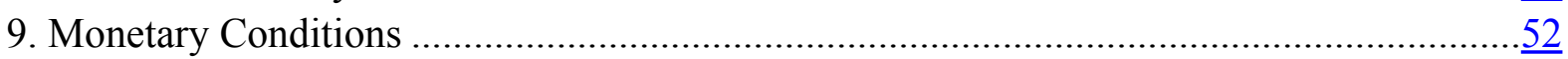

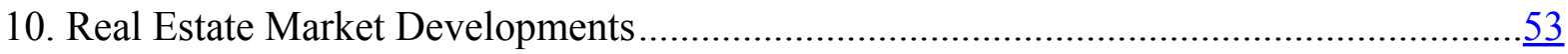

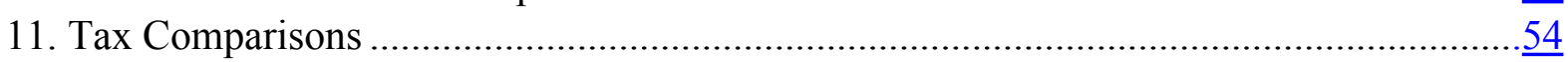

Boxes

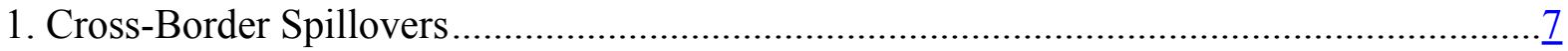

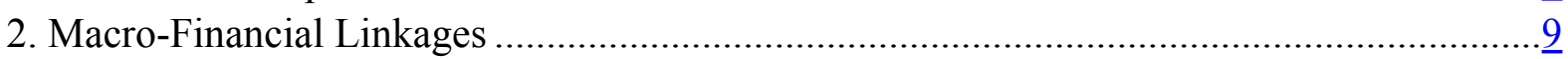

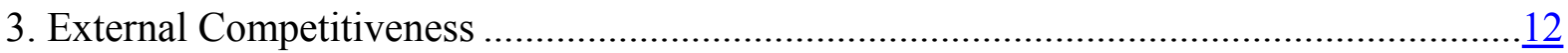




\section{OVERVIEW}

\section{Despite robust fundamentals, the crisis hit the Netherlands hard, because of} adverse international spillovers, especially in the financial sector. Growth was above the euro area average during most of the decade leading to the crisis, the external current account exhibited sizable surpluses, and the fiscal position was strong, with low public debt. No major bubbles were evident in domestic asset markets, but owing to a relatively large financial sector and sizable foreign financial and trade exposures, economic activity took a major blow. Several large financial institutions had to be rescued by the government through nationalization, massive capital infusions, and other support (Figure 1; Boxes 1 and 2).

\section{Recovery has commenced, but significant vulnerabilities remain. Although} growth has resumed, it is significantly weaker than before the crisis. Moreover, spreading unease in sovereign debt markets and the possibility of a worse-than-anticipated impact of domestic and EU-wide fiscal tightening could darken prospects for a continuation of the recovery and even threaten financial stability, if banks in major advanced countries are affected. The housing market remains a notable domestic risk, while aging weighs on fiscal sustainability and potential growth.

\section{RECENT ECONOMIC DEVELOPMENTS AND OUTLOOK}

\section{The Netherlands emerged from a deep recession in mid-2009, as the world} economy gained strength, but the resurgence remains frail. Notwithstanding positive quarterly growth from Q3 2009, real GDP fell by 4 percent overall in 2009. The recession was spawned by collapsing exports, investment cutbacks, and massive destocking, amid near-record declines in capacity utilization and confidence (Figures 2 and 3; Tables 1 and 2). Domestic demand contracted much less, as still-substantial wage rises cushioned private consumption. Conversely, the subsequent upturn, with growth of $13 / 4$ percent in 2010 , has been stimulated by the recovery of international trade, leading to a strong pick-up of exports and restocking.

\section{Unemployment has risen modestly, with} subdued price and wage inflation. Despite the large output contraction, the unemployment rate increased only marginally in 2009 and peaked in 2010 at $4 \frac{1}{2}$ percent, well below Okun's law predictions. Enterprises' reluctance to shed labor, sustained by ample profitability buffers, helped suppress or delay unemployment buildup, while government-subsidized temporary reduced-hours schemes played a minor role. ${ }^{1}$ Inflation fell

\footnotetext{
${ }^{1}$ See Analytical Note 1 (AN1).
}

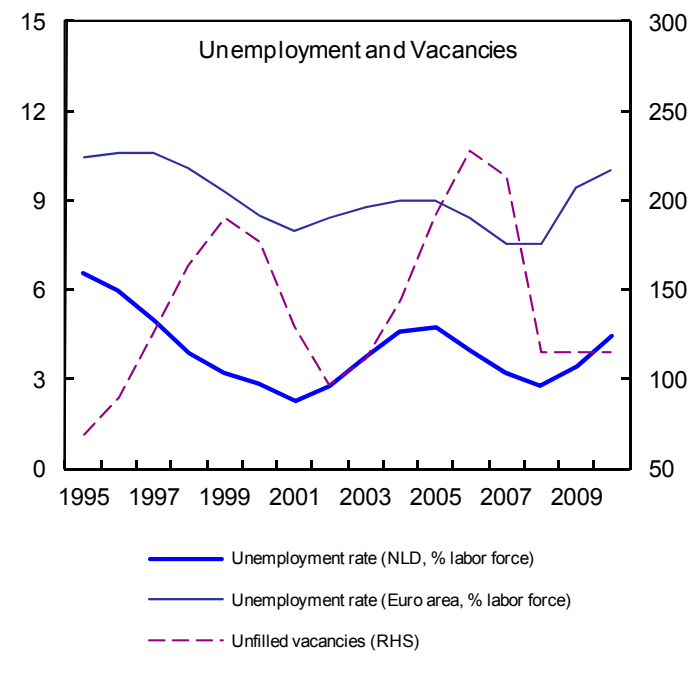

Sources: Global Insight; and IMF, WEO 
sharply in mid-2009 with cuts in electricity and gas tariffs, and stayed low, at less than 1 percent in 2010, as recession created economic slack. Accordingly, wage growth contracted by more than half, to about $1 \frac{1 / 4}{4}$ percent in 2010 . However, in recent months inflation has risen sharply to about 2 percent - as in much of Europe - reflecting largely buoyant oil and commodity prices.

\section{Banking system soundness has improved significantly since 2008 , but fragilities} persist (Table 3 and 4; Figures 6-9).

- $\quad$ Although, the (unweighted) capital-toasset ratio is still comparatively low, all large banks maintain capital well above minimum requirements, largely due to government intervention. The banking sector capital adequacy ratio (CAR) stood at 13.9 percent as of end-2010, comprised mostly of core Tier 1 capital. Deleveraging helped raise the Tier 1 ratio above the average of major European counterparts.

- $\quad$ Despite deterioration in asset quality in 2009, the NPL ratio remained at manageable levels (less than 3 percent of total loans) for the banking sector as of June 2010.

- $\quad$ Bank profitability has recovered slightly but remains weak. Banks achieved a modest operating profit in 2009-10, driven by increased interest income, but hobbled by higher operating expenses and persistently large provisions due to servicing arrears. Liquid assets more than cover short-term liabilities; nevertheless funding risk remains a challenge given Dutch banks' reliance on wholesale market funding.

- $\quad$ The foreign exposure (foreign loans to total loans) of the Dutch banking sector has fallen from its 71 percent peak before the crisis to 46 percent by end- 2010 .

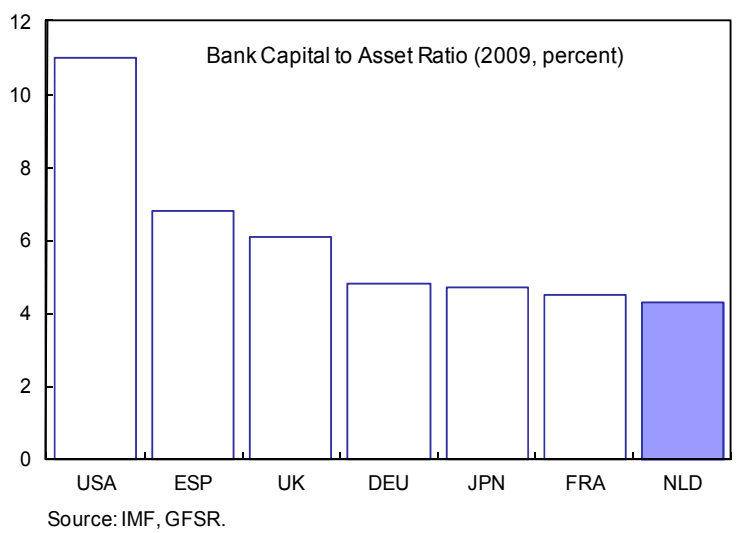

Financial Stress in the Netherlands has eased significantly.

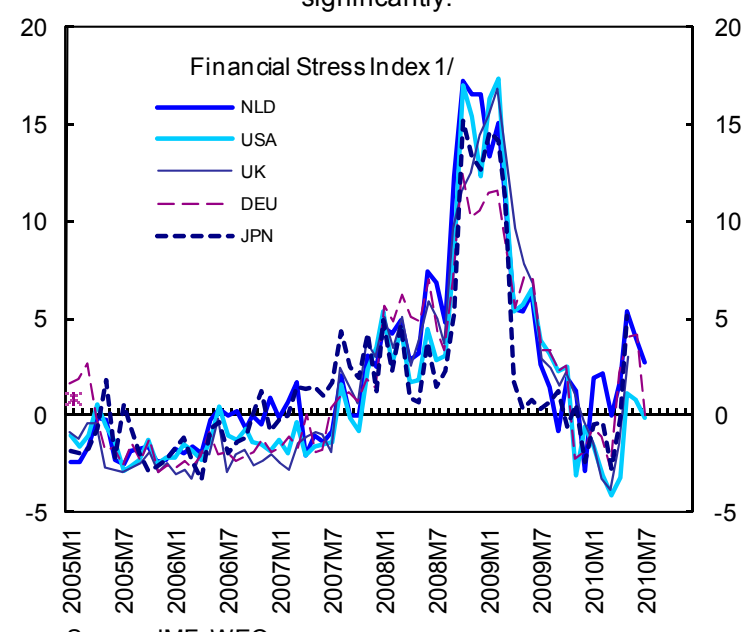

Source: IMF, WEO.

$1 /$ A positive value implies strain

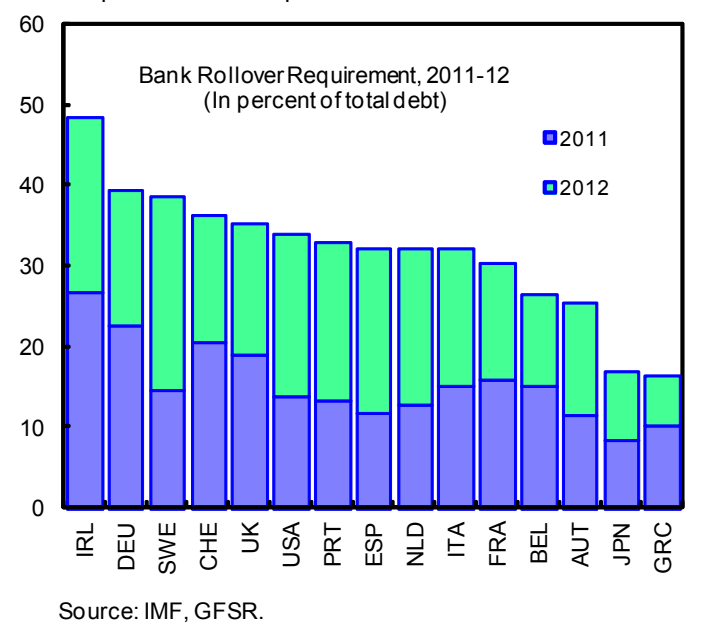




\section{A strategy of gradual exit from extraordinary policy support is being} implemented, amid continued restructuring of the financial sector. At the beginning of 2011, the authorities ended access to the bank credit guarantee program. Three Dutch financial institutions, AEGON, SNS Reaal and ING, have paid back part of the capital support provided by the government in 2008-09. The state guarantee for the mortgage portfolio of ABN Amro was terminated in October 2010, and ABN Amro is expected to complete its merger with Fortis Bank Nederland by end-2011.

\section{Coverage ratios of pension funds are low amid widespread uncertainty on}

future benefits and insurers also face important challenges. After a temporary improvement, the average coverage ratio dropped under 95 percent in Q3 of 2010 and has since recovered to just above the statutory minimum of 105 percent — compressed by increasing pension liabilities, both from extended longevity and continued low interest rates. DNB has requested development of recovery plans by many funds. Nevertheless, with the low interest rate environment expected to persist in the medium-term, indexation of benefits has been widely abandoned during the crisis, and even maintenance of commitments in nominal terms is in question in many funds. Average solvency ratios of life insurers have decreased significantly and profitability

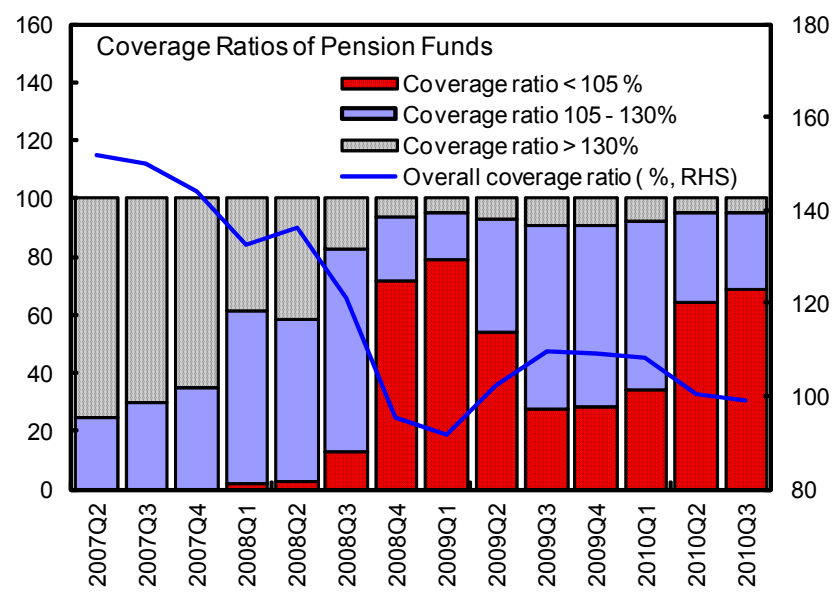
is also threatened, mainly because sales of individual life policies collapsed in 2009 . Nonlife insurers appear to have weathered the crisis better.

\section{Household balance sheets appear relatively comfortable, but vulnerabilities are} rising. Net financial assets of households have recovered from the lows of 2008-09. However, household debt has risen steadily to over 270 percent of disposable income in 2010, among the highest in advanced economies. In addition, the loan-to-value (LTV) ratio of new mortgages has surged, exceeding 120 percent in 2010. Liberal mortgage interest tax deductibility (MID) has put upward pressure on mortgage size, and also led to the proliferation of interest-only non-amortizing mortgages - frequently with principal accumulated in separate investment/insurance accounts - since the mid-1990s. Data on the separately accumulated principal is unavailable, but the DNB believes such principal to be relatively modest. With banks having first charge at default, and full recourse against borrowers, mortgage default rates remain very low. However, fiscal consolidation and increased unemployment could exert significant pressure on household disposable income. 


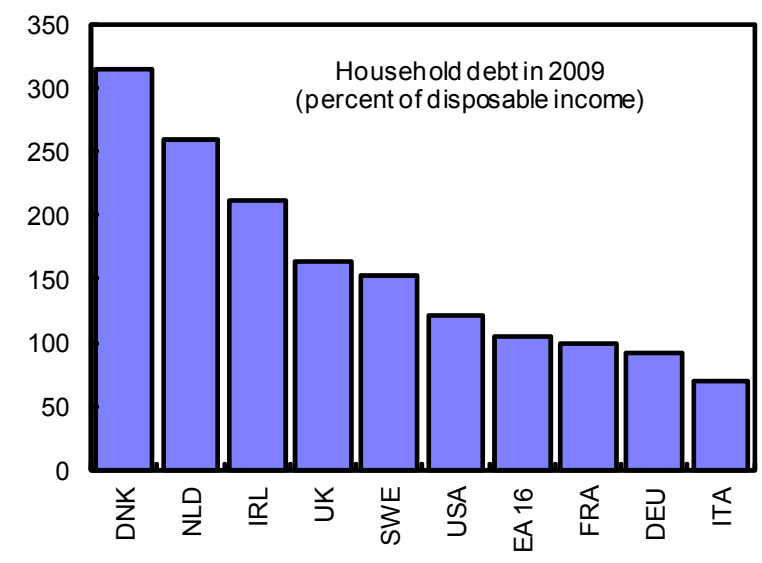

Source: Haver

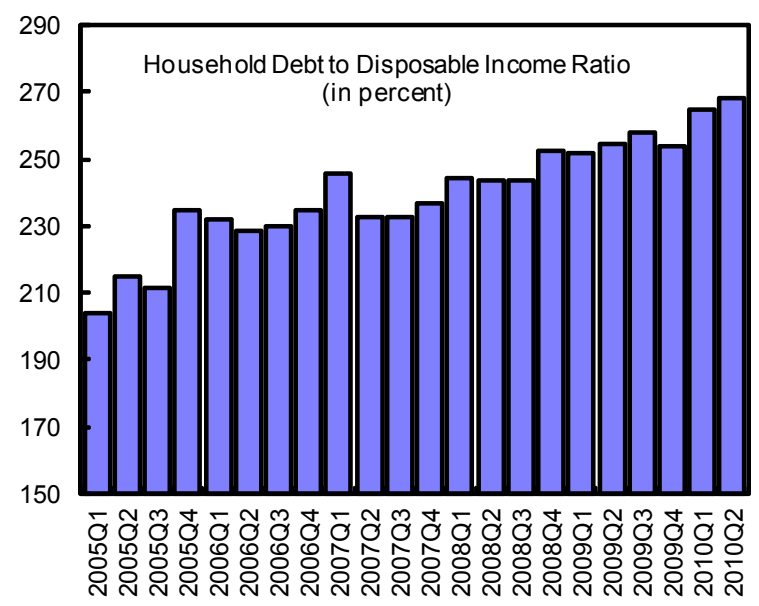

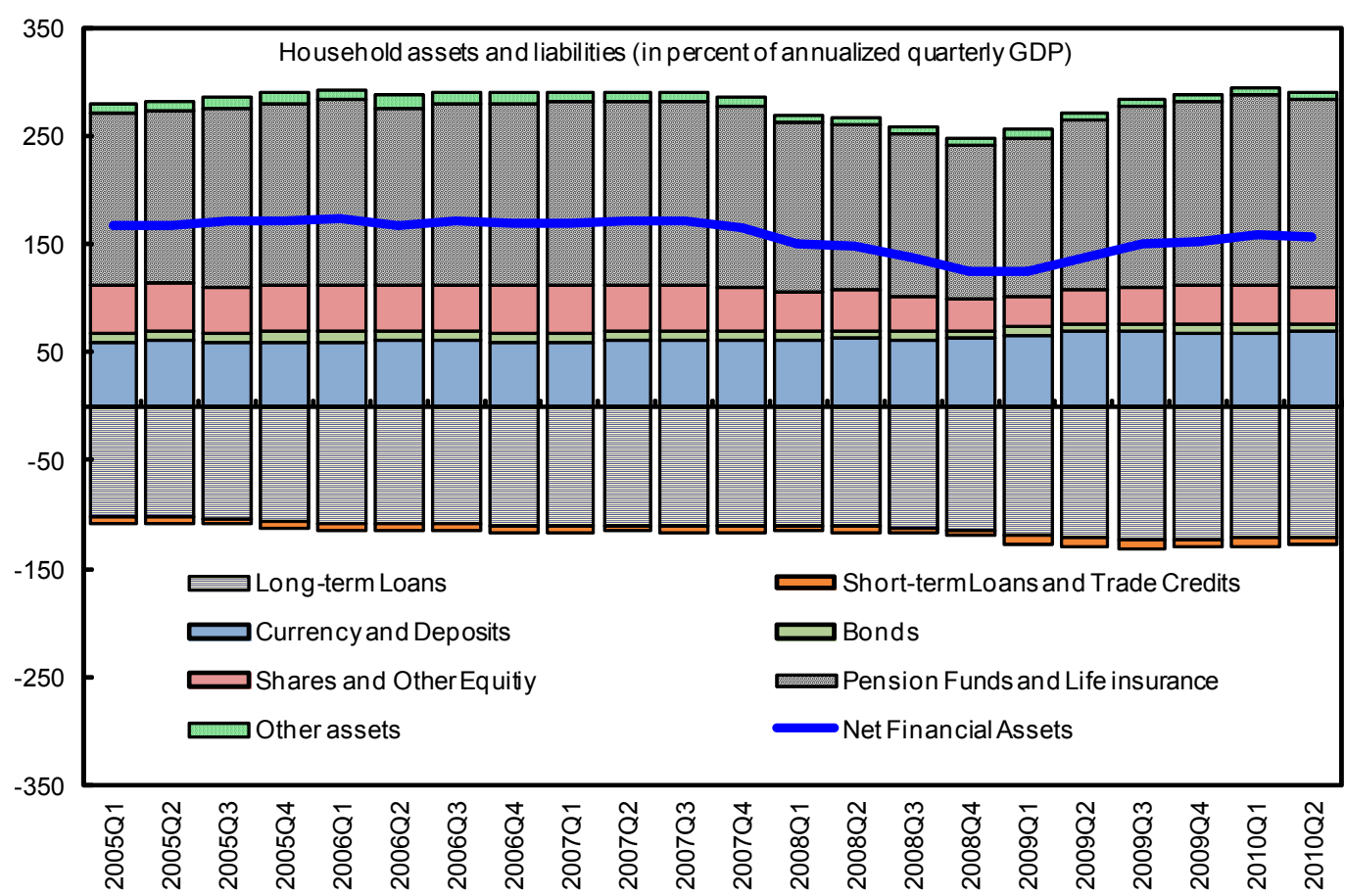




\section{Box 1. Netherlands: Cross-Border Spillovers ${ }^{1}$}

Regional concentration of exports exposes the Netherlands to correction in the external position of developed countries. A comparatively high 77 percent of Dutch exports are directed to European countries. Only about 15 percent goes to emerging markets and developing countries, with less than 3 percent of total exports to Asia. Dutch exports are thus more vulnerable to faltering demand in advanced economies, particularly European, than many other euro area member countries.

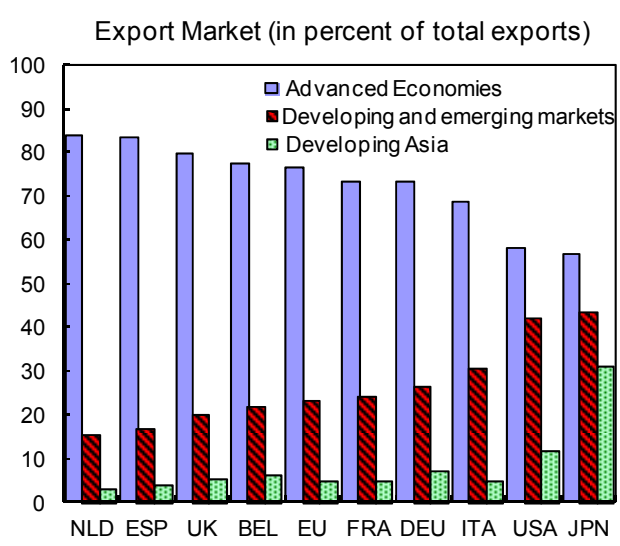

Fiscal consolidation in trading partners could impact significantly export and GDP growth. Several of the main markets for Dutch exports are expected to reduce fiscal deficits markedly over the short- to medium-run. Simulation results indicate that fiscal consolidation in the Netherlands' trading partners is likely to reduce GDP growth by close to $1 / 2$ percentage points in 2012 , almost equivalent to the negative effect from domestic consolidation. The extent of fiscal spillovers in the Netherlands is well above the PPP-weighted average for a sample of 20 countries. Fiscal consolidation in Germany, France, the United States, and the UK accounts for 78 percent of the adjustment spillovers to

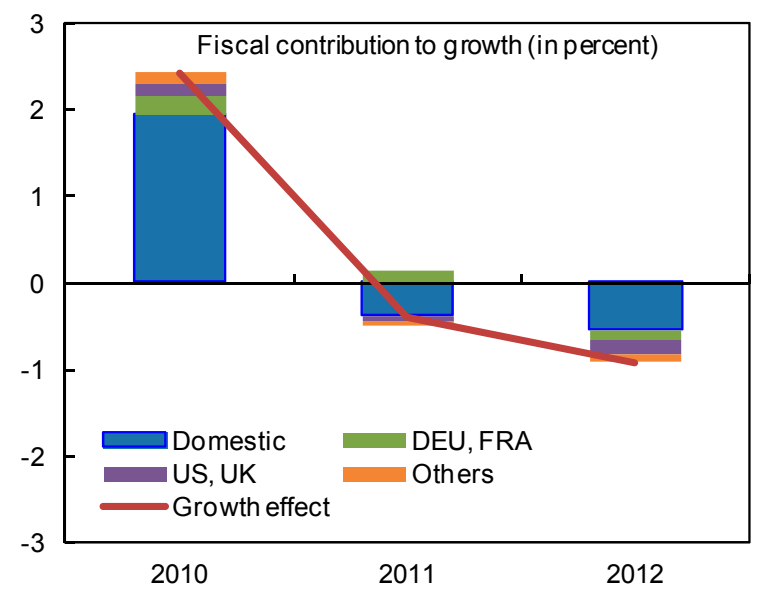
the Netherlands.

The concentration of financial claims abroad and the high degree of openness render the Netherlands quite susceptible to foreign default. Simulating the direct and indirect effects of a default in one or more of the major partners indicates sizeable losses to Dutch lenders. For example, a default on 10 percent of international claims on the US could generate a loss of 3.1 percent of GDP. Corresponding values for the UK, Germany or Spain are 1.6, 1 and 0.9 percent of GDP. While financial exposure remains high by international standard, the decrease in claims abroad relative to GDP from 315 percent in 2007 before the crisis to 160 percent in mid-2010 has reduced potential default losses appreciably.

\footnotetext{
${ }^{1}$ See AN2.
} 


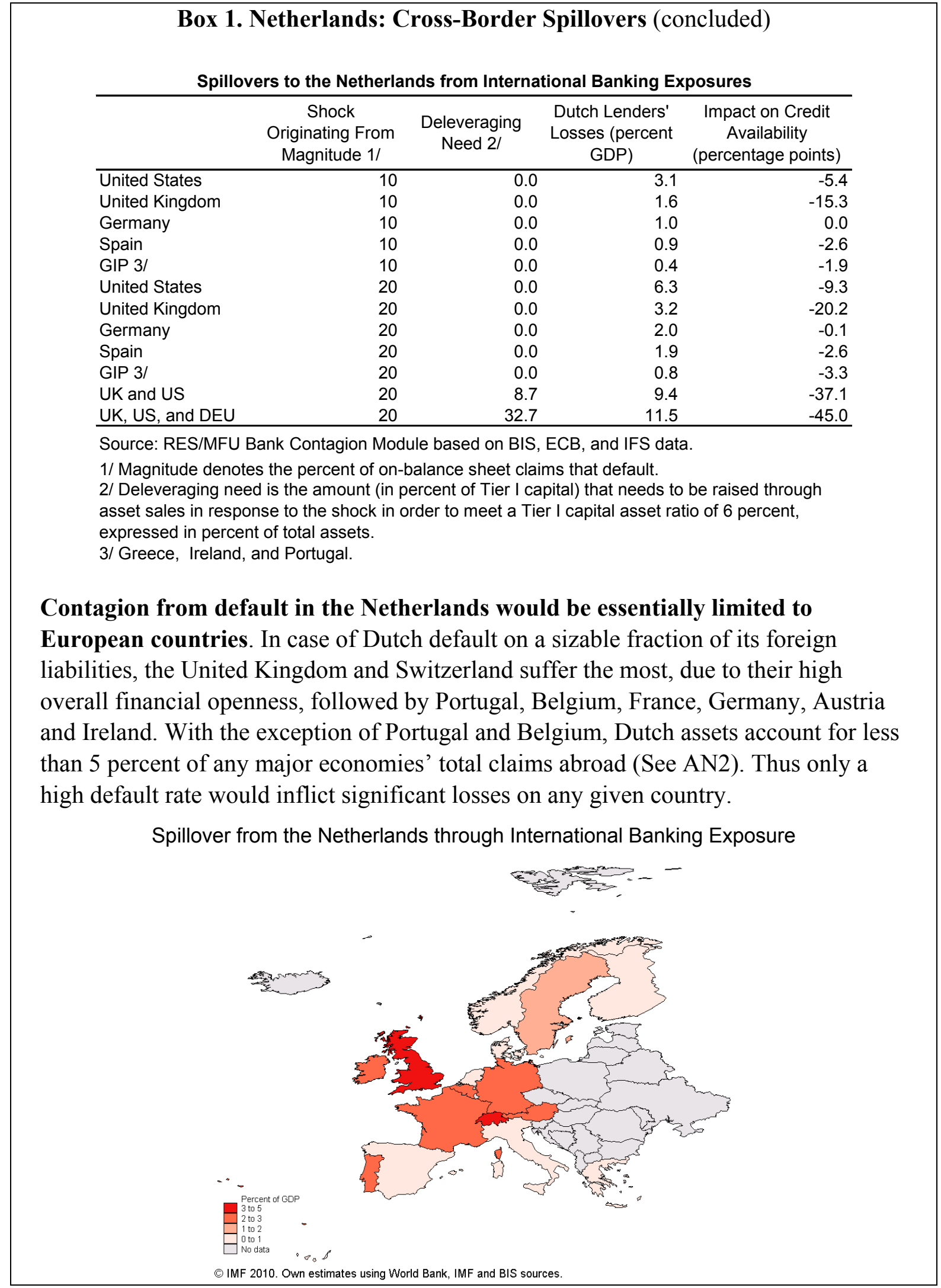




\section{Box 2. Netherlands: Macro-Financial Linkages}

Financial variables had a heavy negative impact on the broader economy during the crisis. Staff estimates the cumulative contribution of deteriorating financial conditions from 2008-09 to GDP growth at $2 \frac{1}{2}-3$ percentage points, based on a Financial Conditions Index (FCI) approach. ${ }^{1}$ A depressed stock market and deteriorated interbank market conditions have fuelled stress in the banking sector via lower asset values and increased costs of refinancing.

Stress in the banking sector, deleveraging, and falling profitability of banks have tightened credit supply conditions. A noticeable excess demand ("credit crunch") materialized during the financial crisis with an estimated peak of 6 percent in 2009Q2, as credit supply fell faster than demand for credit.

The prevalence of excess demand seems to be over. While credit demand remained subdued throughout 2009, credit supply recovered on the back of improved access to capital and a moderation in banking sector stress. Also the initial tightening in credit conditions was mitigated to some extent by an increase in financing via bond markets, where large corporation had ease in obtaining credit.
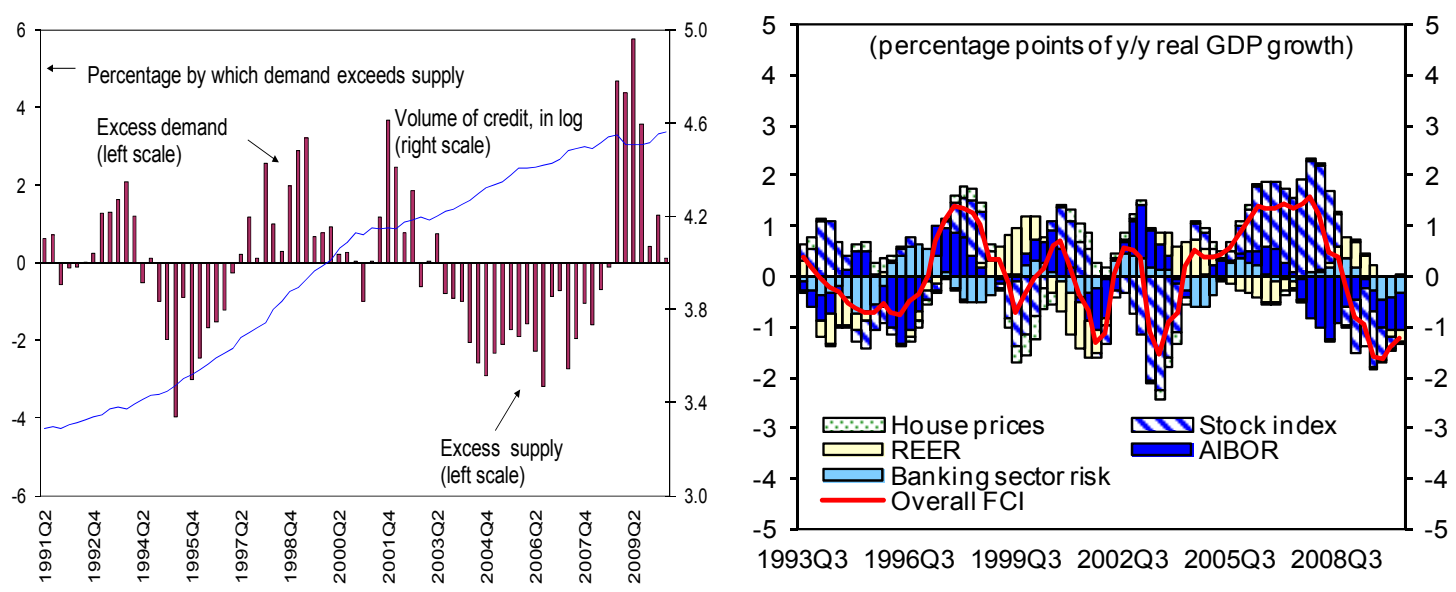

${ }^{1}$ See AN3.

9. Vulnerability to a severe contraction of real estate prices is of medium intensity. Having contracted by 5 percent between mid-2008 and mid-2009, house prices steadied through late 2010, but recently resumed a slow downward drift, amid indications of increased unsold homes. Simple indicators of affordability, though still comparatively high, have improved and stabilized (AN4). There are few signs of overvaluation from econometric models, consistent with relatively modest house price rises compared with other euro area 
economies. Also, the Dutch economy does not display the sort of imbalances that often preceded house price busts, such as rapid credit growth, excessive shifts of expenditures into residential investment, and external imbalances. Additionally, limited land availability reduces downside risks. Commercial real estate prices fell significantly during the crisis, but are stabilizing (Figure 10).

\section{Dutch firms entered the crisis with robust finances but saw a sharp decline in} profitability and are exposed to credit tightening. This is reflected in the still largethough recently declining - number of bankruptcies. Credit growth for nonfinancial corporations has decelerated markedly but remains positive (Box 2). Given comparatively high dependence on bank lending, the Dutch business sector is quite susceptible to a drop in corporate loans or tight credit conditions.
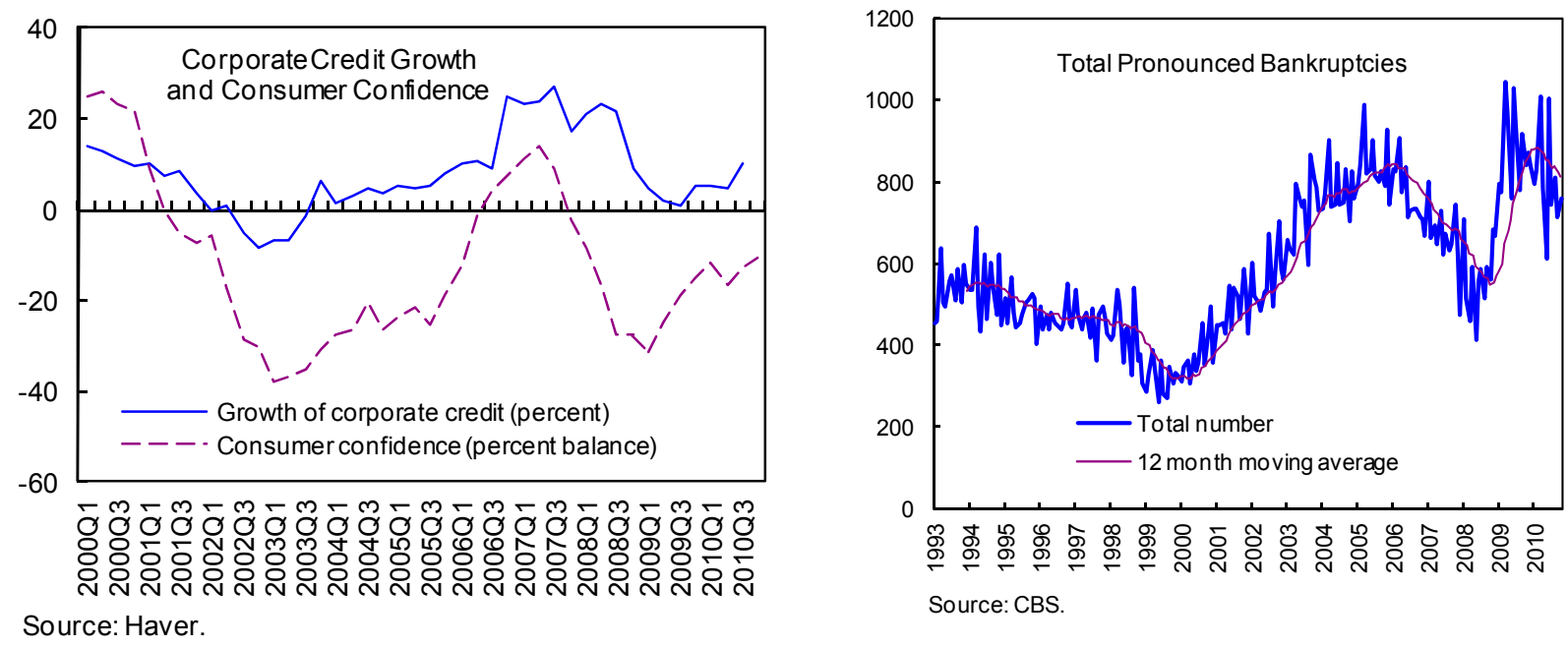

\section{The fiscal position severely deteriorated during the crisis, but is already}

improving (Tables 5a-5b). The general government $(\mathrm{GG})$ headline balance worsened by six percentage points to a deficit of $5 \frac{1}{2}$ percent of GDP in 2009 , reflecting substantial stimulus measures and free operation of automatic stabilizers to stem the impact of the global crisis. However, in 2010 stronger-than-expected tax receipts helped reduce the deficit slightly to $5 \% / 4$ percent of GDP. Discretionary measures over the two years have envisaged: (i) expansion of unemployment alleviation schemes; (ii) infrastructure and housing investment; and (iii) transfers, subsidies, and tax allowances for businesses, especially small- and medium-sized ones. In structural terms, the robust balance worsened by $23 / 4$ percentage points over

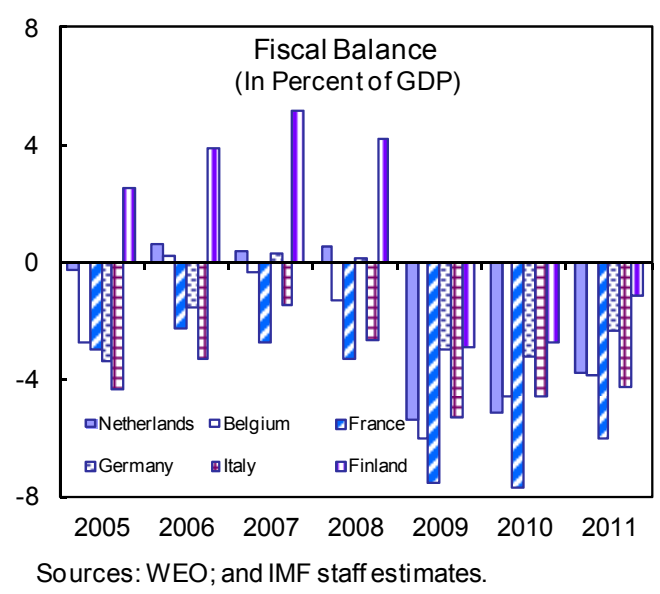


2009-10 compared to 2008 , to a deficit of 5 percent. $^{2}$ Alongside, GG debt has risen to almost 64 percent of GDP in 2010, while population aging remains a challenge for long-term fiscal sustainability.

Evolution of Robust Balance

(In percent of potential GDP)

\begin{tabular}{lrrrrr}
\hline & 2007 & 2008 & 2009 & 2010 & 2011 \\
\hline Structural revenue excl. property income & 42.9 & 43.1 & 42.5 & 42.3 & 42.8 \\
Structural primary expenditure & 44.4 & 45.3 & 47.7 & 47.3 & 47.0 \\
Robust balance & -1.6 & -2.2 & -5.2 & -5.0 & -4.2 \\
$\quad$ Of which: stimulus package & $\ldots$ & $\ldots$ & 0.7 & 0.2 & $\ldots$ \\
$\begin{array}{l}\text { Memorandum item: } \\
\text { Headline fiscal balance (percent of GDP) }\end{array}$ & 0.2 & 0.6 & -5.4 & -5.2 & -3.8 \\
\hline
\end{tabular}

Sources: Ministry of Finance; and IMF staff estimates.

\section{Sizable current account surpluses and a range of indicators suggest adequate} competitiveness (Box 3; Figures 4 and 5). The current account surplus increased significantly to over 7 percent of GDP in 2010 as exports regained their momentum and factor income bounced back from the 2009 lows. The surplus is expected to remain significant over the medium term.

\footnotetext{
${ }^{2}$ Robust balance is the structural primary balance excluding property income (mainly gas revenue).
} 


\section{Box 3. The Netherlands: External Competitiveness}

A range of indicators and the sustained large current account surplus suggest that competitiveness remains comfortable:

- REER measures-using CPI and unit labor cost indices-have fallen significantly in the past year, following appreciation between 2006-09. Much of the drop has reflected the depreciation of the euro, but decelerating wage and price pressures in the aftermath of global recession have also contributed.

- $\quad$ And relative profitability in manufacturing has been broadly stable. Relative profitability is proxied by the ratio of the CPI-based REER to the unit labor cost in manufacturing (ULCM)-based REER. This measure suggests limited trend changes in relative profitability, with a dip in 2007-08 quickly reversed subsequently.

\section{- Export growth has been relatively high and} market share has perked up (Figure 4). With an expansion of around 151/2 percent during 2002-08, export growth has exceeded the euro area average of less than 12 percent. And following the global collapse in trade of 2009, exports rebounded strongly in 2010. However, re-exports (which account for around half of Dutch exports by value) have been important in driving growth of the overall market share.

- Multilaterally consistent CGER methodologies suggest that the real exchange rate is broadly in equilibrium. Despite some divergence, the average of the three approaches indicates that the real exchange rate is largely in line with fundamentals. The medium-term
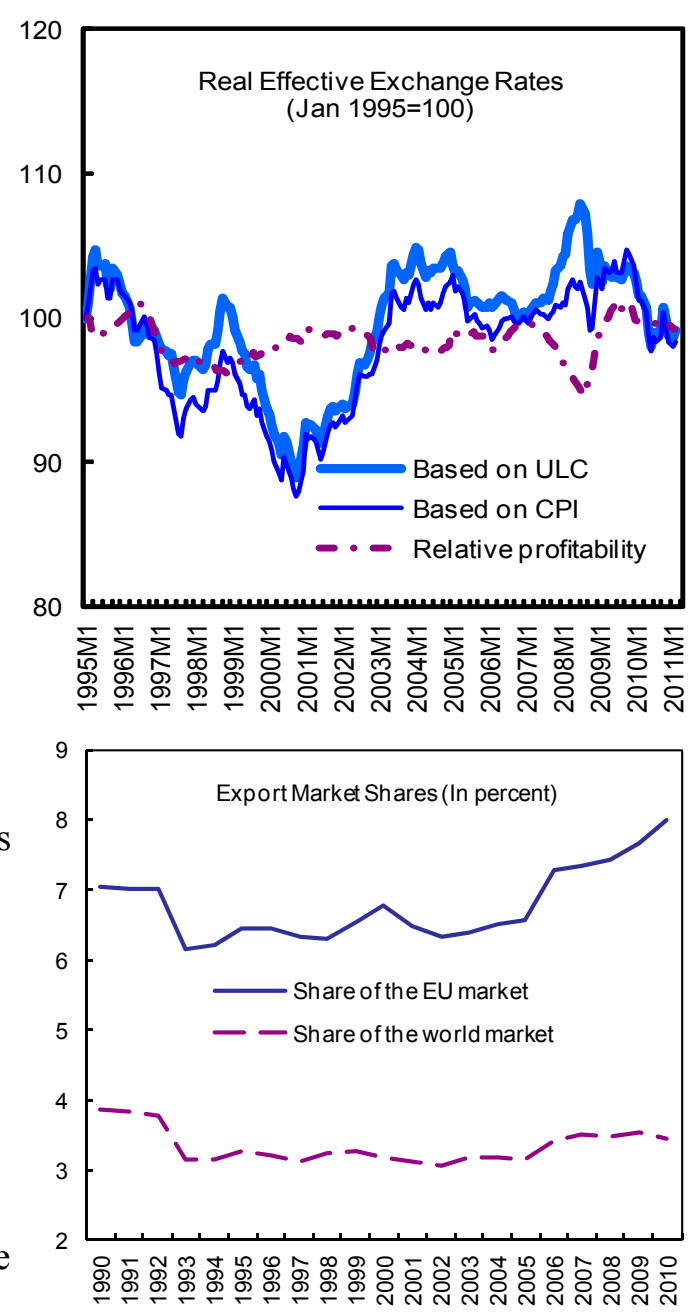
current account (CA) surplus is close to the CA norm, which itself largely reflects the Netherlands' financial center role as well as a high saving rate, influenced by the robust second pillar pension system and large corporate profits arising from international operations. CGER assessments going forward may be affected by crisis-related structural breaks in the relationships underlying the methods.

\section{Estimates of Competitiveness Margin Using CGER Methodologies (Level relative to equilibrium in percent; minus indicates undervaluation)}

\begin{tabular}{|c|c|}
\hline Methodology & \\
\hline Macroeconomic balance approach & 0.8 \\
\hline External sustainability approach & -9.7 \\
\hline Equilibrium real exchange rate approach & -5.8 \\
\hline Memorandum items: & \\
\hline 2010 & 7.1 \\
\hline 2016 & 6.0 \\
\hline CA Norm 2/ & 4.6 \\
\hline $\begin{array}{l}\text { Source: IMF staff estimates. } \\
1 / \text { CGER (Consultatative Group on Exchang } \\
10 \text { and }+10 \text { means the real exchange rate ( } \\
\text { International Monetary Fund, } 2008 \text {, "Exchang } \\
\text { Methologies" (available at www.imf.org). CG } \\
\text { available in March } 2011 \text {. }\end{array}$ & \\
\hline 2/ Macroeconomic balance approach. & \\
\hline
\end{tabular}




\section{Macro Outlook}

\section{Prospects for 2011 and 2012}

13. Following a rebound in 2010, growth is projected to dip slightly in 2011-12. Staff forecast real GDP to expand by $1 \frac{1}{2}$ percent in 2011 and 2012, just lower than in 2010, as base effects dissipate, the pace of exports moderates, and fiscal consolidation commences in most advanced economies. Accordingly, output will remain below potential, though the output gap will continue to decline. Private consumption and construction are expected to remain anemic but investment in machinery is predicted to grow robustly, stimulated by revival in global trade. With a firming recovery, the unemployment rate is anticipated to come down in 2011, while inflation is to stay

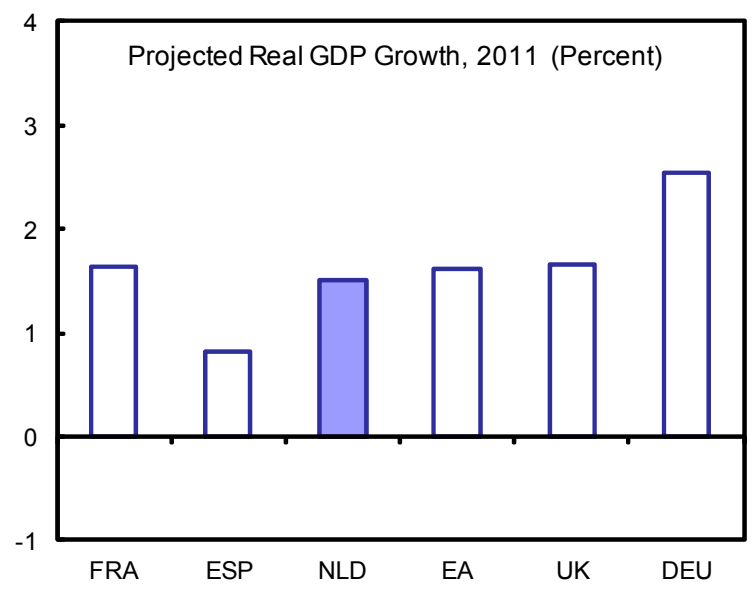
somewhat elevated. The authorities' projections are only slightly more optimistic.

\section{Medium and long-term prospects}

\section{The crisis may have inflicted a permanent output loss, and aging will weigh on} potential growth. The latter is likely running somewhat lower than before the downturn in the near term, owing to the large contraction in investment. It could be hamstrung also by a deceleration in total factor productivity if financing constraints and increased risk aversion curb research and development. Potential growth is however expected to rise to $13 / 4$ percent over the medium term, around the pre-crisis rate, leaving a permanent decline in the level of potential output of $63 / 4$ percent by 2015 (AN5), when the output gap closes. In the longer run, low and slowing population growth together with population aging will squeeze working-age cohorts, while holding back trend productivity. Maintaining potential growth will therefore require boosting labor force participation and reforms to enhance productivity ( $₫ 33-34)$. 
Medium-Term Macroeconomic Framework

\begin{tabular}{lrrrrrrrrr}
\hline & 2008 & 2009 & 2010 & 2011 & 2012 & 2013 & 2014 & 2015 & 2016 \\
\hline Real GDP growth & 1.9 & -3.9 & 1.7 & 1.5 & 1.5 & 1.6 & 1.7 & 1.7 & 1.8 \\
Output gap (percent of GDP) & 2.2 & -2.5 & -1.6 & -0.9 & -0.6 & -0.3 & -0.1 & 0.0 & 0.0 \\
Consumer price inflation (year average) & 2.2 & 1.0 & 0.9 & 2.3 & 2.2 & 2.0 & 1.9 & 1.9 & 1.8 \\
Employment growth & 1.5 & -1.1 & -1.0 & -0.2 & 0.2 & 0.3 & 0.3 & 0.4 & 0.4 \\
Unemployment rate (Eurostat definition) & 2.8 & 3.4 & 4.5 & 4.4 & 4.4 & 4.3 & 4.2 & 4.1 & 4.0 \\
Current account balance (percent of GDP) & 4.3 & 4.6 & 7.1 & 7.9 & 8.2 & 7.8 & 7.2 & 6.6 & 6.0 \\
General government balance (percent of GDP) & 0.6 & -5.4 & -5.2 & -3.8 & -2.7 & -2.1 & -1.8 & -1.3 & -0.6 \\
Robust balance (percent of GDP) & -2.2 & -5.2 & -5.0 & -4.2 & -3.1 & -2.4 & -2.0 & -1.5 & -1.0 \\
General government debt (percent of GDP) & 58.2 & 60.8 & 63.7 & 65.6 & 66.5 & 66.7 & 66.5 & 65.7 & 64.4 \\
\hline
\end{tabular}

Source: Dutch authorities, and IMF staff estimates.

\section{Long-Term Scenario}

Prospects for labor force participation/employment and productivity growth imply a significant drop in per capita income growth.

\begin{tabular}{lrrrrrr}
\hline & 1995-2000 & $2000-05$ & $2005-10$ & $2010-20$ & $2020-30$ & $2030-40$ \\
\hline & & \multicolumn{7}{c}{ (In percent) } \\
Productivity growth 1/ & 1.4 & 1.0 & 0.7 & 1.4 & 1.4 & 1.4 \\
Demographic contribution 2/ & -0.2 & -0.1 & -0.1 & -0.4 & -0.7 & -0.5 \\
Employment rate contribution 3/ & 2.2 & -0.1 & 0.6 & 0.3 & 0.0 & 0.0 \\
GDP per capita growth & 3.5 & 0.8 & 1.1 & 1.3 & 0.7 & 0.9 \\
\hline
\end{tabular}

Sources: WEO; ECFIN: The 2009 Ageing Report; and Staff calculations.

1/ GDP per employed. Projections assume a continuation of the most recent trend.

2/ Change in the share of population 15-64 years.

3/ Employed as a share of population 15-64 years.

\section{Risks}

\section{Risks to the outlook appear tilted} downwards, with heightened uncertainties.

Though house price misalignment is a possible domestic vulnerability, risks stem primarily from external sources, given the Netherlands' extensive trade and financial links. On the downside, they emanate from heightened vulnerability to disruptions in sovereign debt markets, simultaneous fiscal tightening in several advanced European countries, and a lack of progress in resolving global imbalances. On the upside, they originate from unexpectedly positive effects of policy relaxation measures

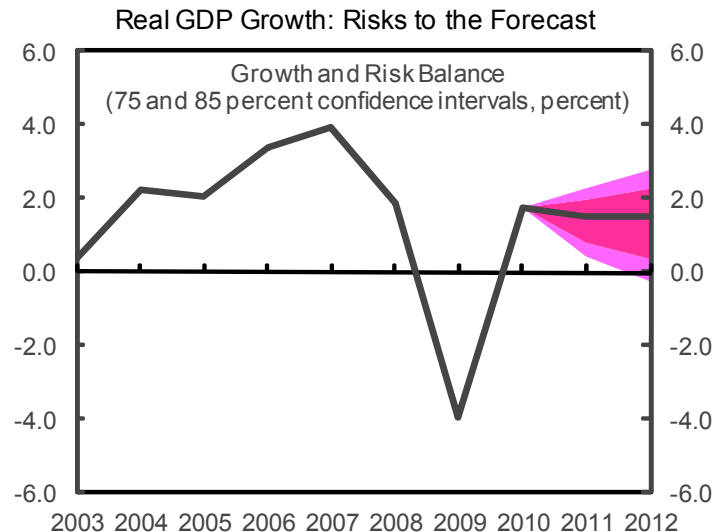

The chart includes the risks to the projections of growth (1.5 percent in 2011 and 1.5 percent in 2012) based on histo rical forecast errors with downside risks n creased by a factor of 20 percent to reflect increased uncertainty.

Source: IMF staff estimates. 
abroad or emerging market growth spurts, which could boost global demand. Specifically:

- Unprecedented sovereign financing is needed globally over a 12-24 month horizon. With investors already jittery, any new shocks in sovereign borrowing markets are likely to prove highly disruptive for already weakened banks and the real economy. Uncertainties could raise risk premia, with negative impact on government debt finances and bank funding costs

- $\quad$ Recent WEO analysis confirms that fiscal consolidation typically has a sizable contractionary impact on growth. Moreover, when several countries in Europe envisage significant simultaneous tightening, the contractionary effects are likely to be sharper and might surpass current estimates. In addition, it may prove difficult to reverse course quickly if the collective retrenchment proves excessive.

- $\quad$ Lack of progress in resolving global imbalances may constrain the global trade outlook and dampen export demand, ultimately depressing activity.

- A larger-than-anticipated impact of the quantitative easing being implemented in the US, not offset by US dollar depreciation, and stronger-than-expected growth in emerging markets could stimulate Dutch exports beyond the central projection. Further depreciation of the euro could have a similar effect.

For each of these factors deviations from the assumed baseline could occur in either direction and impact our central projection for activity accordingly. Nevertheless, the probability of downside occurrences is deemed prevalent - with uncommonly pronounced dispersion - as reflected above. The authorities, though more sanguine on the impact of Europe-wide fiscal retrenchment, broadly shared staff's assessment of the risks.

\section{Policy Discussions}

16. Against this background, the Netherlands must secure the recovery, mitigate lingering vulnerabilities, and start addressing long-term sustainability issues.

- With monetary policy at the limits of its ability to shore up demand, fiscal policy must strike a balance between support of economic activity and prevention of further budget deterioration ( $\mid \mathbf{s} 24-27)$. This argues for a relatively gradual pace of consolidation, in order not to jeopardize the upturn.

Longer term policies should strengthen financial stability, ensure fiscal sustainability, and advance structural reforms to boost potential output. In the financial sector, these include proactive efforts to raise capital to the levels envisaged under Basel III (\$17), implementation of recovery plans for pension funds together with a redefinition of retirement benefits ( $(18)$, strengthening supervisory standards, including by redefinition of rulemaking authority, legal protections, and data reporting ( $\$ 19)$, 
reinforcing macro-prudential supervision ( $\mid \mathrm{s} 20-21)$, and refining crisis resolution procedures and dispositions ( $\$ 22)$. Beyond the medium term objective of substantially reducing the budget deficit, further fiscal adjustment is required to achieve long-term sustainability (\$s28-32). Structural reforms would alleviate the adverse impacts of the crisis and population aging on growth, and facilitate fiscal consolidation ( $\mathbf{q} 33-34)$.

\section{A. Maintaining financial stability}

\section{Bank capitalization and pension fund solvency}

\section{Officials concurred that bank capital buffers appear sufficient to withstand even} severe shocks, though further steps towards meeting Basel III are warranted. FSAP update stress tests, conducted following the methodology used by the Committee of European Bank Supervisors (CEBS) in 2010 for seven banks comprising more than 80 percent of the sector, indicated that no bank has Tier 1 capital falling below 6 percent. Under a more extreme scenario with shocks twice the CEBS size, all banks remain above the current regulatory minimum of 4 percent tier 1 capital and the CEBS 6 percent. Thus, banks appear in a good position to meet the increasingly robust capital requirements under Basel III; but proactive actions to fill any residual gaps - including restraint on dividend payments and raising additional capital — are desirable, especially in light of comparatively high leverage ratios. This will also be helpful to unwind the government's substantial ownership interests in some important financial institutions. Moreover, strong capital and liquidity buffers will facilitate bank restructuring pursuant to EC competition directives.

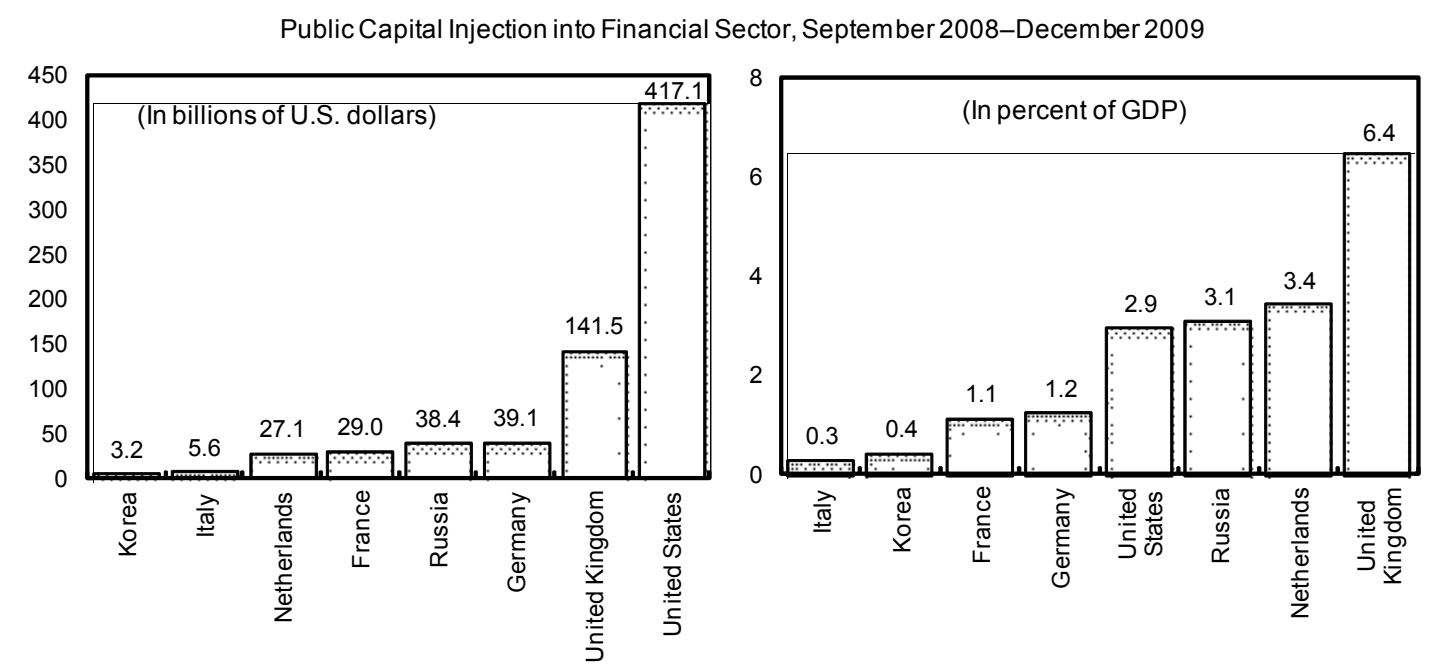

Source: IMF staff estimates based on a G20 Survey.

18. DNB appropriately ordered preparation of recovery plans for several pension funds, but current proposals to reassess benefits are encountering difficulties. With interest rates not expected to return to pre-crisis levels in the near- to medium-term and with improved longevity, pension fund coverage ratios have declined markedly. The authorities 
agreed that a reduction in retirement benefits (through lowering of the replacement rate or further raising of the retirement age) is thus required to re-establish solvency, as they do not consider desirable an increase in contributions. Nevertheless, tripartite discussions among government, employers, and employees on ensuring solvency have been laborious and slowmoving. The opinion of the State Advocate in support of grandfathering existing risk-sharing arrangement has cast further doubts on the proposal. Staff stressed that modifications in risksharing arrangements need to be transparent and communicated effectively to the public to ensure broad social acceptance and suitable changes in household saving.

\section{Supervision and regulation of financial institutions}

19. Supervisory standards are generally high and the authorities have begun taking action in areas for improvement identified by the FSAP update (Table 6). Assessments showed a high degree of compliance with the Basel and other international core principles. Nonetheless, advances are possible in several fields.

- Rulemaking authority is limited and should be enhanced. It presently constrains the ability of supervisors to react swiftly to emerging risks. Both DNB and the AFM can issue sector-wide rules only in areas explicitly mentioned in the law, usually on very technical issues. DNB is also legally restricted from imposing broadly applicable intra-group exposure limits to insurance groups, and its legal authority over financial holding companies is significantly constrained. It also has limited powers to impose resolution tools.

- Concerns about the adequacy of legal protections may have induced DNB to rely excessively on moral suasion for fear of increasing already rampant litigation. The FSAP update recommended giving supervisors legal immunity, except in cases of gross negligence or willful misconduct, in line with practice in neighboring countries.

- $\quad$ Data routinely reported to supervisors no longer have sufficient granularity for full monitoring of financial sector developments and risks - the result of initiatives to reduce administrative burdens on industry. Supervisors are now reviewing data needed for proper execution of their functions and to address identified deficiencies. Greater data dissemination would strengthen market oversight.

- $\quad$ The authorities have made plans for greater supervisory intrusiveness, including thematic inspections of institutions. The FSAP update welcomed these important steps, but emphasized that comprehensive oversight remains essential — not least by on-site inspections and detailed off-site provision of data. Also, the DNB should complement its work on large connected financial institutions (LCFIs) through the Supervisory Colleges with heightened direct understanding of the activities of Dutch financial institutions abroad. Additional resources are likely needed to this end. 
While seeing merit in many of the proposals, the Ministry of Finance considers that the present division between rule-making and implementation powers, and the right of the Minister to take back delegated powers, are consistent with the independence of supervisors and indeed necessary for democratic accountability.

\section{Macro-prudential supervision}

20. The authorities are developing macro-prudential instruments to mitigate risks of recurrence of financial turmoil. Work is underway to develop a comprehensive toolkit for macro-prudential supervision. Instruments relating to the housing market will be key, given the latter's centrality in determining macro-prudential vulnerabilities.

- In this regard, for new mortgages, DNB intends to limit the maximum LTV ratio to 110 percent and require that 50 percent of principal be amortized before expiration, given that LTV ratios in the Netherlands are amongst the highest (Figure 10). In line with the FSAP update, staff welcomed these plans as a useful first step, but noted that they would permit new mortgages with LTV ratios of 110 percent indefinitely, a clear anomaly. Thus, the mission encouraged the authorities to take additional measures, including tighter conditions (closer to international practice) on LTV ratios and minimum principal repayments, setting greater risk weights on high LTV mortgages, and giving DNB the power to impose further LTV restrictions if macro-prudential conditions signal this need.

- The authorities concurred that a key distortion fueling housing market risks is the generosity of MID, which artificially inflates housing prices and the balance sheets of households and banks. Distributional concerns also exist, with MID favoring wealthier borrowers disproportionately. However, abolishing MID in one fell swoop could result in a steep house price decline, damaging aggregate demand through perceptions of diminished wealth, especially if the fall of house prices is accelerated by rising marginal loan rates as a result of deteriorating collateral values. Thus, staff recommended lowering MID gradually, for example through capping it in nominal terms, making a clear statement in this regard soon to eliminate uncertainty. Broader regulatory reform to lessen distortions in the private rental market and in social housing is important, together with reducing the house sales tax, high in international comparison. These distortions severely hampered labor mobility and artificially limit the size of the private rental market. In addition, social housing is not targeted efficiently to low income groups. Although key officials saw merit in the proposals, they noted that a coalition agreement prevented action on MID in the near future, reflecting also concerns about the impact on housing prices.

21. More generally, the FSAP update underscored that broad supervisory discretion and enhanced legal protections should extend to macro-prudential instruments. It would 
also be helpful to assign DNB an explicit objective of ensuring financial stability. In addition DNB should further develop the capability and data for top-down stress testing.

\section{Crisis resolution}

22. Crisis resolution arrangements proved effective during the crisis, and officials are considering steps to strengthen them further. The FSAP update made several proposals in this area. The authorities have already announced plans for upgrading the Deposit Guarantee Scheme, which seem aligned with FSAP update recommendations and were welcomed by staff. Proposals on crisis intervention tools, also broadly consistent with FSAP update advice, have been circulated for discussion.

\begin{tabular}{|l|l|}
\hline \multicolumn{1}{|c|}{ Key FSAP Update Recommendations on Crisis Management and Bank Resolution } \\
\hline Instrument & Recommended Measures \\
\hline Scheme & $\begin{array}{l}\text { Reform the scheme so that it is: (i) ex ante funded, (ii) } \\
\text { authorized to fund bank resolution operations, and (iii) } \\
\text { enjoys depositor preference. }\end{array}$ \\
\hline Crisis Management & $\begin{array}{l}\text { Strengthen the structure by: (i) shifting decision-making } \\
\text { power from the Judiciary to DNB in the context of bank } \\
\text { resolution, and (ii) specifying more clearly the roles of the } \\
\text { Ministry of Finance and DNB in bank resolution. }\end{array}$ \\
\hline Official Financial & $\begin{array}{l}\text { Improve the system by establishing a standing budgetary } \\
\text { authorization for the Government to fund solvency support } \\
\text { in a manner that avoids risk of moral hazard. }\end{array}$ \\
\hline Bank Resolution & $\begin{array}{l}\text { Enhance the framework for bank resolution: } \\
\text { in going concern, by: (i) establishing a single regime for } \\
\text { resolving banks under official control; and (ii) setting } \\
\text { adequate objectives (including financial stability), tasks } \\
\text { and powers for the administrators. } \\
\text { in gone concern, by: (i) introducing a consultative, if not } \\
\text { steering, role for DNB and the AFM throughout the } \\
\text { resolution process to ensure that financial stability } \\
\text { concerns are addressed, and (ii) providing mechanisms } \\
\text { that support the rapid simultaneous transfer of deposits } \\
\text { and assets, and other essential functions (e.g., payment } \\
\text { services). }\end{array}$ \\
\hline
\end{tabular}




\section{B. Fiscal Policy}

\section{Short-Term Fiscal Policy}

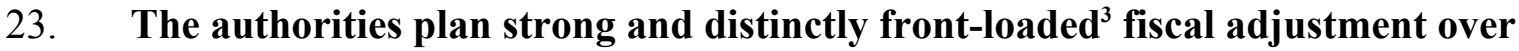

2011-15. Under staff's macro projections, measures envisaged by the new government will reduce the headline deficit to $3 \frac{3}{4}$ percent of GDP in 2011, and 1 1/4 percent of GDP by 2015. Structural tightening of 1 percent of GDP is envisaged for 2011 and 2012, with the pace of retrenchment declining to about $3 / 4$ percent of GDP for 2013, and dropping to $1 / 2$ percent of GDP for 2014 and 2015. The adjustment in 2011 is roughly equally split between revenue increases (with a significant hike in social contributions partly offset by lower taxes) and broad-based expenditure cuts. The authorities stated that their aggressive retrenchment is intended to protect the AAA rating of Dutch sovereign

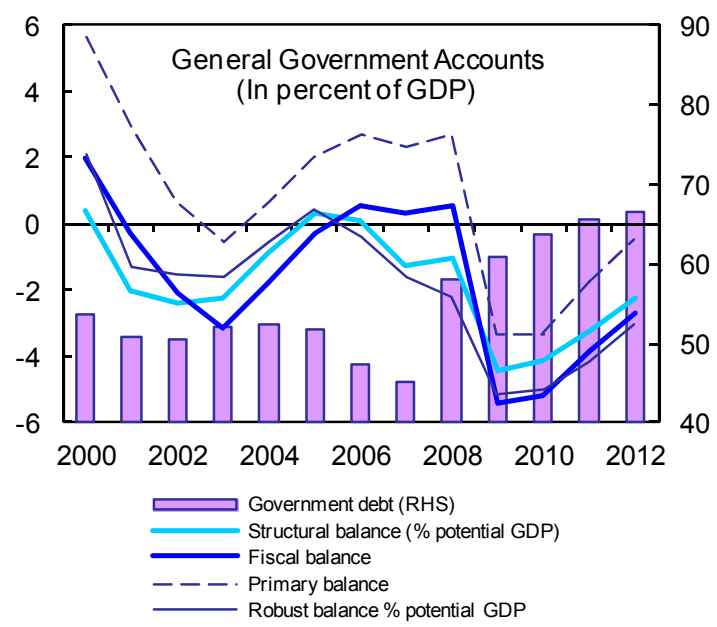

Sources: WEO; and IMF staff estimates bonds and its acceleration was opportune in light of the domestic political cycle.

\section{Staff welcomed the authorities' commitment to consolidation, but advocated flexible handling of the marked front-loading in case of a serious slowdown.}

- $\quad$ The conflicting objectives of reducing the output gap and making progress towards fiscal sustainability ( $\$ 26$ ) have to be balanced. For this reason, in the 2009 Article IV, the Fund supported as prudent the authorities' plan of a gradual structural adjustment (about $1 / 2$ percent of GDP in 2011 and $3 / 4$ percent of GDP thereafter), ${ }^{4}$ aimed at bringing the headline deficit below the SGP ceiling by 2013, while not jeopardizing the recovery (also reflecting the considerations outlined in $\llbracket 29$ ).

\footnotetext{
${ }^{3}$ The accentuated front-loading of the structural adjustment results from the combination of the discretionary retrenchment over 2011-15 with the phasing out of the stimulus provided in 2009-10. The former alone is roughly uniformly distributed over time.

${ }^{4}$ Specifically, a structural retrenchment of $3 / 4$ percent of GDP per year (a bit less in 2011) was sought, until the headline deficit fell below 3 percent of GDP in 2013. Beyond 2013, tightening would take place at a more measured pace, with a view to close progressively the sustainability gap.
} 
- $\quad$ The tightening now envisaged is much more front-loaded than that previously scheduled, and both the authorities and staff have correspondingly incorporated some additional contractionary impact on short-term growth in their central projections. At the same time, the accelerated adjustment is expected to benefit fiscal sustainability considerably. Nevertheless, historical experience indicates that negative effects on demand from budget consolidation are likely to be higher when monetary policy is not able to accommodate tightening, as is currently the case. Staff analysis also suggests that spillovers to the Netherlands from the concomitant fiscal retrenchment in Europe are sizable (AN2), complicating options for tempering the policy if an unexpected slowdown occurs. While both these factors have been taken into account in the

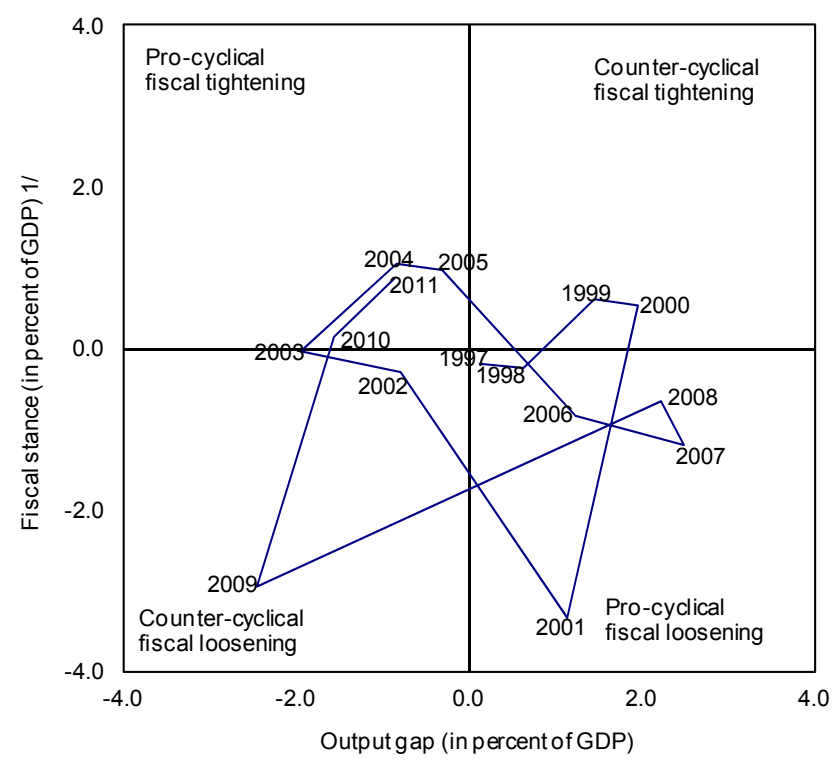

$1 /$ Fiscal stance is measured by the change in the robust balance. baseline scenario, a significant downside risk is that the contractionary impact of simultaneous fiscal tightening in several advanced European countries could prove sharper than currently estimated.

- In addition, despite a substantial sustainability gap, there is no immediate fiscal credibility issue, and debt is lower than in many advanced economies; hence pressure from markets with regard to Dutch financing requirements is negligible. Furthermore, evidence of bubbles in fiscal revenues that could justify more substantive early tightening is scant (AN6).

- $\quad$ These considerations suggest that flexibility in the implementation of the planned fiscal adjustment is both possible and desirable should economic outcomes be significantly worse than anticipated, so as not to exacerbate downside risks for growth prospects in the near-term. To moderate adverse impacts on aggregate demand, in any case, it might be preferable to substitute part of the headline tightening with structural measures (such as increasing further the retirement age), which improve significantly fiscal sustainability, but impact only modestly the government balance in the short-run. 
Summary of Measures in the Government's Fiscal Consolidation Program 1/ (in percent of GDP)

\begin{tabular}{|c|c|c|c|c|c|c|}
\hline & 2011 & 2012 & 2013 & 2014 & 2015 & Structural $2 /$ \\
\hline Total & 0.5 & 0.6 & 0.6 & 0.6 & 0.5 & 3.6 \\
\hline Improvement in revenue from revision in macro forecast in Sept 2010 & 0.2 & 0.1 & 0.1 & 0.0 & 0.0 & 0.5 \\
\hline Subtotal & 0.2 & 0.4 & 0.5 & 0.6 & 0.5 & 3.1 \\
\hline Reversal of increase in healthcare personal contribution & 0.0 & 0.0 & -0.1 & 0.0 & 0.0 & -0.2 \\
\hline $\begin{array}{l}\text { Spending reductions } \\
\text { of which: }\end{array}$ & 0.3 & 0.6 & 0.6 & 0.6 & 0.7 & 3.7 \\
\hline Smaller government & 0.0 & 0.2 & 0.2 & 0.2 & 0.3 & 0.9 \\
\hline Grants & 0.0 & 0.0 & 0.0 & 0.0 & 0.0 & 0.4 \\
\hline Immigration and integration & 0.0 & 0.0 & 0.0 & 0.0 & 0.0 & 0.0 \\
\hline International cooperation & 0.1 & 0.1 & 0.0 & 0.1 & 0.0 & 0.3 \\
\hline Wage moderation & 0.1 & 0.0 & 0.0 & 0.0 & 0.0 & 0.1 \\
\hline Income transfers & 0.0 & 0.2 & 0.2 & 0.1 & 0.1 & 1.3 \\
\hline Education & 0.0 & 0.1 & 0.1 & 0.0 & 0.0 & 0.2 \\
\hline Health care (long-term care) & 0.0 & 0.0 & 0.0 & 0.0 & 0.1 & 0.1 \\
\hline Health care (curative care) & 0.0 & 0.0 & 0.0 & 0.0 & 0.2 & 0.3 \\
\hline Other & 0.0 & 0.0 & 0.0 & 0.0 & 0.0 & 0.1 \\
\hline Spending increases & -0.1 & -0.2 & -0.1 & -0.1 & -0.1 & -0.7 \\
\hline Tax and social insurance contributions & 0.1 & 0.1 & 0.1 & 0.1 & -0.1 & 0.3 \\
\hline
\end{tabular}

Source: Dutch authorities.

1/ Excludes the impact of the withdrawal of the discretionary stimulus measures of 2009-10

2/ Overall structural impact. Includes the effect of measures taken during 2011-15 but with impact that extends beyond 2015

\section{In particular, automatic stabilizers ought to be allowed to operate freely and} contingency plans developed to moderate the adjustment, should the recovery stall. Staff argued that unhindered operation of automatic stabilizers would require excluding unemployment benefits from expenditure ceilings. Moreover, unexpected serious setbacks to the recovery that cause the headline deficit to rise substantially above targeted levels should not trigger further discretionary retrenchment - as envisaged under the government program. Staff also advised that contingency plans be prepared beforehand to ease the envisioned fiscal tightening, so that prompt action would be possible, in the event that (i) domestic growth falters markedly below envisaged rates; or (ii) high frequency indicators and adverse developments in international financial markets and economic activity abroad suggest that the recovery is coming to a standstill.

\section{The authorities generally concurred, but stressed that only a very severe shock} to the recovery would warrant relaxation of their fiscal adjustment plans. In their view, automatic stabilizers on revenues were sufficiently large, limiting need for discretionary action. Thus, discretionary action would only be justified by the clear and present danger of another major recession. Staff noted however that, under existing fiscal rules, the operation of automatic stabilizers would be capped, if the deficit exceeded the plan by 1 percent of GDP. The authorities were also concerned that public articulation of contingency plans could lead to a push for more spending even if the recovery continues. 


\section{Medium-Term Fiscal Policy and Sustainability}

\section{The long-term GG position remains weak (AN7 and AN8), reflecting in part the} impact of the crisis. Staff estimates a fiscal sustainability gap of $7 \frac{1}{2}$ percent of GDP. ${ }^{5,6}$ Despite comparatively low initial debt, several crisis-related factors have inflated the sustainability gap: (i) the marked structural fiscal relaxation in 2009-10; (ii) large operations in support of the financial sector, which have not increased the deficit but added to public debt; and (iii) weaker potential output. In addition, aging-related spending is expected to increase by nine percent of GDP over 2011-60, on account of pensions, health- and old-age care.

\section{Accordingly, there was agreement that consolidation will need to continue}

beyond 2015 to ensure fiscal sustainability. Reasonable calibration of the tradeoff between output stabilization and fiscal sustainability, broadly consistent with the Netherlands' medium-term pledges under the SGP, suggests that adjustment of about $3 / 4$ percent of GDP per annum would be desirable and close the sustainability gap by 2021 . As noted above, though, the authorities now aim for a notably more frontloaded consolidation in 2011-12, albeit with a slower pace of tightening over the medium term. In any case, staff argued, supporting measures beyond 2011 should be adopted promptly.

\footnotetext{
${ }^{5}$ This is the improvement in the GG robust balance after 2011 compared with the no-measures path needed to attain long-term stability of public debt as a share of GDP. The sustainability indicator used here is based on the intertemporal budget constraint (see AN7), and is consistent with the S2 measure of the EC (Sustainability Report 2009, pp148-49). The sustainability gap — evaluated as of 2012 - has decreased from 8 percent of GDP in IMF Country Report No. 10/34, primarily reflecting the strong consolidation of 2011. This estimate assumes that the outlays for the financial sector bailout are fully recouped. Without recovery of these outlays the sustainability gap increases to $73 / 4$ percent of GDP.

${ }^{6}$ The authorities' latest estimates of the sustainability gap are significantly smaller because they incorporate the corrective adjustment planned throughout 2015, although measures have been enacted only for 2011, and allow for a putative long-term boost to consumption tax revenues from population aging (AN7).
} 
Netherlands: Fiscal Sustainability, 2012-60 1/

(in percent of GDP)
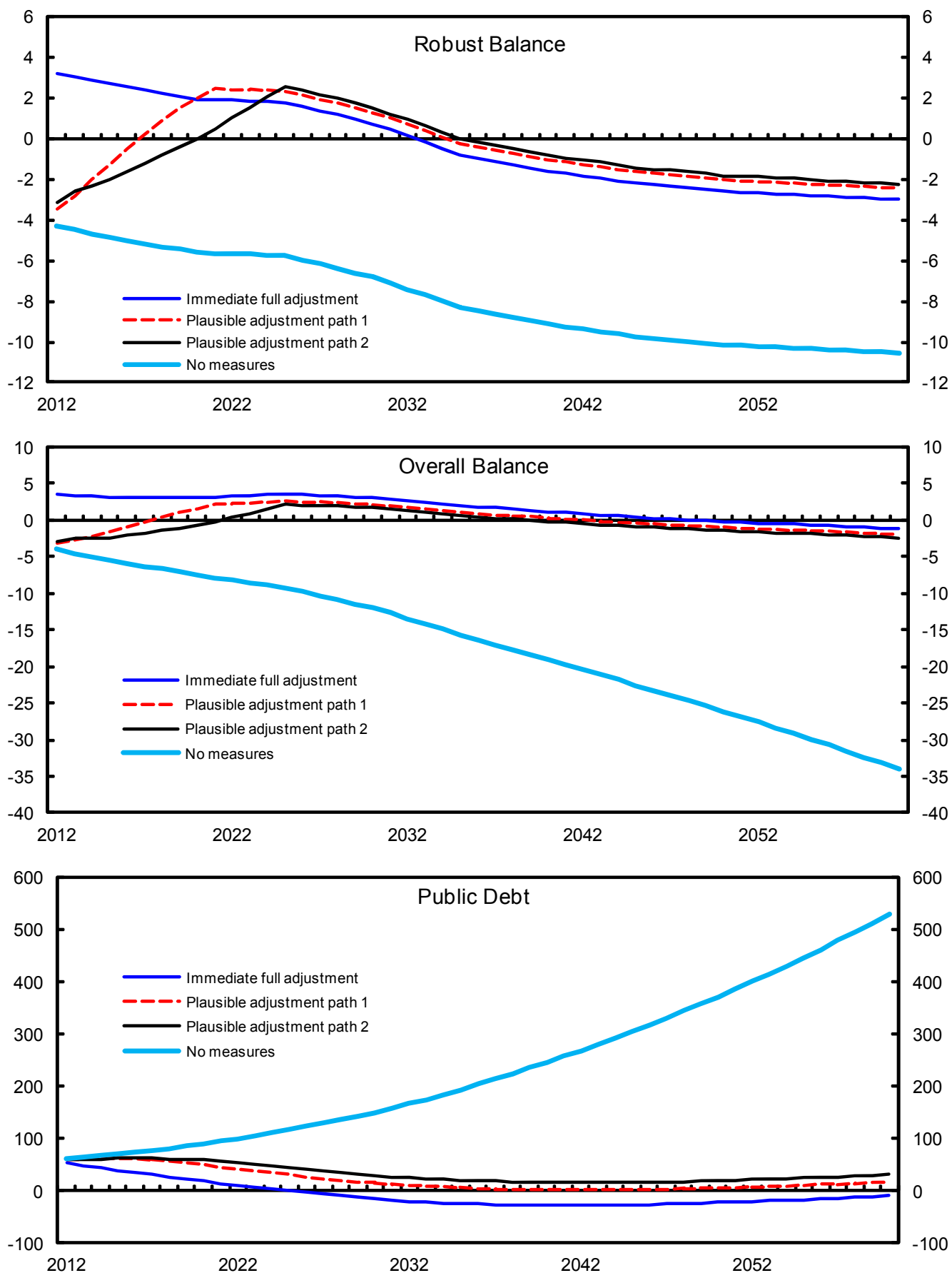

Sources: CPB: Ageing and the Sustainability of Dutch Public Finances (2006), ECFIN: The 2009 Ageing Report, and Staff calculations.

1/ Plausible adjustment path 1 is somewhat less ambitious than authorities' adjustment path in the short run, but envisages stronger consolidation thereafter such that the sustainability gap is closed in 2021. This also corresponds to the variable weights scenario in Table 7-1. Plausible adjustment path 2 is consistent with the authorities' adjustment path up to 2015 , and further assumes that consolidation continues at a pace of $1 / 2$ percent of GDP until the sustainability gap is closed in 2025 . 


\begin{tabular}{|c|c|c|c|c|c|c|c|c|c|c|c|}
\hline \multicolumn{12}{|c|}{ Illustrative Optimal Annual Fiscal Adjustment Paths Under Quadratic Preferences 1/ } \\
\hline Loss Function Weights $2 /$ & & 2012 & 2013 & 2014 & 2015 & 2016 & 2017 & 2018 & 2019 & 2020 & 2021 \\
\hline \multirow[t]{3}{*}{ Alpha $=0.5$ Gamma $=0.5$} & Annual consolidation & 5.2 & 0.9 & 0.6 & 0.4 & 0.2 & 0.2 & 0.1 & 0.1 & 0.0 & 0.0 \\
\hline & Sustainability gap & 2.5 & 1.6 & 1.1 & 0.7 & 0.4 & 0.3 & 0.2 & 0.1 & 0.1 & 0.1 \\
\hline & Underlying output gap 4/ & -3.8 & -2.5 & -1.6 & -1.1 & -0.7 & -0.5 & -0.3 & -0.2 & -0.1 & -0.1 \\
\hline \multirow[t]{3}{*}{ Alpha $=0.0$ Gamma $=1.0$} & Annual consolidation & 7.7 & 0.0 & 0.0 & 0.0 & 0.0 & 0.0 & 0.0 & 0.0 & 0.0 & 0.0 \\
\hline & Sustainability gap & 0.0 & 0.0 & 0.0 & 0.0 & 0.0 & 0.0 & 0.0 & 0.0 & 0.0 & 0.0 \\
\hline & Underlying output gap 4/ & -5.4 & -2.7 & -1.3 & -0.7 & -0.3 & -0.2 & -0.1 & 0.0 & 0.0 & 0.0 \\
\hline \multirow[t]{3}{*}{ Alpha $=1.0$ Gamma $=0.0$} & Annual consolidation & -0.7 & 0.0 & 0.0 & 0.0 & 0.0 & 0.0 & 0.0 & 0.0 & 0.0 & 0.0 \\
\hline & Sustainability gap & 8.3 & 8.4 & 8.6 & 8.7 & 8.8 & 9.0 & 9.1 & 9.3 & 9.4 & 9.5 \\
\hline & Underlying output gap 4/ & 0.0 & 0.0 & 0.0 & 0.0 & 0.0 & 0.0 & 0.0 & 0.0 & 0.0 & 0.0 \\
\hline \multirow[t]{3}{*}{ Alpha $=0.9$ Gamma $=0.1$} & Annual consolidation & 0.8 & 0.6 & 0.6 & 0.5 & 0.5 & 0.5 & 0.4 & 0.4 & 0.4 & 0.3 \\
\hline & Sustainability gap & 6.8 & 6.3 & 5.8 & 5.3 & 4.9 & 4.5 & 4.2 & 3.9 & 3.5 & 3.3 \\
\hline & Underlying output gap 4/ & -1.0 & -0.9 & -0.8 & -0.8 & -0.7 & -0.7 & -0.6 & -0.6 & -0.5 & -0.5 \\
\hline \multicolumn{12}{|l|}{ Memorandum item: } \\
\hline \multirow[t]{3}{*}{ Variable weights 3 / } & Annual consolidation & 0.8 & 0.8 & 0.9 & 0.9 & 0.9 & 0.8 & 0.8 & 0.7 & 0.6 & 0.5 \\
\hline & Sustainability gap & 6.8 & 6.0 & 5.2 & 4.3 & 3.4 & 2.6 & 1.8 & 1.1 & 0.5 & 0.0 \\
\hline & Underlying output gap 4/ & -1.0 & -1.0 & -1.1 & -1.2 & -1.2 & -1.1 & -1.1 & -1.0 & -0.9 & -0.8 \\
\hline
\end{tabular}

Source: IMF staff calculations.

1/ Initial sustainability gap (given no consolidation from 2012 onward) $=7.5$ percent of GDP; Initial output gap (in 2011) = -1.0 percent of GDP: fiscal multiplier is taken to be 0.6 ; autoregressive parameter for output gap (lambda) is taken to be 0.5 ; nominal interest rate $=5$ percent; nominal GDP growth rate $=3.4$ percent.

2/ Alpha is the weight on the output gap, while gamma is the weight on the sustainability gap.

$3 /$ Alpha is assumed to decline over time from an initial value of 0.9 to zero over a 10 -year period, while Beta rises at the same pace from an initial value of 0.1 . This scenario corresponds to "Plausible adjustment path 1" in the Netherlands: Fiscal Sustainability, 2012-60 textchart.

4/ The underlying output gap is not directly comparable with the output gap in staff's WEO projections, as the WEO projections assume that other effects (including confidence e.t.c) will provide some offset to the negative impact of fiscal tightening, such that the output gap closes in 2016.

These other effects could be modeled by introducing an exogenous term into the equation governing the evolution of the underlying output gap.

\section{Measures to Achieve Sustainability}

\section{The consensus was that scope for increasing the tax burden is limited (Figure} 11), thus expenditure retrenchment has to play a key role in adjustment. Expenditurebased consolidations have generally been more successful, based on international evidence. Moreover, given international competition to lower corporate taxation and relatively large tax wedges on earned income which discourage work, direct tax rates have little upward room. The mission therefore advised that focus on the revenue side should be on base broadening for example curtailing generosity of MID ( $₫ 31$ — — and a shift from labor to less distortionary taxation of consumption and property, including by reducing the number of items on reduced VAT rates. Concerning outlays, the priority should be reducing the impact of aging on fiscal expenditures, through increases in the effective retirement age and measures to restrain growth in demand for health- and long-term care (Table 7).

\section{In this regard, the authorities considered that the fiscal correction's focus on outlays was apt, though staff expressed concern at its limited structural content. The} deep broad-ranging cuts in expenditure over 2011-15 envisage restraining growth of public wages, curtailing the size of the civil service, slowing down health care costs, and reducing grants and transfers. Staff stressed that the ambitious fiscal objectives throughout 2015 should not come at the expense of progress in structural reforms with beneficial budgetary 
implications, which seem to have been given limited prominence in the new government's program.

31. Staff argued that eliminating the costly MID scheme would benefit both growth and the budget in the long run, but should be implemented gradually. The implicit subsidy to homeowners represents around 7 percent of total revenues. Phasing out the deduction could have considerable long-run benefits. A gradual reduction that allows households time to adjust and does not affect existing mortgage contracts greatly is desirable. Nonetheless, to realize the benefits of the reform quickly, a credible commitment to eventual elimination or radical curtailment of the subsidy is needed (AN9 and $\lceil 20$ ). However, despite much public discussion, the momentum to tighten the MID regime appears to have lost steam.

\section{Structural Reforms}

32. The authorities agreed that, with a stagnating population amid aging pressures, policies need to encourage greater work effort to maintain potential growth (Table 8).

- $\quad$ The participation rate of the elderly is relatively low by international standards and the effective average retirement age is close to 4 years below the statutory rate of 65 years, while hours worked by women are low. Officials are considering steps to:

(i) increase the minimum age - together with steeper penalties — for early retirement; and (ii) further curtail disincentives in taxation or social benefits to longer working hours by females. It had been envisaged to lift the statutory retirement age by two years to 67 , but this has now been reduced to 66 . The authorities noted that that a majority in parliament — not coinciding with that supporting the government—could vote for linking the retirement age to life expectancy, a measure in line with staff recommendations.

- Unemployment benefits are fairly generous and may discourage job search, lifting the duration of unemployment. Lowering the benefits and limiting their length, however, are not included in the government program.

33. Similarly, fostering research and development (R\&D) and combating traffic congestion would enhance productivity and thus also growth.

- Gross domestic expenditure on R\&D, public and private, is fairly modest. More support for R\&D could not only fuel productivity through innovation, but also improve incentives for higher education by building up demand for top-skilled workers.

- Various estimates put the Netherlands among the countries with the highest costs of congestion. Stepped up investment in roads and railways, which would require some 
relaxation of strict zoning regulations, road pricing, and opening the transportation sector to more competition could alleviate congestion and thus spur productivity.

The authorities are considering options in these areas. In particular, their Europe 2020 plan does focus on increasing efficiencies in current arrangements.

Model Based Estimates of Impacts of Relevant Structural Policy Reforms on Growth 1/

\begin{tabular}{|c|c|c|}
\hline Policy & Definition of shock & Effect \\
\hline y retirement & +1 year & +0.3 percent GDP per capita \\
\hline yment benefits, re & ercentage points & + 3 percent GDP per capita \\
\hline Business R\&D & $+1 p$ & +0.13 percent TFP growth \\
\hline Public R\&D & +1 percent & +0.17 percent TFP growth \\
\hline Investment in traffic infrastructure & - 10 percent congestion & +0.22 percent GDP \\
\hline
\end{tabular}

Source: OECD

1/ Assessments of the impact of structural reform on growth or GDP should be taken with great caution.

\section{Staff Appraisal}

34. The Dutch economy is on the mend, but the recovery still frail. The upturn has been fueled by strong exports. Unemployment has risen only modestly and is the lowest in Europe, mainly because strong pre-crisis profitability coupled with the fear of future labor shortages from population aging have kindled labor hoarding by firms. With output still well below potential, inflation has remained subdued, even if it is now picking up because of rising oil and commodity prices. Wages though are under control and external competitiveness is adequate. A subdued continuation of the recovery is projected for 201112 , with output remaining below potential and modest inflation. Risks - primarily from external sources - appear tilted downwards. The crisis has also led to a permanent loss of output aggravating the problems posed by aging, not least to fiscal sustainability.

\section{Lingering risks require continued vigilance on bank capital and liquidity, given} also increasingly robust regulatory requirements. FSAP update stress tests outcomes and spillovers are benign, with banks' capital and liquidity positions able to withstand even quite severe scenarios. Nevertheless, with relatively high leverage ratios and tighter capital standards to be phased in under Basel III, proactive measures are desirable to prevent emergence of any capital or liquidity shortcomings. Such steps will also smooth the phasing out of government equity from intervened banks and bank restructuring.

36. It is crucial to address promptly housing market vulnerabilities and distortions. Given heavy exposure of the financial system to the housing market, a determined response to the buildup of vulnerabilities there is warranted. Authorities' plans to limit the maximum LTV ratio and impose a fractional minimum principal repayment are welcome, but insufficient. Further tightening of LTV ratios and minimum principal repayments, setting greater risk weights on high LTV mortgages, and giving DNB the authority to impose further 
LTV restrictions if required would be useful. Moreover, a clear and credible statement that MID will be gradually reduced should be made to eliminate uncertainty and minimize the possible impact on the housing market. This should be accompanied by deep regulatory reform of the housing sector and a cut of the house sales tax.

\section{Despite improved supervisory practices, the effectiveness of supervision and} crisis resolution mechanisms can be further buttressed. Concerns include rule-making authority and legal protections of supervisors; adequacy of data reporting requirements; banking supervision culture; resource limitations; and the crisis resolution framework. In particular, DNB and the AFM should be provided with broad supervisory discretion over macro-prudential instruments, in line with their respective responsibilities, and a single regime created for resolving banks under official control. Welcome efforts are being made to address these issues, but further early and sustained action in these areas is needed, with a focus on intensifying and coordinating supervision of large international financial institutions and improving reporting requirements. The insurance sector warrants careful monitoring too, given its tarnished reputation, and the financial pressures under which it is operating.

\section{To restore pension fund viability, second-pillar pension benefits should be} recalibrated. Persistently low interest rates and rising longevity have put pressure on the coverage ratios of many funds. Lower retirement benefits (including through further raises of the retirement age) or higher contributions are thus required. The public should be made fully aware of risk-sharing modifications, not least to induce fitting changes in saving behavior.

\section{The planned strong fiscal adjustment should be implemented flexibly in case of a sharp and prolonged slowdown to prevent harming the recovery. While it remains} appropriate to close the fiscal sustainability gap within 10-15 years, the conflicting objectives of reducing the output gap and making progress towards fiscal sustainability have to be balanced in the short run. The front-loaded adjustment is expected to benefit fiscal sustainability considerably, with potential positive effects on consumer and investor confidence on the long-run prospects of the economy. Nevertheless, there are no immediate concerns about Dutch fiscal credibility. Moreover, a significant downside risk is that the contractionary impact of simultaneous fiscal tightening in several advanced European countries could prove sharper than currently estimated, particularly since monetary policy is at the limit of its ability to provide stimulus. Thus, if the recovery were to stall, automatic stabilizers ought to function unhindered and contingency plans developed to moderate the adjustment.

\section{Measures that directly reduce the impact of aging on public expenditures or} broaden the tax base must be a key plank of adjustment. Expenditure-based consolidations have generally been more successful than tax-centered ones and there is not much scope to raise tax rates. Therefore, revenues could only be augmented by expanding the base - for example by limiting MID, a large tax expenditure - and a further move away from labor to less distortionary indirect taxation. Concerning fiscal outlays, the priority is to 
increase the effective retirement age and to restrain growth in demand for and costs of healthand long-term care, also by raising co-payments and user fees. In general, renewed emphasis should be placed on structural fiscal reform efforts.

\section{To maintain potential growth amid a stagnating population and aging} pressures, policies should encourage greater work effort and productivity. Apart from increasing the retirement age, labor market reforms should overhaul tax and benefit systems to curtail disincentives to full-time female and elderly work. Excessive generosity of unemployment benefits should be pared down not to discourage job search and prolong unemployment spells. Fostering research and development (R\&D) expenditure, which is quite limited, would enhance productivity. Less strict zoning regulations, more competition in the transport sector together with an upgrade of its infrastructure, and extension of road pricing could counter congestion and also stimulate productivity.

42. It is recommended that the next Article IV consultation be held on the standard 12-month cycle. 
Table 1. Netherlands: Basic Data

Land area (2007)

Population (2006)

Population characteristics and health:

Life expectancy at birth (2006)

Fertility rate (2006)

Infant mortality rate (2006)

Population per sq. km. of land area (2006)

National accounts 2009

Private consumption

Public consumption

Gross fixed investment

Stockbuilding

Exports of goods and nonfactor services

Imports of goods and nonfactor services

Nominal GDP (at market prices)
41.5 thousand sq. $\mathrm{km}$.

16.3 million

76.4 (male), 81.7 (female)

1.7 children/woman

4.96 per 1,000 live births

483 persons

(In billions of euros)

(In percent of GDP)

262.6

162.7

108.9

$-3.5$

395.9

354.6

572.0

45.9

28.4

19.0

$-0.6$

69.2

62.0

100.0

\begin{tabular}{|c|c|c|c|c|c|c|c|c|c|}
\hline & & & & & & & Proj. & Proj. & Proj. \\
\hline & 2004 & 2005 & 2006 & 2007 & 2008 & 2009 & 2010 & 2011 & 2012 \\
\hline \multicolumn{10}{|c|}{ (Annual percentage change; unless otherwise indicated) } \\
\hline \multicolumn{10}{|l|}{ National accounts (constant prices) } \\
\hline Private consumption & 1.0 & 1.0 & $-0.31 /$ & 1.8 & 1.1 & -2.5 & 0.4 & 1.0 & 0.9 \\
\hline Public consumption & -0.1 & 0.5 & $9.51 /$ & 3.5 & 2.5 & 3.7 & 1.5 & -1.1 & -0.8 \\
\hline Gross fixed investment & -1.6 & 3.7 & 7.5 & 5.5 & 5.1 & -12.7 & -4.9 & 2.4 & 2.8 \\
\hline Total domestic demand & 0.5 & 1.4 & 4.0 & 3.2 & 2.3 & -4.2 & 0.8 & 0.3 & 0.7 \\
\hline Exports of goods and nonfactor services & 7.9 & 6.0 & 7.3 & 6.4 & 2.8 & -7.9 & 10.9 & 6.0 & 5.0 \\
\hline Imports of goods and nonfactor services & 5.7 & 5.4 & 8.8 & 5.6 & 3.4 & -8.5 & 10.6 & 5.3 & 4.5 \\
\hline Net foreign balance 2/ & 1.9 & 0.9 & -0.5 & 1.0 & -0.2 & -0.2 & 1.1 & 1.1 & 0.9 \\
\hline Gross domestic product & 2.2 & 2.0 & 3.4 & 3.9 & 1.9 & -3.9 & 1.7 & 1.5 & 1.5 \\
\hline Output gap (in percent of potential output) & -0.8 & -0.3 & 1.2 & 2.5 & 2.2 & -2.5 & -1.6 & -0.9 & -0.6 \\
\hline \multicolumn{10}{|l|}{ Prices, wages, and employment } \\
\hline Consumer price index (HICP) & 1.4 & 1.5 & 1.7 & 1.6 & 2.2 & 1.0 & 0.9 & 2.3 & 2.2 \\
\hline GDP deflator & 0.7 & 2.4 & 1.8 & 1.8 & 2.4 & -0.2 & 1.4 & 1.5 & 1.4 \\
\hline Hourly compensation (manufacturing) & 1.6 & 0.9 & 1.8 & 1.7 & 3.7 & 2.9 & 1.2 & 1.5 & 1.5 \\
\hline Unit labor costs (manufacturing) & -1.5 & -0.8 & -0.5 & 0.2 & 3.3 & 5.8 & -1.6 & -0.2 & 0.2 \\
\hline Employment & -0.9 & 0.5 & 1.7 & 2.5 & 1.5 & -1.1 & -1.0 & -0.2 & 0.2 \\
\hline Unemployment rate (in percent) & 4.6 & 4.7 & 3.9 & 3.2 & 2.8 & 3.4 & 4.5 & 4.4 & 4.4 \\
\hline \multicolumn{10}{|l|}{ Personal sector } \\
\hline Real disposable income & 2.4 & 1.0 & $-0.61 /$ & 4.4 & 2.8 & -10.6 & 0.1 & -0.4 & 0.1 \\
\hline Household savings ratio $3 /$ & 7.8 & 7.3 & 6.6 & 8.7 & 11.0 & 13.6 & 12.7 & 11.2 & 10.4 \\
\hline \multicolumn{10}{|l|}{ External trade } \\
\hline Exports of goods, volume & 7.0 & 6.1 & 8.4 & 7.8 & 2.6 & -8.9 & 12.5 & 7.5 & 5.2 \\
\hline Imports of goods, volume & 7.4 & 5.7 & 10.0 & 7.5 & 3.4 & -10.1 & 12.2 & 6.1 & 4.8 \\
\hline Terms of trade & -0.4 & 0.5 & -0.3 & -0.1 & -0.1 & -0.8 & -0.6 & -0.2 & -0.5 \\
\hline Merchandise balance (percent of GDP) & 6.7 & 7.4 & 7.0 & 7.3 & 7.1 & 6.4 & 7.2 & 8.4 & 8.7 \\
\hline Current account balance (percent of GDP) & 7.6 & 7.4 & 9.3 & 6.7 & 4.3 & 4.6 & 7.1 & 7.9 & 8.2 \\
\hline \multicolumn{10}{|l|}{ General government accounts (percent of GDP) } \\
\hline Revenue & 44.3 & 44.5 & $46.11 /$ & 45.4 & 46.5 & 45.4 & 45.1 & 45.9 & 46.8 \\
\hline Expenditure & 46.1 & 44.8 & $45.51 /$ & 45.3 & 45.9 & 50.8 & 50.3 & 49.7 & 49.5 \\
\hline Net lending/borrowing & -1.8 & -0.3 & 0.5 & 0.2 & 0.6 & -5.4 & -5.2 & -3.8 & -2.7 \\
\hline Primary balance & 0.7 & 2.1 & 2.7 & 2.4 & 2.7 & -3.3 & -3.3 & -1.7 & -0.5 \\
\hline Structural balance 4/ & -0.9 & 0.4 & 0.1 & -1.2 & -1.0 & -4.4 & -4.1 & -3.2 & -2.2 \\
\hline Structural primary balance 4 / & 1.6 & 2.7 & 2.3 & 1.0 & 1.2 & -2.4 & -2.2 & -1.1 & -- \\
\hline Robust balance 4/ 5/ & -0.5 & 0.5 & -0.4 & -1.6 & -2.2 & -5.2 & -5.0 & -4.2 & -3.1 \\
\hline General government gross debt & 52.4 & 51.8 & 47.4 & 45.3 & 58.2 & 60.8 & 63.7 & 65.6 & 66.5 \\
\hline
\end{tabular}

Sources: Dutch official publications; IMF, IFS; and IMF staff estimates

1/ The introduction of the new health insurance scheme in 2006 caused a significant shift in health care expenditure from private to public consumption, thereby lowering private and raising public consumption growth without changing overall GDP. In a related vein, government revenues rose and private disposable income fall, without affecting the financial position of the public sector or households net terms. This is because public expenditure for health care also rose, while the fall in private disposable income was offset by a similar fall in private health consumption, which is now taken care of in the public domain.

2/ Contribution to GDP growth.

3/ In percent of disposable income.

4/ In percent of potential GDP.

5/ Robust balance is the structural primary balance excluding property income (mainly gas revenue). 
Table 2. Netherlands: Indicators of External and Financial Vulnerability, 2003-10

(In percent of GDP; unless otherwise indicated)

\begin{tabular}{|c|c|c|c|c|c|c|c|c|}
\hline & 2003 & 2004 & 2005 & 2006 & 2007 & 2008 & 2009 & 2010 \\
\hline \multicolumn{9}{|l|}{ External indicators } \\
\hline $\begin{array}{l}\text { Exports goods and services } \\
\text { (annual percent change, in U.S. dollars) }\end{array}$ & 17.8 & 17.0 & 8.6 & 12.4 & 17.5 & 15.8 & -19.9 & 6.6 \\
\hline $\begin{array}{l}\text { Imports goods and services } \\
\text { (annual percent change, in U.S. dollars) }\end{array}$ & 23.6 & 17.9 & 10.0 & 11.4 & 18.0 & 14.0 & -20.0 & 5.5 \\
\hline Terms of trade goods (annual percent change) & 0.8 & -0.4 & 0.5 & -0.3 & -0.1 & -0.1 & -0.8 & 0.6 \\
\hline Current account balance & 5.5 & 7.5 & 7.3 & 9.3 & 8.6 & 4.8 & 5.4 & 6.2 \\
\hline Portfolio investment, net & 4.1 & -5.1 & 12.0 & 3.8 & -11.6 & 14.1 & -0.9 & -1.6 \\
\hline Foreign direct investment, net & -4.3 & -4.0 & -13.2 & -8.4 & 11.1 & -3.2 & 1.2 & -2.1 \\
\hline Official reserves (in billions of Euros) & 17.1 & 15.9 & 17.3 & 18.2 & 18.3 & 20.5 & 21.97 & $\ldots$ \\
\hline $\begin{array}{l}\text { Foreign assets of the banking sector } \\
\text { (in billions of Euros) }\end{array}$ & 446 & 502 & 587 & 723 & 832 & 714 & 685 & $\ldots$ \\
\hline $\begin{array}{l}\text { Foreign liabilities of the banking sector } \\
\text { (in billions of Euros) }\end{array}$ & 396.9 & 447.1 & 506.0 & 605.9 & 737.4 & 593.8 & 597.8 & $\ldots$ \\
\hline Official reserves in months of imports & 0.9 & 0.8 & 0.8 & 0.7 & 0.7 & 0.7 & 0.6 & $\ldots$ \\
\hline Exchange rate (per U.S. dollar, period average) & 0.88 & 0.80 & 0.80 & 0.80 & 0.73 & 0.68 & 0.72 & 0.76 \\
\hline \multicolumn{9}{|l|}{ Financial market indicators } \\
\hline Public sector debt & 52.0 & 52.4 & 51.8 & 47.4 & 45.3 & 58.2 & 60.8 & 64.7 \\
\hline Government bond yield & 4.1 & 4.1 & 3.4 & 3.8 & 4.3 & 4.2 & 3.7 & $\ldots$ \\
\hline Government bond yield (real) & 1.9 & 2.7 & 1.9 & 2.1 & 2.7 & 2.0 & 2.7 & $\ldots$ \\
\hline Stock market index & 329.9 & 338.1 & 413.4 & 488.7 & 523.1 & 258.5 & 317.9 & 343.7 \\
\hline Spread of government bond yield with Germany & 0.05 & 0.06 & 0.02 & 0.02 & 0.07 & 0.24 & 0.46 & ... \\
\hline
\end{tabular}

Sources: Data provided by the authorities; and IMF, IFS. 
Table 3. Netherlands: Financial Soundness Indicators, 2003-10

(In percent; unless otherwise indicated)

\begin{tabular}{|c|c|c|c|c|c|c|c|c|}
\hline Indicator & 2003 & 2004 & 2005 & 2006 & 2007 & 2008 & 2009 & 2010 \\
\hline Regulatory capital-to-risk-weighted assets & 12.3 & 12.3 & 12.6 & 11.9 & 13.2 & 11.9 & 14.9 & 13.9 \\
\hline Regulatory Tier I capital-to-risk-weighted assets & 9.6 & 9.9 & 10.3 & 9.4 & 10.2 & 9.6 & 12.4 & 11.8 \\
\hline Capital to assets & 5.0 & 4.8 & 3.1 & 3.0 & 3.3 & 3.2 & 4.3 & 4.4 \\
\hline Net open position in equities to capital & 59.9 & 79.6 & 80.6 & 91.1 & 83.2 & 31.1 & 34.1 & 24.4 \\
\hline \multicolumn{9}{|l|}{ Contingent and off-balance-sheet accounts to total assets } \\
\hline Nonperforming loans net of provisions to capital $1 /$ & 24.3 & 19.2 & 15.7 & 12.2 & $\ldots$ & 35.0 & 51.8 & 47.1 \\
\hline Nonperforming loans to total gross loans $1 /$ & 2.0 & 1.5 & 1.2 & 0.8 & $\cdots$ & 1.7 & 3.2 & 2.8 \\
\hline Return on assets & 0.5 & 0.4 & 0.4 & 0.4 & 0.6 & -0.4 & 0.0 & 0.3 \\
\hline Return on equity & 14.8 & 16.8 & 15.4 & 15.4 & 18.7 & -12.5 & -0.4 & 7.1 \\
\hline Interest margin to gross income & 60.5 & 58.9 & 54.1 & 51.4 & 52.0 & 182.6 & 69.8 & 71.1 \\
\hline Noninterest expenses to gross income & 75.5 & 70.5 & 70.1 & 74.0 & 78.3 & 285.1 & 101.8 & 66.2 \\
\hline \multicolumn{9}{|l|}{ Sectoral distribution of loans to total loans (percent) } \\
\hline Households & 51.0 & 49.9 & 49.3 & 49.2 & 48.1 & 46.2 & 43.4 & 41.9 \\
\hline Nonfinancial companies & 31.7 & 29.6 & 28.6 & 28.9 & 29.5 & 32.3 & 35.0 & 35.3 \\
\hline Insurance companies and pension funds & 1.0 & 1.7 & 2.0 & 1.9 & 2.0 & 1.7 & 1.3 & 0.7 \\
\hline Other financial institutions & 16.3 & 18.8 & 20.2 & 20.0 & 20.4 & 19.9 & 20.3 & 22.0 \\
\hline Residential mortgage loans to total loans & 25.2 & 25.1 & 28.6 & 26.0 & 24.1 & 24.5 & 25.0 & 23.6 \\
\hline \multicolumn{9}{|l|}{ Geographical distribution of credit (percent of total) } \\
\hline Domestic Economy & & 41.0 & 35.2 & 33.7 & 30.2 & 42.7 & 46.6 & 55.4 \\
\hline Advanced economies & & 54.7 & 59.8 & 60.5 & 61.6 & 49.9 & 46.9 & 39.2 \\
\hline Emerging markets and Developing countries & & 4.3 & 5.0 & 5.9 & 8.2 & 7.4 & 6.5 & 5.4 \\
\hline Africa & & 0.1 & 0.1 & 0.1 & 0.2 & 0.1 & 0.1 & 0.1 \\
\hline of which: Sub- Sahara & & 0.1 & 0.1 & 0.1 & 0.1 & 0.1 & 0.1 & 0.1 \\
\hline Central and Eastern Europe & & 1.1 & 1.2 & 1.2 & 1.9 & 2.7 & 2.5 & 2.5 \\
\hline Commonwealth of independent states and Mongaolia & & 0.3 & 0.4 & 0.5 & 0.7 & 0.9 & 0.6 & 0.5 \\
\hline Developing China, including China & & 0.9 & 0.9 & 1.0 & 1.6 & 1.5 & 1.5 & 1.1 \\
\hline Middle-East & & 0.2 & 0.2 & 0.3 & 0.4 & 0.4 & 0.4 & 0.3 \\
\hline Western Hemisphere & & 1.8 & 2.2 & 2.7 & 3.5 & 1.8 & 1.5 & 1.0 \\
\hline \multicolumn{9}{|l|}{ Assets of financial entities (percent of GDP) } \\
\hline Banks & 309.5 & 341.5 & 330.7 & 341.2 & 380.6 & 374.9 & 387.6 & 382.8 \\
\hline Insurers & 61.6 & 64.3 & 67.3 & 65.0 & 63.2 & 61.8 & 65.5 & 68.7 \\
\hline Pension funds & 102.6 & 109.7 & 123.8 & 128.8 & 133.6 & 119.0 & 130.2 & 135.7 \\
\hline Investment funds & & & & & & 30.9 & 77.8 & 81.6 \\
\hline \multicolumn{9}{|l|}{ Average solvency ratio of insurers (percent) } \\
\hline Life insurers & 259.0 & 264.0 & 301.0 & 326.0 & 262.7 & 209.5 & 245.3 & 245.9 \\
\hline Funeral in kind insurers & 234.0 & 280.0 & 380.0 & 461.0 & 422.7 & 212.5 & 468.6 & 448.1 \\
\hline Non-life insurers & 297.0 & 304.0 & 377.0 & 327.0 & 274.0 & 236.8 & 272.3 & 264.8 \\
\hline Reinsurers & & & & & & 322.0 & 457.9 & 557.2 \\
\hline \multicolumn{9}{|l|}{ No. of pension funds with } \\
\hline Funding ratio $<105 \%$ & & & & & 2.0 & 292.0 & 106.0 & 169.0 \\
\hline Funding ratio $105-130 \%$ & & & & & 151.0 & 92.0 & 233.0 & 158.0 \\
\hline Funding ratio > $130 \%$ & & & & & 283.0 & 25.0 & 35.0 & 20.0 \\
\hline
\end{tabular}

Source: Data provided by the authorities.

1/ Data up to 2006 are for three largest credit institutions. 
Table 4. Netherlands: Summary of State Interventions in Major Financial Institutions

Institution

ABN

AMRO/Fortis

\section{Type of State Intervention}

\section{(i) Acquisition of Fortis'} Dutch operations, including Fortis' share of ABN AMRO for

$€ 16.9$ billion; (ii) a short term bridge loan to Fortis of $€ 34$ billion, (iii) a long term bridge loan to Fortis of $€ 16$ billion, (iv) a state guarantee of $€ 5$ billion bond issue by Fortis, (v) assumption of credit risk in a mortgage portfolio of $€ 19$ billion, which under Basel 1 rules translated to capital release instrument of $€ 1.7$ billion and mandatory convertible note of $€ 0.8$ billion, ( $v$ ) additional capital strengthening actions of $€ 4.4$ billion, of which $€ 1.4$ billion was a debt to equity swap.

Of the roughly $€ 50$ billion in bridge loans,

$€ 39.8$ billion has since been repaid, including all the short term loans.

\section{Conditions Imposed}

\section{Restructuring}

Restrictions on

dividends, bonuses.

Certain decisions by the Managing Board of ABN Amro/Fortis are likely to require approval by the State in her capacity as shareholder.
The restructuring involves consolidating the Dutch banking and insurance operations of former Fortis and ABN AMRO, divestment of most insurance activities, and reconstructing remaining banking operations under a new state-owned bank called ABN AMRO Bank N.V. Legal separation of original $A B N$ AMRO parts to be owned by the Dutch state and RBS has been completed. The authorities intend to divest ABN AMRO Bank N.V. The creation of the envisaged merger of $A B N$ Amro and Fortis required the prior completion of the so-called EC Remedies transaction i.e. a sale of a sizeable Dutch SME portfolio to a third party (Deutsche Bank). The capital consequences of this transaction were taken into account during the assessment of the sufficiency of the additional $€ 4.4$ billion capital strengthening. Fortis Corporate Insurance NV was sold to Lloyds of London.

\section{Background}

ABN AMRO was in the process of being acquired by a consortium including Royal Bank of Scotland, Fortis, and Santander. In October 2008, Fortis experienced financial problems and was rescued, divided and nationalized by the Benelux states. The Dutch authorities separated Fortis' Dutch banking and insurance operations from the rest of Fortis, separated Fortis' share of ABN AMRO, and are well advanced in integrating the two operations, with a view to eventually privatize it. 
Table 4. Netherlands: Summary of State Interventions in Major Financial Institutions

Institution

ING Bank
Type of State Intervention

(i) A capital infusion of $€ 10$ billion through 8.5 percent nonvoting preferred shares; (ii) a facility under which 80 percent of profits or losses on ING's illiquid Alt-A MBS portfolio would be passed to the state for a fee; (iii) ING can issue up to $€ 10$ billion in government-guaranteed bonds ( $€ 2$ billion placed in March 2009).

ING repurchased $€ 5$ billion of Core tier 1 securities in December 2009, in line with its plans for early repayment of the capital injection, and has announced plans to repurchase another $€ 2$ billion by May 2011.

The timing for full redemption is dependent on the resolution of $a$ dispute with the EC on rules governing early redemption.

\section{Conditions Imposed}

\section{Restructuring}

(i) Two Board members with veto rights over fundamental decisions on acquisitions, investments, capital raising and remuneration; (ii) scrap the final 2008 dividend; (iii) grant additional credits of $€ 25$ billion to the private sector; (iv) restrict bonuses; ( $v$ ) pay a step-up coupon if it declares ordinary dividends.
Restructuring is based on the final restructuring plan filed with EC (published 26 October 2009). Besides the Back to Basics programme to streamline the company and reduce risk, costs and leverage, ING will divest all insurance and management activities over time. ING will eliminate double leverage and significantly reduce balance sheet. ING will also divest ING Direct USA. ING will create a new company in the Dutch retail market out of part of its current operations, by combining the Interadvies banking division (including Westland Utrecht and the mortgage activities of Nationale-Nederlanden) and the existing consumer lending portfolio of ING Retail. All restructuring will take place over the years 2010-13.
Background

ING faced significant financial problems stemming from global crisis, valuation losses, an overextended business empire. Unlike ABN AMRO/Fortis transaction, ING remains a principally privately owned and managed bank. 
Table 4. Netherlands: Summary of State Interventions in Major Financial Institutions

\begin{tabular}{|c|c|c|c|c|}
\hline Institution & Type of State Intervention & Conditions Imposed & Restructuring & Background \\
\hline SNS REAAL & $\begin{array}{l}\text { (i) capital injection of } € 750 \\
\text { million by way of interest- } \\
\text { bearing securities with } \\
\text { equity-like features. Of } \\
\text { this injection, } € 185 \text { million } \\
\text { was repaid in December } \\
2009 \text {. }\end{array}$ & $\begin{array}{l}\text { (i) Restrictions on } \\
\text { executive } \\
\text { compensation and } \\
\text { dividends; (ii) } \\
\text { incentives for early } \\
\text { repayment similar to } \\
\text { ING; (iii) a parallel } \\
\text { capital infusion of } \\
€ 500 \text { million by } \\
\text { Stichting Beheer } \\
\text { SNS REAAL. }\end{array}$ & No major restructuring intended. & \\
\hline
\end{tabular}


Table 5a. Netherlands: General Government Statement of Operations, 2004-12 (In percent of GDP)

\begin{tabular}{|c|c|c|c|c|c|c|c|c|c|}
\hline & 2004 & 2005 & 2006 & 2007 & 2008 & 2009 & $\begin{array}{l}2010 \\
\text { Proj. }\end{array}$ & $\begin{array}{l}2011 \\
\text { Proj. }\end{array}$ & $\begin{array}{l}2012 \\
\text { Proj. }\end{array}$ \\
\hline Revenue 1/ & 44.3 & 44.5 & 46.1 & 45.4 & 46.5 & 45.4 & 45.1 & 45.9 & 46.8 \\
\hline Taxes & 23.1 & 24.2 & 24.5 & 24.7 & 24.0 & 23.8 & 24.0 & 23.6 & 23.7 \\
\hline Taxes on production and imports & 12.4 & 12.4 & 12.6 & 12.5 & 12.1 & 11.7 & 11.9 & 11.7 & 11.7 \\
\hline Current taxes on income, wealth, etc. & 10.4 & 11.4 & 11.5 & 11.9 & 11.6 & 11.8 & 11.8 & 11.6 & 11.7 \\
\hline Capital taxes & 0.3 & 0.3 & 0.3 & 0.3 & 0.3 & 0.3 & 0.3 & 0.3 & 0.3 \\
\hline Social contributions & 14.9 & 13.9 & 14.8 & 14.2 & 15.2 & 14.5 & 14.7 & 15.6 & 16.1 \\
\hline Grants & 0.5 & 0.5 & 0.4 & 0.4 & 0.4 & 0.4 & 0.4 & 0.4 & 0.4 \\
\hline Other revenue & 5.8 & 6.0 & 6.3 & 6.1 & 6.9 & 6.6 & 5.9 & 6.2 & 6.6 \\
\hline Expenditure 1/ & 46.1 & 44.8 & 45.5 & 45.3 & 45.9 & 50.8 & 50.3 & 49.7 & 49.5 \\
\hline Expense & 45.1 & 43.8 & 44.7 & 44.2 & 44.5 & 48.3 & 48.2 & 47.7 & 47.8 \\
\hline Compensation of employees & 10.0 & 9.6 & 9.3 & 9.2 & 9.2 & 9.9 & 10.0 & 9.7 & 9.6 \\
\hline Use of goods and services & 7.2 & 7.1 & 7.2 & 7.2 & 7.4 & 8.2 & 8.1 & 8.0 & 7.8 \\
\hline Consumption of fixed capital & 2.5 & 2.5 & 2.5 & 2.5 & 2.5 & 2.7 & 2.7 & 2.7 & 2.7 \\
\hline Interest & 2.5 & 2.4 & 2.2 & 2.2 & 2.1 & 2.1 & 1.9 & 2.1 & 2.2 \\
\hline Subsidies & 1.4 & 1.2 & 1.1 & 1.3 & 1.2 & 1.5 & 1.6 & 1.4 & 1.4 \\
\hline Grants & 1.9 & 1.9 & 1.9 & 1.7 & 1.8 & 1.4 & 1.3 & 1.4 & 1.6 \\
\hline Social benefits & 19.6 & 19.0 & 20.3 & 20.1 & 20.2 & 22.3 & 22.4 & 22.3 & 22.4 \\
\hline Other expense & 0.1 & 0.1 & 0.1 & 0.1 & 0.1 & 0.1 & 0.1 & 0.1 & 0.1 \\
\hline Net acquisition of nonfinancial assets & 1.0 & 1.0 & 0.8 & 1.1 & 1.4 & 2.5 & 2.1 & 2.0 & 1.6 \\
\hline Gross/Net operating balance & -0.8 & 0.7 & 1.4 & 1.2 & 2.0 & -2.9 & -3.1 & -1.8 & -1.1 \\
\hline Net lending/borrowing & -1.8 & -0.3 & 0.5 & 0.2 & 0.6 & -5.4 & -5.2 & -3.8 & -2.7 \\
\hline Net acquisition of financial assets & -0.2 & 1.1 & -0.5 & 1.0 & 14.8 & -4.6 & $\ldots$ & $\ldots$ & $\ldots$ \\
\hline Currency and deposits & 0.1 & 1.2 & -0.7 & 1.2 & 0.0 & 0.4 & $\ldots$ & $\ldots$ & $\ldots$ \\
\hline Securities other than shares & 0.0 & 0.0 & 0.0 & 0.1 & 0.0 & 3.7 & $\ldots$ & $\ldots$ & $\ldots$ \\
\hline Loans & 0.0 & 0.5 & 0.0 & 0.5 & 7.5 & -4.9 & $\ldots$ & $\ldots$ & $\ldots$ \\
\hline Shares and other equity & -0.2 & -0.2 & -0.9 & -0.4 & 6.2 & -4.4 & $\cdots$ & $\cdots$ & $\ldots$ \\
\hline Insurance technical reserves & 0.0 & 0.0 & 0.0 & 0.0 & 0.0 & 0.0 & $\ldots$ & $\ldots$ & $\ldots$ \\
\hline Financial derivatives & 0.0 & 0.0 & 0.0 & 0.0 & 0.0 & 0.0 & $\ldots$ & $\ldots$ & $\ldots$ \\
\hline Other accounts receivable & -0.1 & -0.4 & 1.2 & -0.2 & 1.0 & 0.6 & $\cdots$ & $\cdots$ & $\ldots$ \\
\hline Net incurrence of liabilities & 1.6 & 1.4 & -1.0 & 0.9 & 14.2 & 0.8 & $\ldots$ & $\ldots$ & $\ldots$ \\
\hline Special Drawing Rights (SDRs) & 0.0 & 0.0 & 0.0 & 0.0 & 0.0 & 0.0 & $\ldots$ & $\ldots$ & $\ldots$ \\
\hline Currency and deposits & 0.0 & 0.0 & 0.0 & 0.0 & 0.0 & 0.0 & $\ldots$ & $\ldots$ & $\ldots$ \\
\hline Securities other than shares & 2.4 & 1.0 & -1.8 & -0.5 & 12.5 & -2.4 & $\ldots$ & $\ldots$ & $\ldots$ \\
\hline Loans & -0.4 & 0.6 & -0.2 & 1.1 & 2.2 & 3.1 & $\ldots$ & $\ldots$ & $\ldots$ \\
\hline Shares and other equity & 0.0 & 0.0 & 0.0 & 0.0 & 0.0 & 0.0 & $\ldots$ & $\ldots$ & $\ldots$ \\
\hline Insurance technical reserves & 0.0 & 0.0 & 0.0 & 0.0 & 0.0 & 0.0 & $\ldots$ & $\ldots$ & $\ldots$ \\
\hline Financial derivatives & 0.0 & 0.0 & 0.0 & 0.0 & 0.0 & 0.0 & $\ldots$ & $\ldots$ & $\ldots$ \\
\hline Other accounts payable & -0.4 & -0.2 & 1.0 & 0.3 & -0.5 & 0.1 & $\cdots$ & $\ldots$ & $\ldots$ \\
\hline \multicolumn{10}{|l|}{ Memorandum items: } \\
\hline Primary balance & 0.7 & 2.1 & 2.7 & 2.4 & 2.7 & -3.3 & -3.3 & -1.7 & -0.5 \\
\hline Structural balance (in percent of potential GDP) & -0.9 & 0.4 & 0.1 & -1.2 & -1.0 & -4.4 & -4.1 & -3.2 & -2.2 \\
\hline Structural primary balance (in percent of potential GDP) & 1.6 & 2.7 & 2.3 & 1.0 & 1.2 & -2.4 & -2.2 & -1.1 & 0.0 \\
\hline Robust balance (in percent of potential GDP) & -0.5 & 0.5 & -0.4 & -1.6 & -2.2 & -5.2 & -5.0 & -4.2 & -3.1 \\
\hline Gross Debt & 52.4 & 51.8 & 47.4 & 45.3 & 58.2 & 60.8 & 63.7 & 65.6 & 66.5 \\
\hline Output gap & -0.8 & -0.3 & 1.2 & 2.5 & 2.2 & -2.5 & -1.6 & -0.9 & -0.6 \\
\hline
\end{tabular}

Sources: The Netherlands' Bureau for Economic Policy Analysis (CPB), Ministry of Finance, and Fund staff calculations and estimates.

1/ The introduction of the new healthcare system in 2006 did not affect the overall balance, but permanently increased both revenue and expenditure by 1.6 percentage points of GDP. 
Table 5b. Netherlands: General Government Integrated Balance Sheet, 2004-09

(In percent of GDP)

\begin{tabular}{|c|c|c|c|c|c|c|}
\hline & 2004 & 2005 & 2006 & 2007 & 2008 & 2009 \\
\hline Net Worth & $\cdots$ & $\ldots$ & $\ldots$ & $\ldots$ & & $\ldots$ \\
\hline Nonfinancial assets & $\ldots$ & $\ldots$ & $\ldots$ & $\ldots$ & $\ldots$ & $\ldots$ \\
\hline Net Financial Worth & -37.6 & -35.0 & -31.6 & -27.9 & -26.8 & -29.9 \\
\hline Financial assets & 24.3 & 25.7 & 22.9 & 23.7 & 37.7 & 37.8 \\
\hline Currency and deposits & 2.3 & 3.4 & 2.3 & 3.3 & 3.2 & 3.7 \\
\hline Securities other than shares & 0.1 & 0.1 & 0.0 & 0.1 & 0.1 & 3.4 \\
\hline Loans & 5.3 & 5.6 & 5.2 & 5.4 & 12.7 & 8.4 \\
\hline Shares and other equity & 8.7 & 9.5 & 8.0 & 8.5 & 15.0 & 15.2 \\
\hline Insurance technical reserves & 0.0 & 0.0 & 0.0 & 0.0 & 0.0 & 0.0 \\
\hline Financial derivatives & 0.1 & 0.2 & 0.1 & -0.2 & 0.3 & 0.0 \\
\hline Other accounts receivable & 7.8 & 7.1 & 7.3 & 6.5 & 6.3 & 7.2 \\
\hline Liabilities & 61.9 & 60.7 & 54.5 & 51.5 & 64.5 & 67.6 \\
\hline Special Drawing Rights (SDRs) & 0.0 & 0.0 & 0.0 & 0.0 & 0.0 & 0.0 \\
\hline Currency and deposits & 0.1 & 0.1 & 0.1 & 0.1 & 0.1 & 0.1 \\
\hline Securities other than shares & 46.3 & 45.4 & 39.8 & 36.4 & 49.2 & 48.8 \\
\hline Loans & 8.6 & 8.9 & 8.2 & 8.8 & 10.7 & 13.9 \\
\hline Shares and other equity & 0.0 & 0.0 & 0.0 & 0.0 & 0.0 & 0.0 \\
\hline Insurance technical reserves & 0.0 & 0.0 & 0.0 & 0.0 & 0.0 & 0.0 \\
\hline Financial derivatives & 0.0 & 0.0 & 0.0 & 0.0 & 0.0 & 0.0 \\
\hline Other accounts payable & 6.8 & 6.2 & 6.3 & 6.2 & 4.5 & 4.8 \\
\hline
\end{tabular}

Sources: The Netherlands' Ministry of Finance, and Fund staff calculations. 
Table 6. Netherlands: Main FSAP Update Recommendations

Recommendations

Macroprudential Management

Assign priority to developing macro-prudential instruments.

Announce maximum loan-to-value (LTV) ratios for new lending, and consider linking higher LTVs to higher capital ratios.

Provide supervisors with powers to vary the level of designated macroprudential instruments in response to developments.

Announce plans to reduce mortgage interest deductibility

\section{Twin Peaks}

Afford legal protection to DNB and the AFM as institutions, for their official actions, except in cases of gross negligence or willful misconduct, in line with practice in many neighboring countries.

Provide the DNB and AFM greater discretion to put in place enforceable rules. The lack of sufficient rule making authority leads to ad hoc approaches that risk becoming arbitrary and subject to legal challenge.

Continue integration of DNB staff across banking, insurance, and pensions functions, so as to draw the synergies of having a single regulator.

\section{Microprudential Bank and Insurance Supervision}

Establish routine reporting requirements to strengthen monitoring and risk modeling. Intensify supervision of large international financial institutions, with greater emphasis on group supervision and soundness of business models. Greater international cooperation, beyond participation in colleges of supervisors, is warranted.

Adopt more proactive and decisive approach, including timely off-site inspection and corrective actions that rely less on moral suasion.

\section{Securities market}

Strengthen the AFM's ability to enforce issuers' compliance with financial reporting standards.

Strengthen the regulatory and supervisory framework for management companies of collective investment schemes (CIS).

\section{Pensions}

Develop a communication plan on recent and prospective changes in payouts to stakeholders.

Require incorporation of professional Board members for pension funds beyond a minimum size, and provide legal authority that allows direct supervision of core pension activities independently of the entity performing them.

\section{Crisis management and bank resolution}

Reform the Deposit Guarantee Scheme so that it is: (i) ex ante funded, (ii) authorized to fund bank resolution operations, and (iii) enjoys depositor preference. Strengthen the institutional framework for crisis management by: (i) shifting decision-making power from the Judiciary to DNB in the context of bank resolution, and (ii) specifying more clearly the respective roles of the MoF and DNB in bank resolution.

Improve the framework for official financial support by establishing a standing budgetary authorization for the Government to fund solvency support in a manner that avoids risk of moral hazard.

Improve the framework for bank resolution by establishing a single regime for resolving banks under official control; such regime should set appropriate objectives (including financial stability), as well as tasks and powers for the official administrators.

\begin{tabular}{|c|c|}
\hline Timeframe & Priority \\
\hline Short Term & High \\
\hline Short Term & High \\
\hline Short Term & Medium \\
\hline $\begin{array}{l}\text { Immediate } \\
\text { announcement. } \\
\text { Implementation over } \\
\text { the medium term }\end{array}$ & High \\
\hline Short Term & High \\
\hline Short Term & High \\
\hline Medium Term & Medium \\
\hline Short Term & High \\
\hline Short Term & High \\
\hline Short Term & High \\
\hline Medium Term & High \\
\hline Medium Term & Medium \\
\hline Short Term & High \\
\hline Medium Term & Medium \\
\hline Short Term & High \\
\hline Short Term & Medium \\
\hline Short Term & Medium \\
\hline Short Term & High \\
\hline
\end{tabular}


Further pension reform:

- Raising retirement age.

- $\quad$ Lowering accrual rate for pension benefits.

- $\quad$ Tightening early retirement.

Savings in health and long-term care:

- Increase in user fees.

- Tightening entitlements to long term care.

- $\quad$ Productivity increases

- Benchmarking.
The state pension has not been changed since it was set up in 1957, even as life expectancy has increased by more than 6 years and a strong second-pillar pension system has been built up. Also, it is relatively generous by international standards, at about 31 percent of average earnings compared to an average 22 percent for neighboring countries.

Health-care spending and long-term care expenditure are projected to rise by one percent and 4 percent of GDP by 2060 , respectively with population aging, due in part to expensive advances in medical technology and real income growth, given high income elasticity of health-services demand. Thus, an increase in user fees could moderate demand growth, although care should be taken to prevent overburdening the chronically ill. Tightening entitlements in long-term care could spawn savings in an area where aging pressures in Netherlands are the highest in the EU. Productivity increases in health- and long-term care of $1 / 2$ percent a year (which has been achieved in some OECD countries) would lower significantly projected rises in spending. Domestic and international benchmarking to identify best practices would also be beneficial.
The authorities do not dispute the need for such measures. They have already moved in this area by abolishing tax incentives for early retirement. However, plans to raise the statutory retirement age by two years to 67 by 2025 have been scaled back and an increase to 66 years is now envisaged, with ongoing discussion on linking the retirement age to longevity thereafter.

Major health care reforms in 2006 have increased competition and dampened the rise of costs. Further modest savings are envisaged as part of the new government's fiscal adjustment measures. They are also considering increases in user fees and tighter entitlements in long term care, but emphasize the need to keep extensive availability of social services given societal preferences. 
Substantial reduction in mortgage interest tax deductibility.

- $\quad$ Prompt announcement with an appropriately long phase in period to avoid disruptions in the housing market.
Very liberal deductibility has helped put upward pressure on house prices, mortgage size, and mortgage loan to value ratios, thus raising household indebtedness and vulnerabilities in the housing market. Moreover, it constitutes a large tax expenditure (about 7 percent of fiscal revenues).
Political pressures imply that this cannot be implemented at least in the short run. 
Table 8. Netherlands: Policy Responses to the Recommendation to Improve Labor Supply

\begin{tabular}{|c|c|}
\hline Timeline & Policy Response \\
\hline & General \\
\hline \multirow[t]{2}{*}{2009} & - Reduce Unemployment Fund (AWF) premium for employees to 0 percent \\
\hline & Women \\
\hline 2008 & - Increase supplementary combination tax credit (ACK) \\
\hline 2008 & - Establish Part-time Plus Task Force \\
\hline 2009 & $\begin{array}{l}\text { - Convert supplementary combination tax credit into income-based supplementary } \\
\text { combination tax credit (IACK) }\end{array}$ \\
\hline \multirow[t]{2}{*}{2009} & - Phase out transferability of general tax credit over 15 -year period \\
\hline & Older workers \\
\hline 2009 & $\begin{array}{l}\text { - Convert premium exemption into a targeted temporary premium discount for older } \\
\text { unemployed workers }\end{array}$ \\
\hline \multirow[t]{2}{*}{2009} & $\begin{array}{l}\text { - Introduce bonus for continuing to work after reaching the age of } 62 \\
\text { - Increase statutory retirement age from } 65 \text { to } 67\end{array}$ \\
\hline & Vulnerable groups \\
\hline 2008 & $\begin{array}{l}\text { - Implement employment scheme to facilitate the creation of jobs for those receiving } \\
\text { benefits under the Work and Social Assistance Act ('participation jobs') }\end{array}$ \\
\hline 2008 & $\begin{array}{l}\text { - Conclude agreements with the } 39 \text { regions of the Regional Registration and } \\
\text { Coordination Centers (RMCs) to address school drop-out levels }\end{array}$ \\
\hline 2009 & $\begin{array}{l}\text { - Introduce a stricter definition of 'appropriate work' in the Unemployment Insurance Act } \\
\text { (WW) }\end{array}$ \\
\hline 2009 & - Introduce earned income tax credit \\
\hline 2009 & $\begin{array}{l}\text { - Introduce temporary wage cost subsidy for long-term unemployed under the age of } 50 \\
\text { (STAP) }\end{array}$ \\
\hline 2009 & - Introduce integrated services at the regional Locations for Work and Income \\
\hline 2009 & - Introduce budget for municipalities to promote labor market participation \\
\hline 2009 & - Introduce Investment in the Young Act (WIJ) \\
\hline 2010 & $\begin{array}{l}\text { - Adjust income benefits for young disabled persons under the Invalidity Insurance } \\
\text { (Young Disabled Persons) Act (Wajong) }\end{array}$ \\
\hline 2010 & $\begin{array}{l}\text { - Extension of the premium reduction on education to encourage investment in } \\
\text { education and promote reintegration in the formal labor market (WVA) }\end{array}$ \\
\hline
\end{tabular}

Source: Annual Progress Report 2009 and national authorities, The Netherlands, in the context of the Lisbon Strategy and the Europe 2020 strategy. 
Figure 1. Netherlands: International Comparisons of Financial Markets (2009, in percent of GDP)
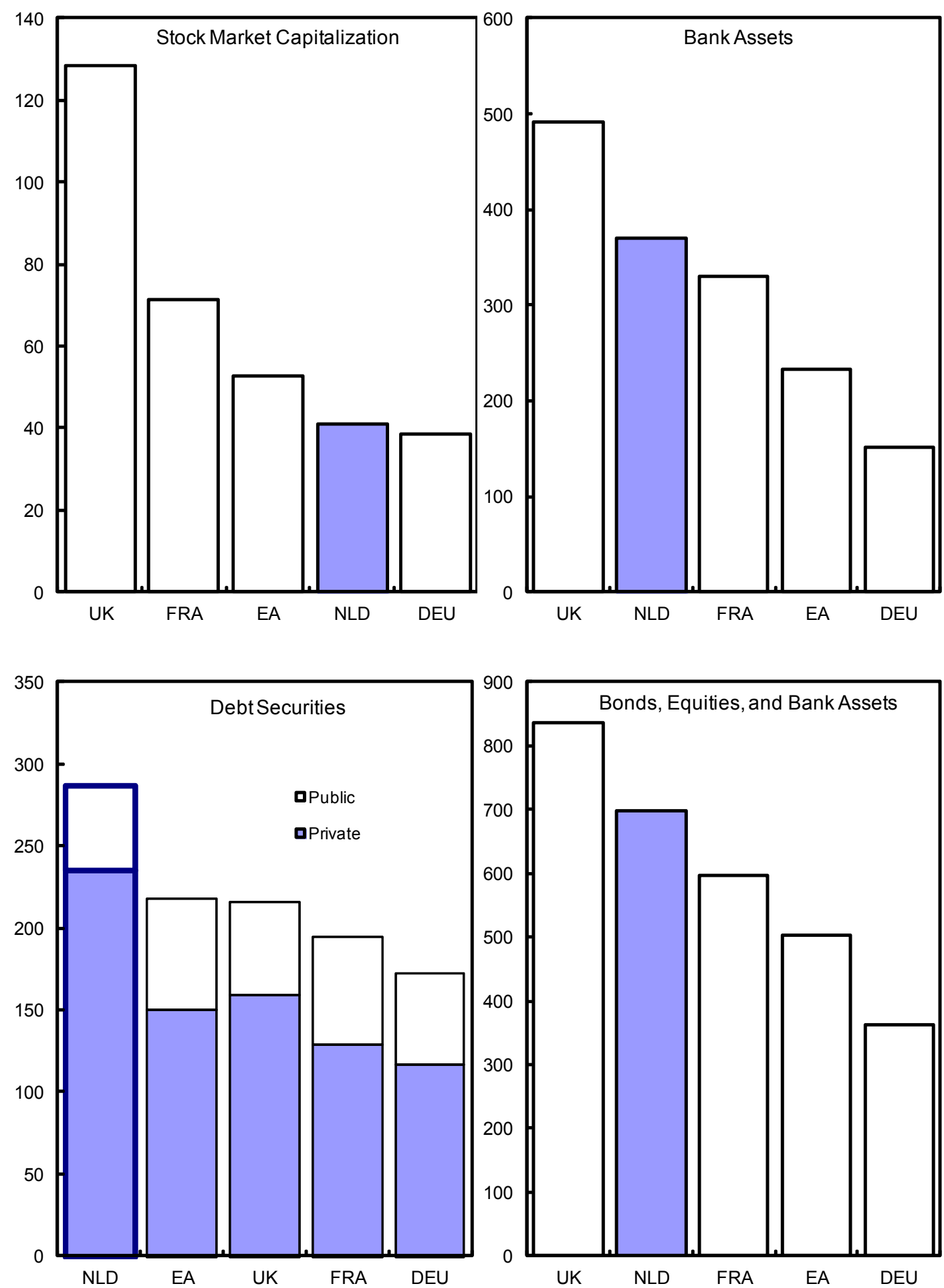

Source: IMF, Global Financial Stability Report. 
Figure 2. Netherlands: Real Sector Developments
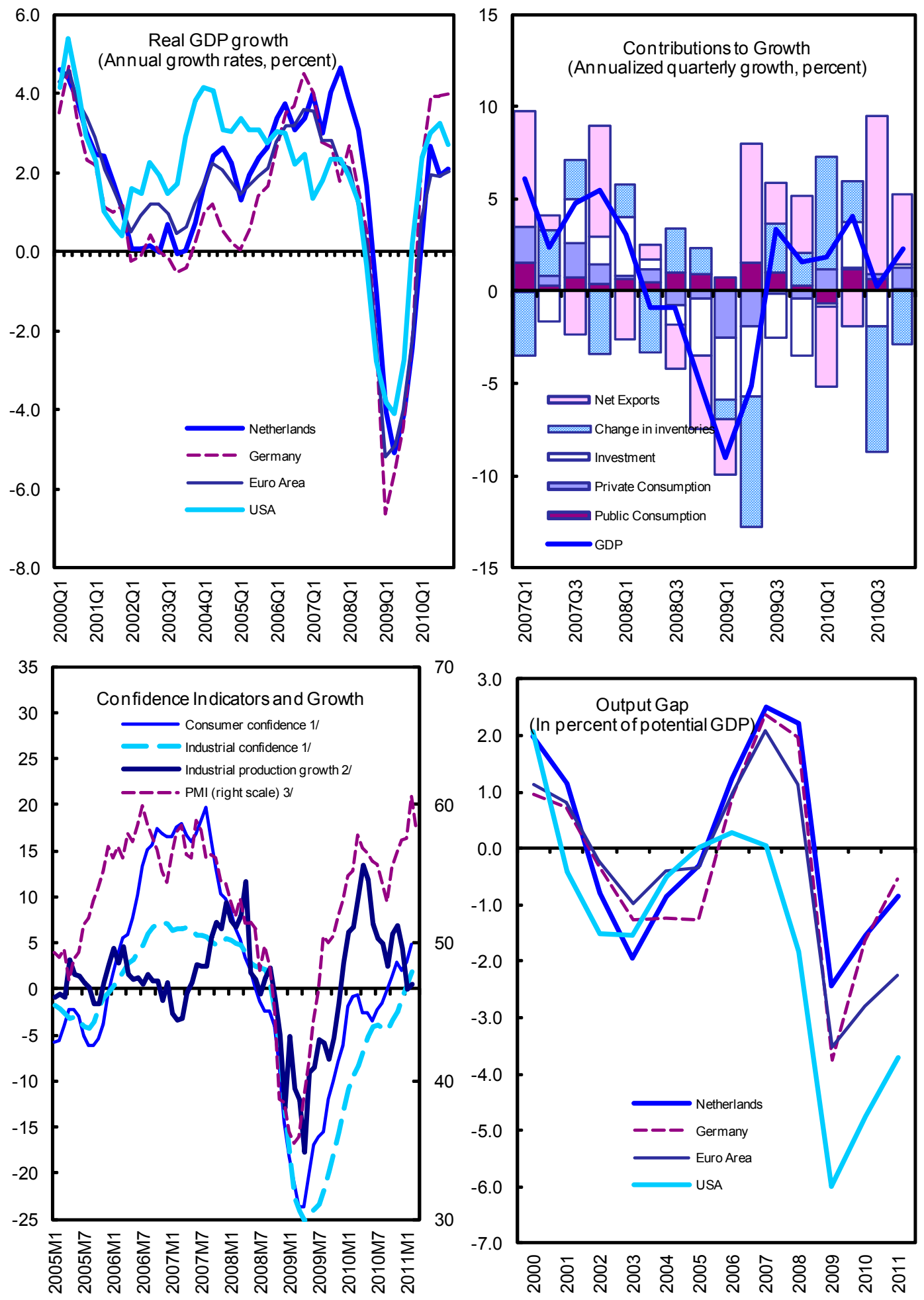

Sources: Haver Analytics; IMF, WEO; and IMF staff estimates.

1/Percent balance.

2/Percent.

3/ PMI: Manufacturing (SA, 50+=Expansion). 
Figure 3. Netherlands: Comparative Economic Performance

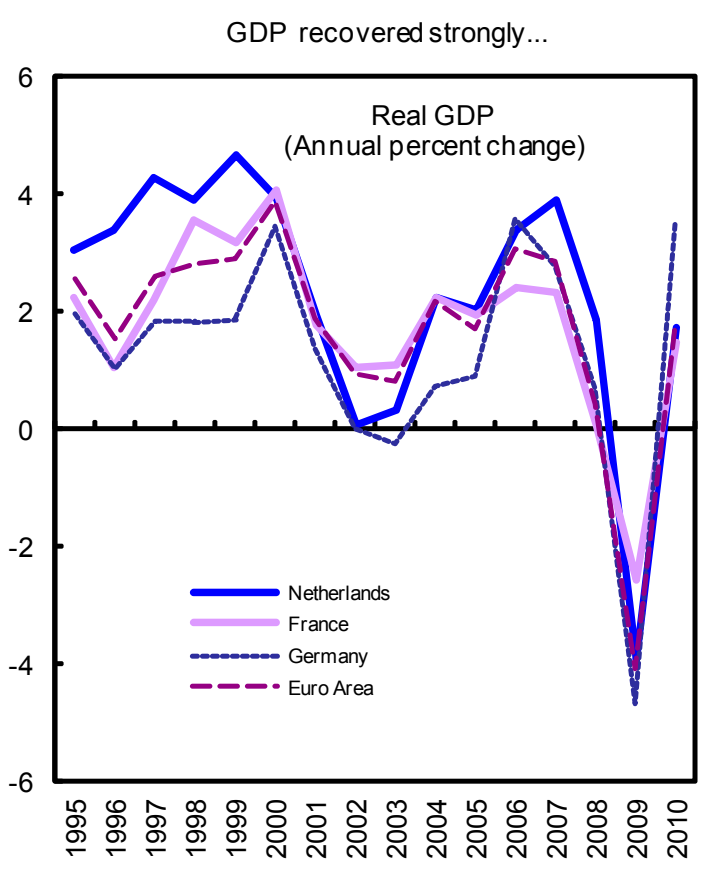

Business investment remains subdued...

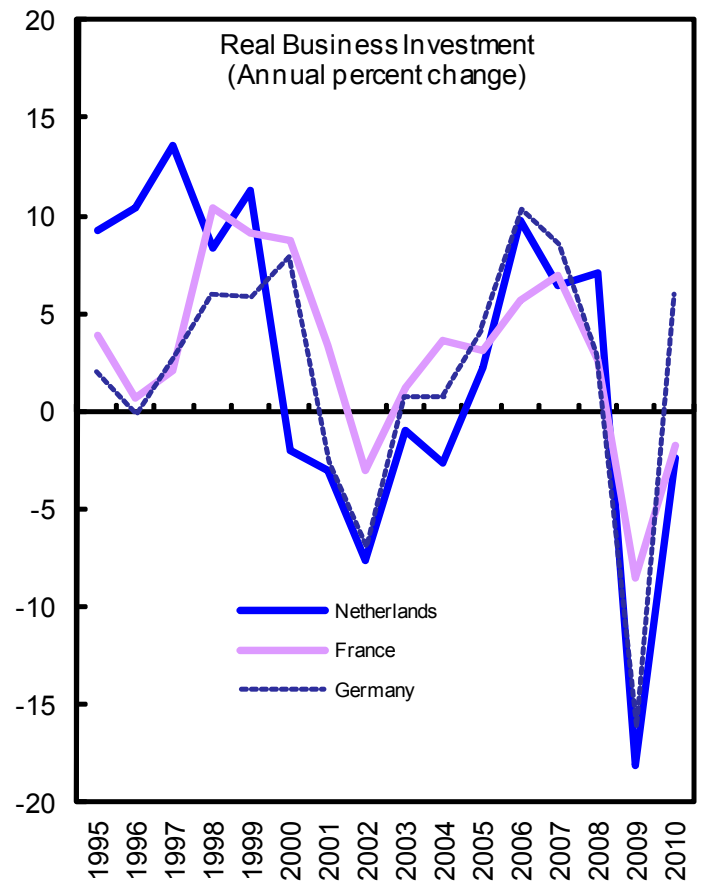

.. led by exports.

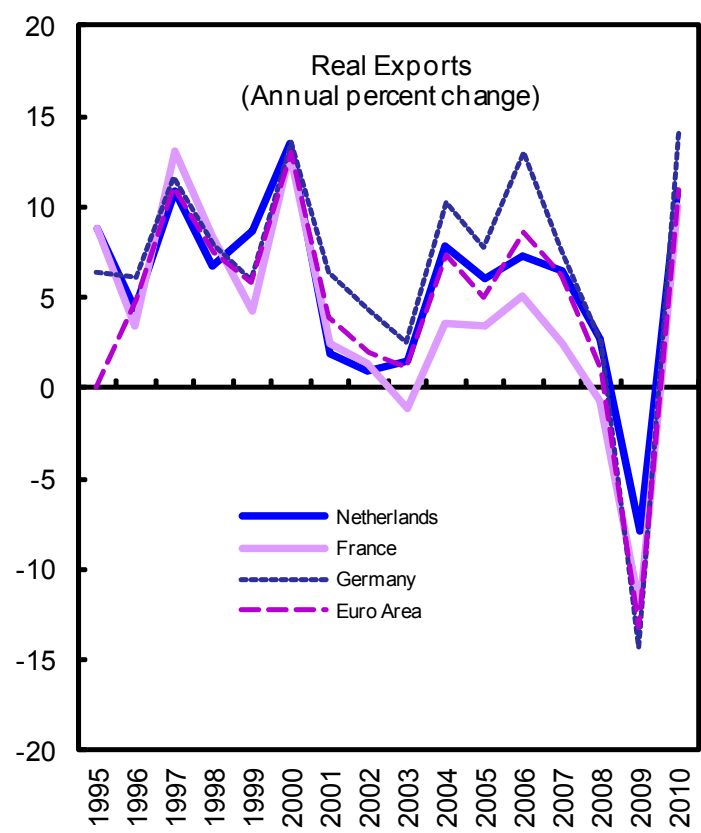

...as does private consumption.

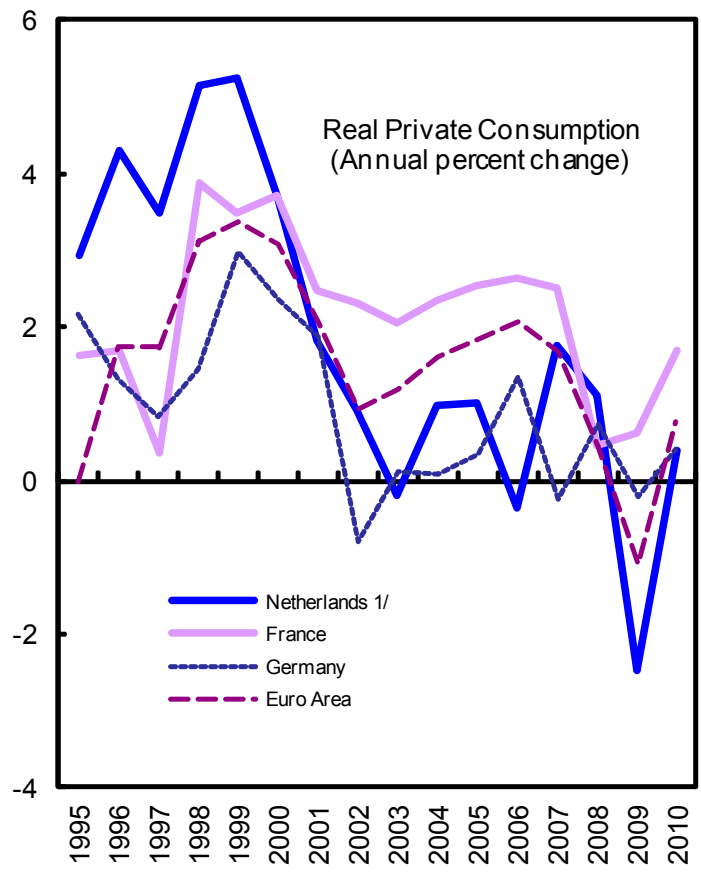

Sources: Global Insight; Netherlands authorities; OECD; and IMF, WEO.

$1 /$ The consumption growth in 2006 is adjusted for the heal th care reform. The reform of the health care systemat the beginning of 2006 resulted in a shift of health care expenditures of about euro 8.0 billion (1.5 percent of GDP) from private to public consumption, distorting private consumption downward by about 3 percentage points in 2006. 
Figure 4. Netherlands: External Competitiveness

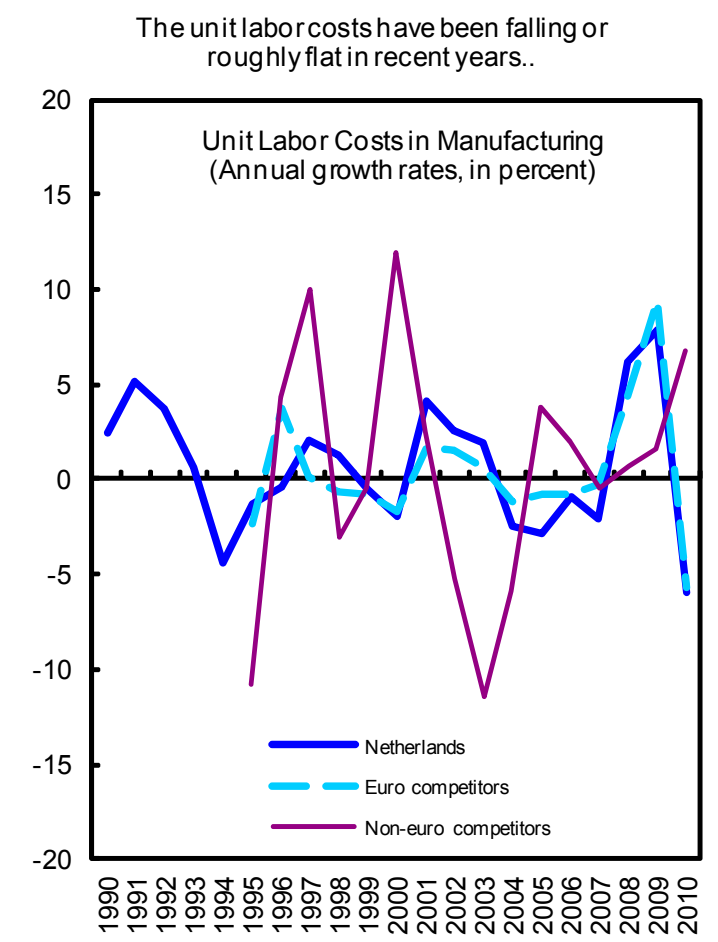

Nominal exchange rate appreciation has reversed the recent real depreciation.
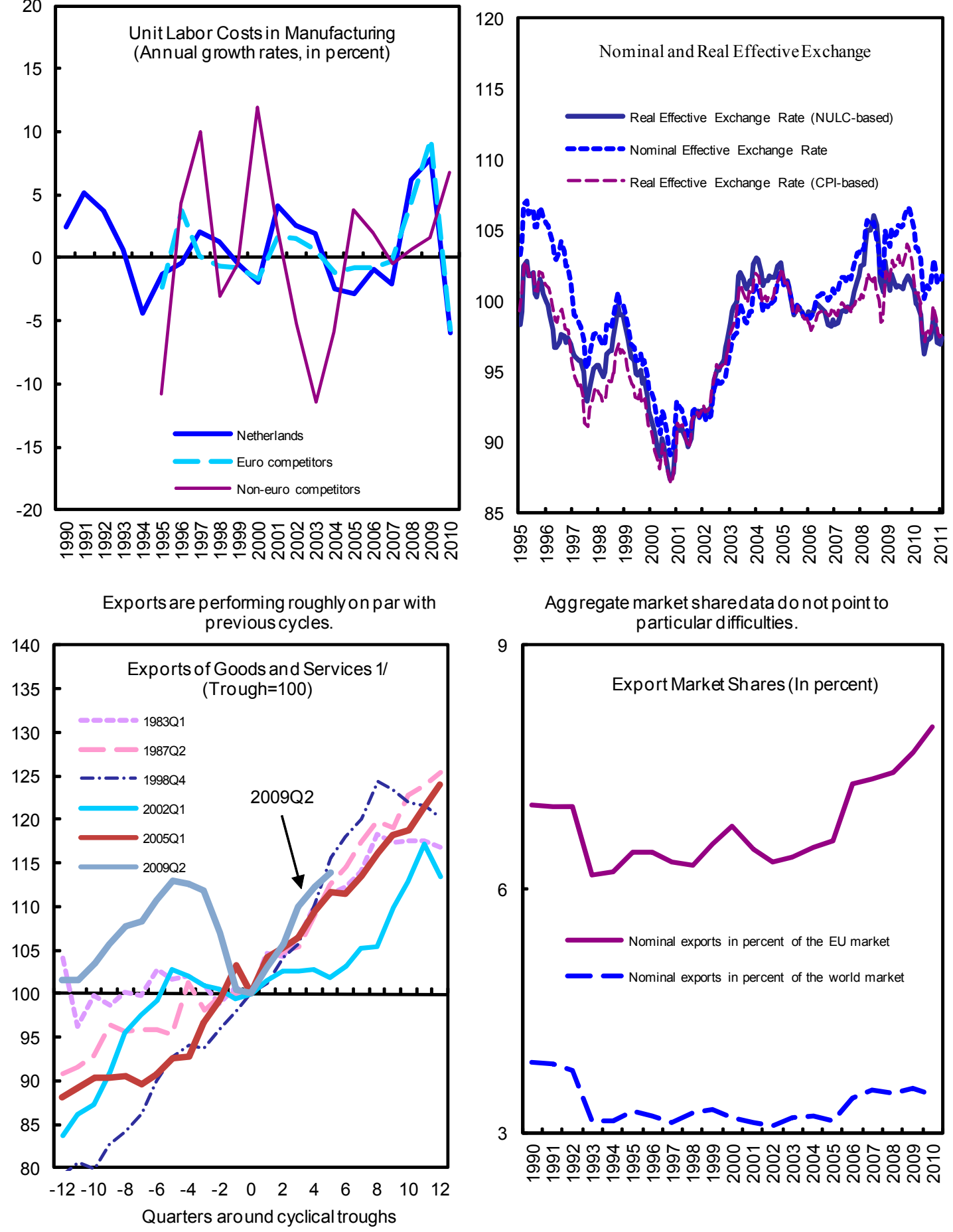

Aggregate market share data do not point to particular difficulties.

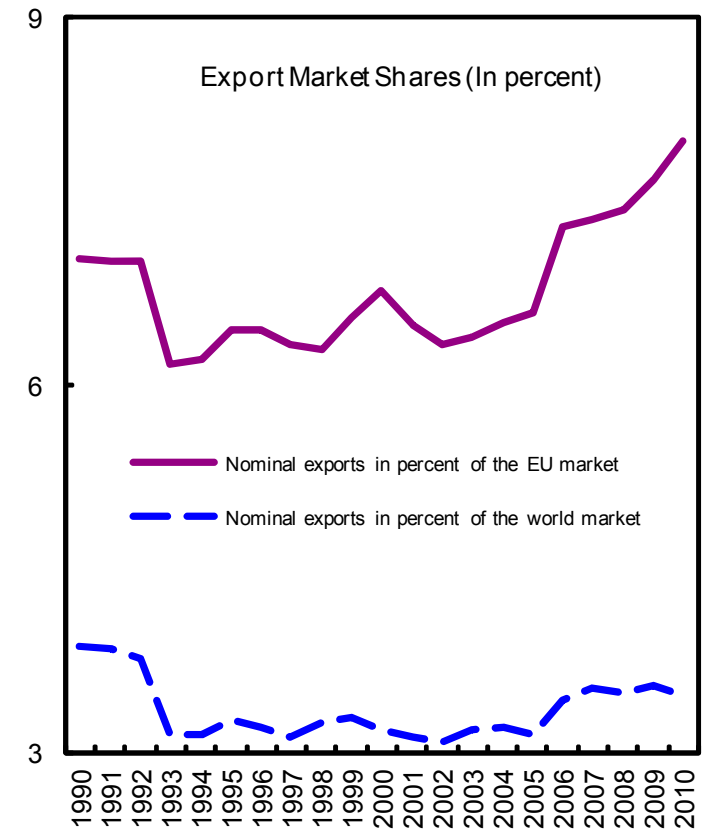

Sources: CPB; OECD, Economic outlook; IMF, IFS, DOT, and WEO.

1/ Trough s were identified using the meth odology of Harding and Pagan (2002), "Dissecting the Cycle: A Methodological Investigation," Journal of Monetary Economics. 
Figure 4. Netherlands: External Competitiveness (concluded)

Export market share has ten ded to decline in many countries, partly reflecting the expansion of exports from many emerging market countries such as Ch ina \& India. On a comparative basis, the Netherlands is performing well among European countries.

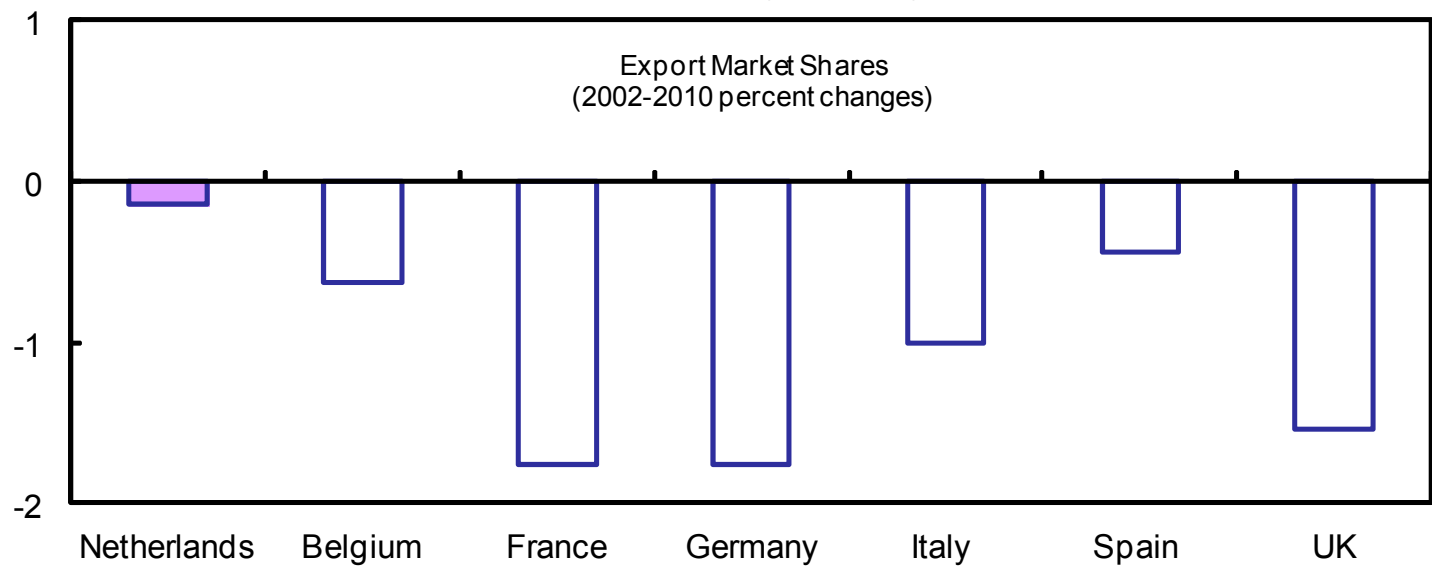

Reexports have registered particularly strong growth.
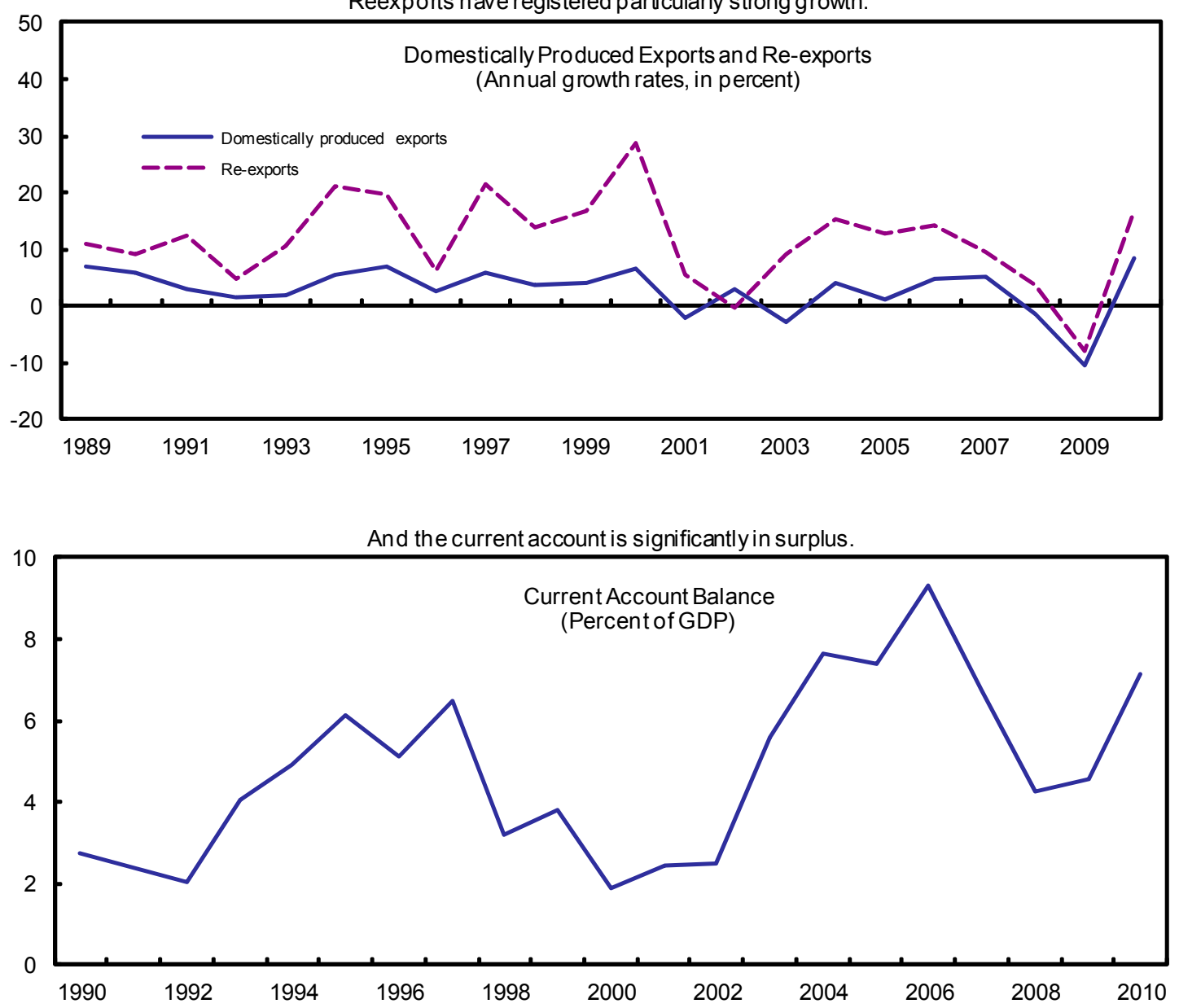

Sources CPB; IMF, IFS, DOT, and WEO. 
Figure 5. Netherlands: Trade Openness and Spillovers
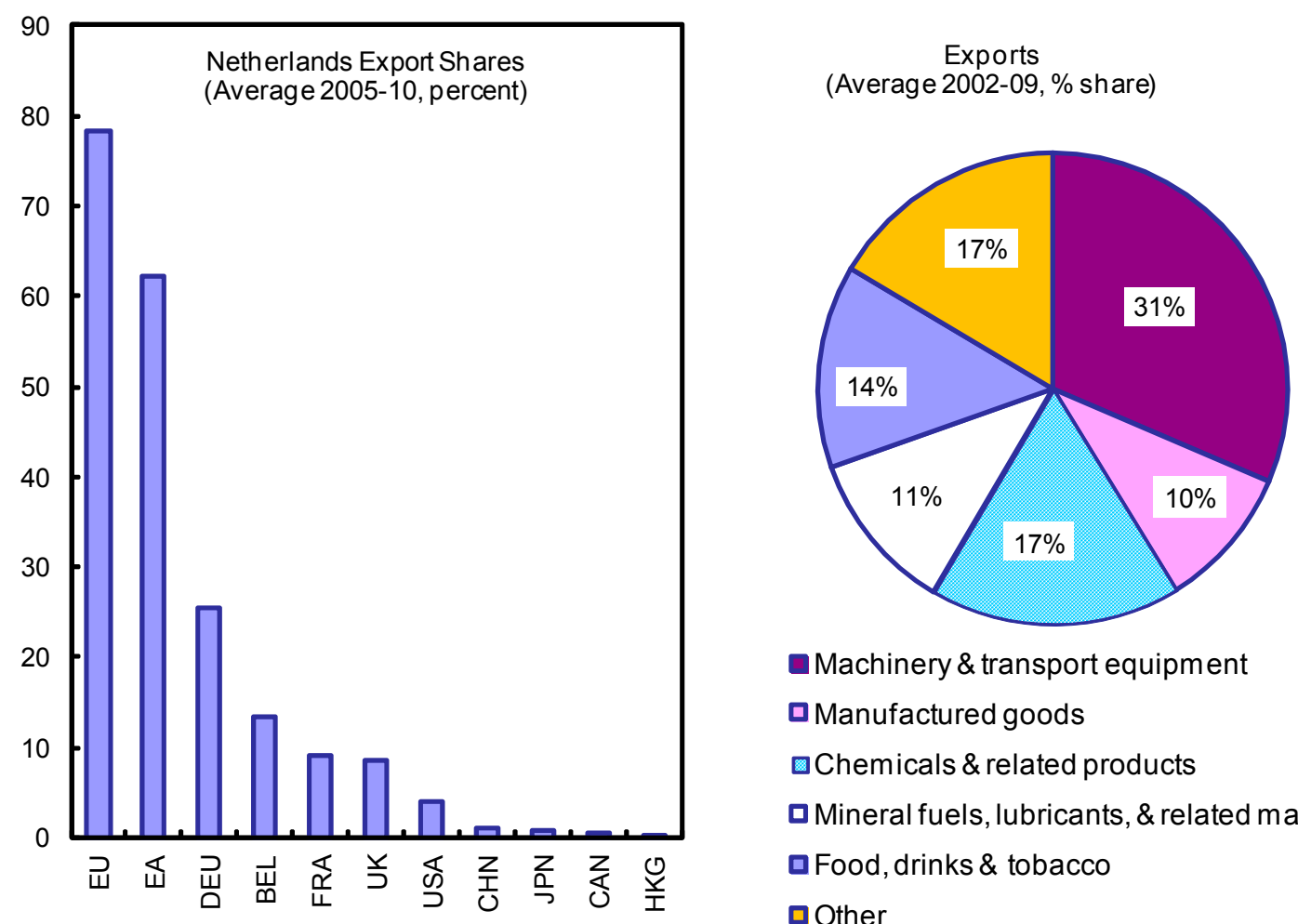

Machinery \& transport equipment

a Manufactured goods

$\square$ Chemicals \& related products

- Mineral fuels, lubricants, \& related materials

rFood, drinks \& tobacco

口 Other
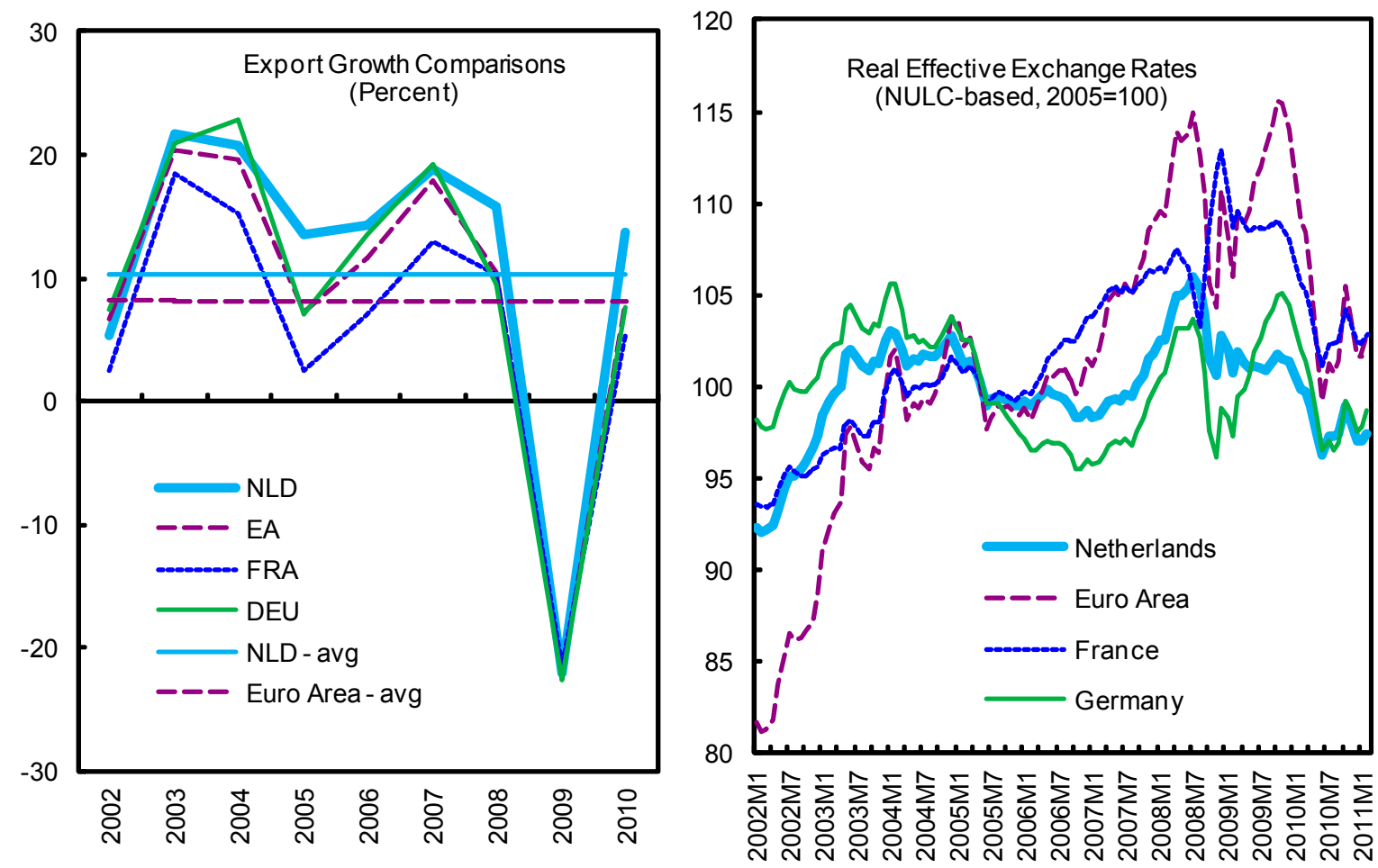

Sources: EIU and IMF; DOT and IFS. 
Figure 6. Netherlands: Comparative Financial In dicators
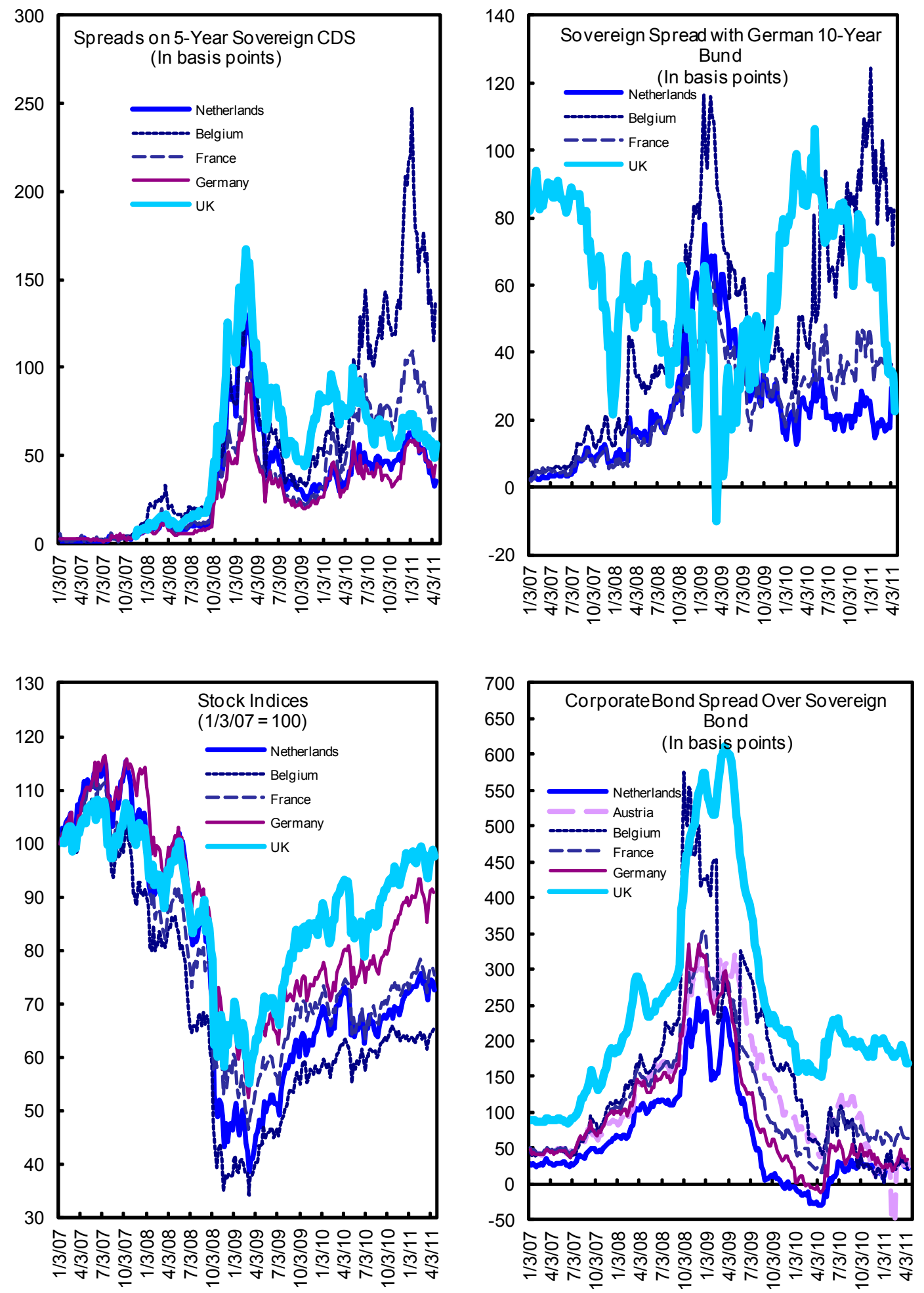

Source: Thomson Financial/DataStream. 
Figure 7. Netherlands: Financial In dicators
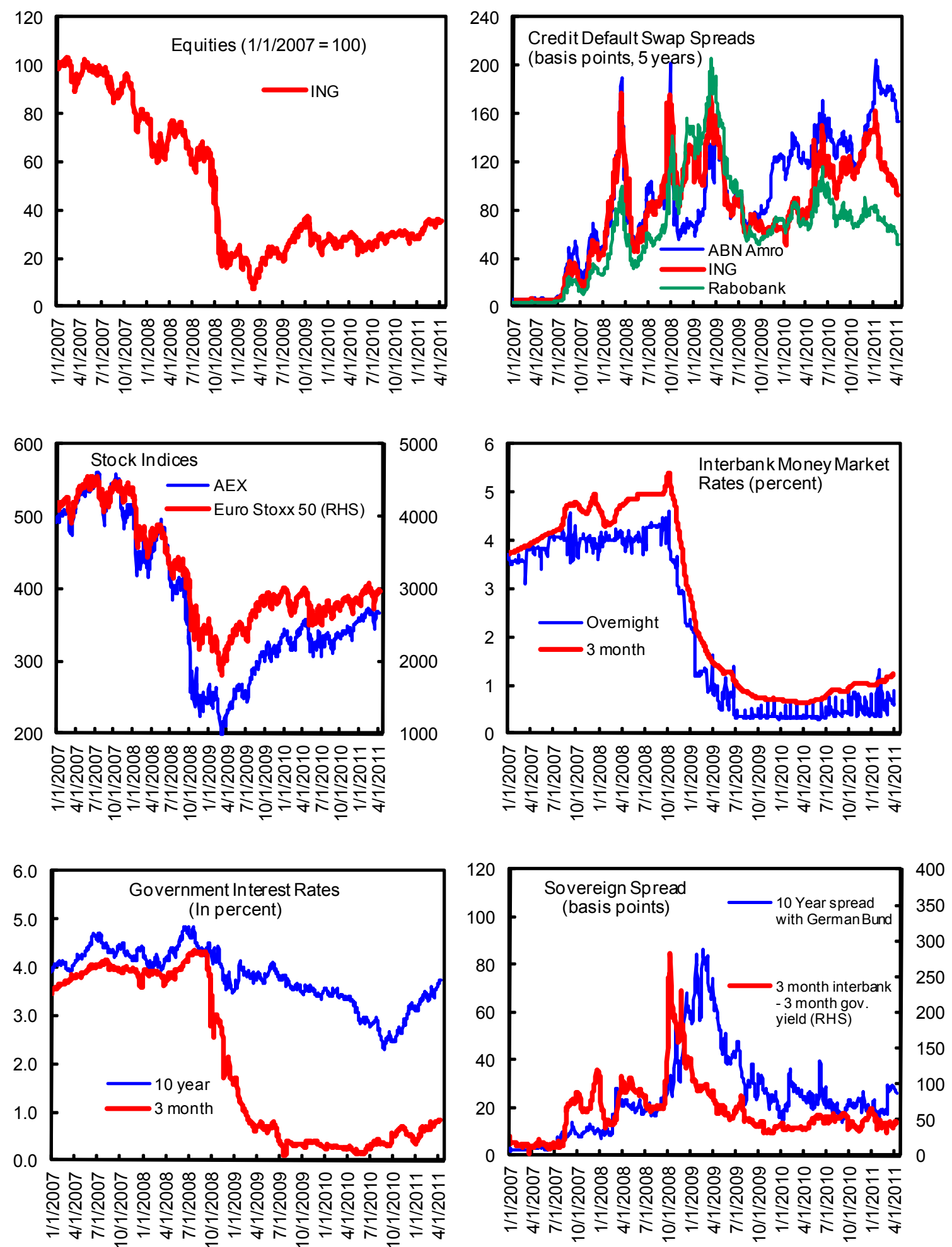

Sources: Thomson Financial/DataStream and Bloomberg. 
Figure 8. Netherlands: Financial Stability Indicators

(In percent)

Banks' capitalization has recovered but profitability has remained low..

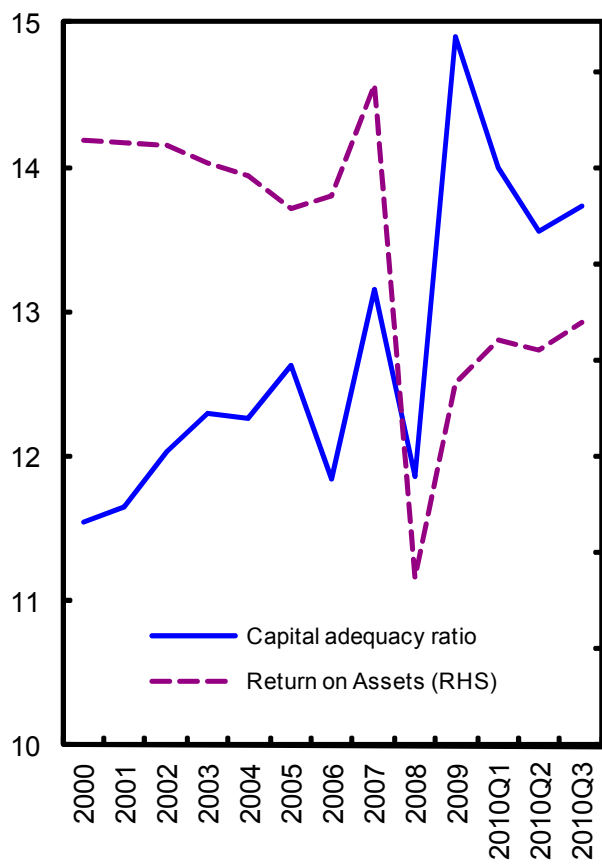

House prices have declined recently, and credit growth has slowed.

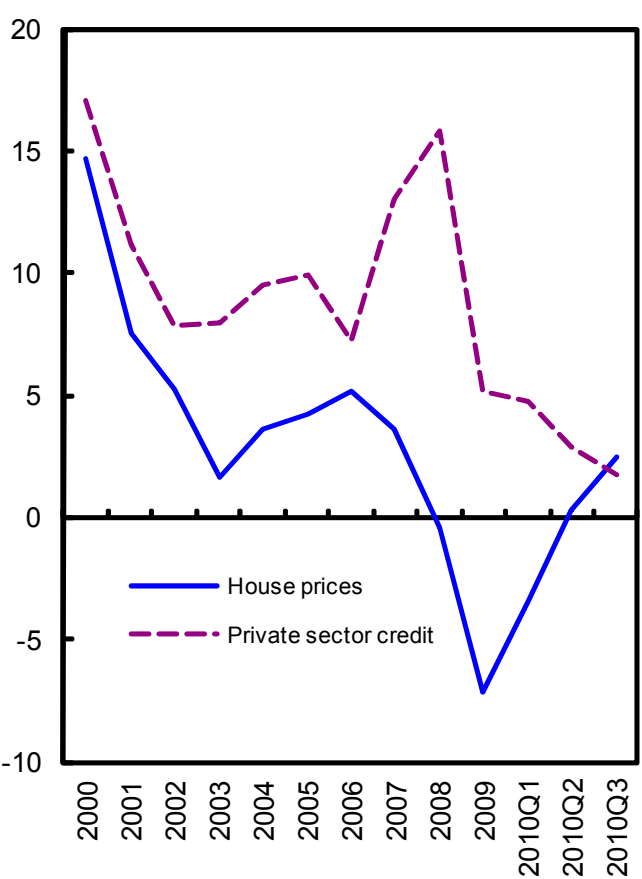

... and the financial positions of p rivate pension and in surance companies have deteriorated.
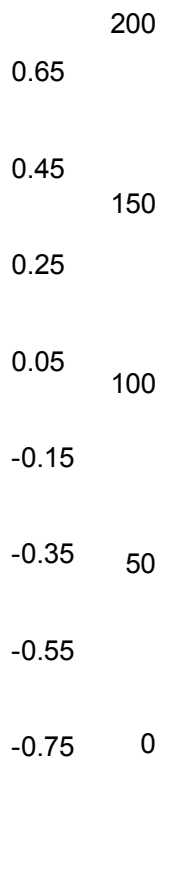

Households debt has tren ded upwards while nonfinancial corporations have reduced leverage.

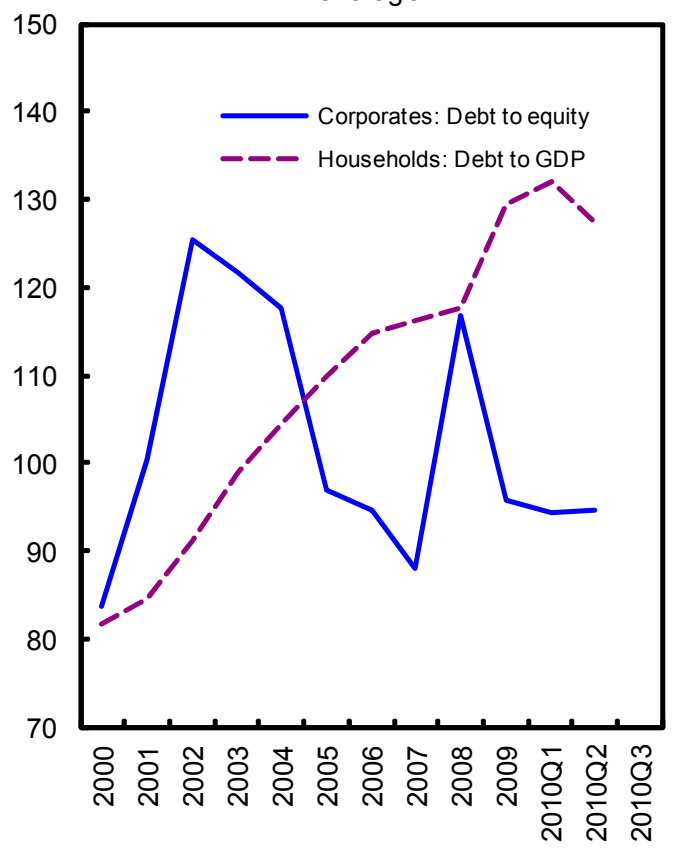

Sources: Global In sight; data provided by the authorities; and IMF, IFS. 
Figure 9. Netherlands: Monetary Conditions
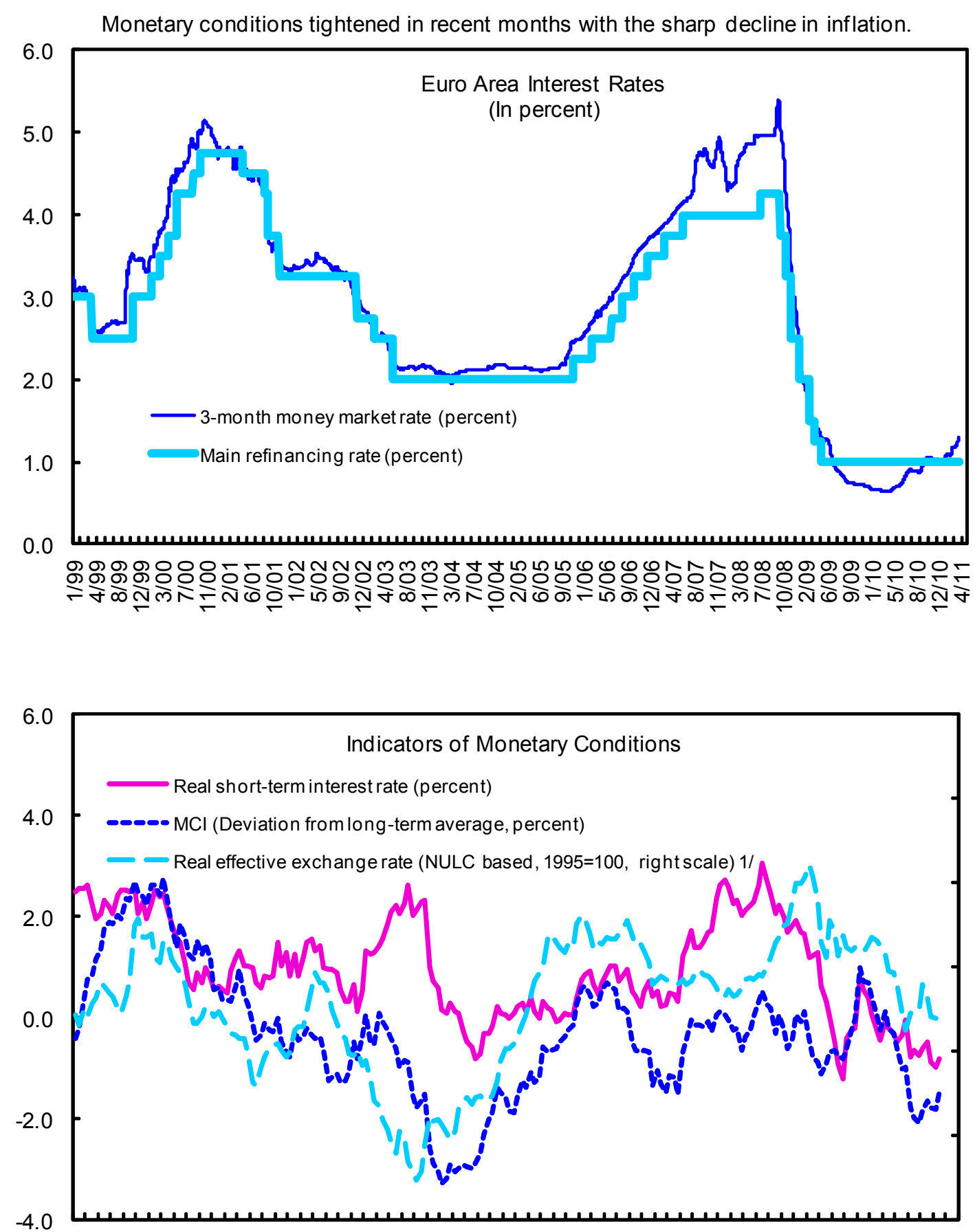

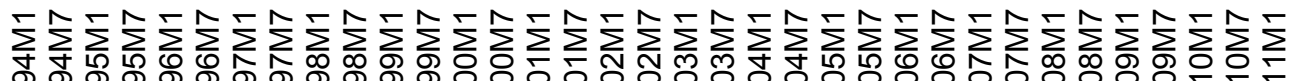

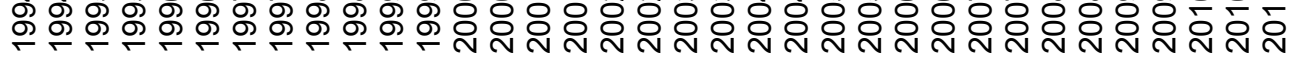

Sources: Global Insight; and IMF, IFS.

$1 /$ An increase implies less accommodative conditions. 
Figure 10. Netherlands: Real Estate Market Developments
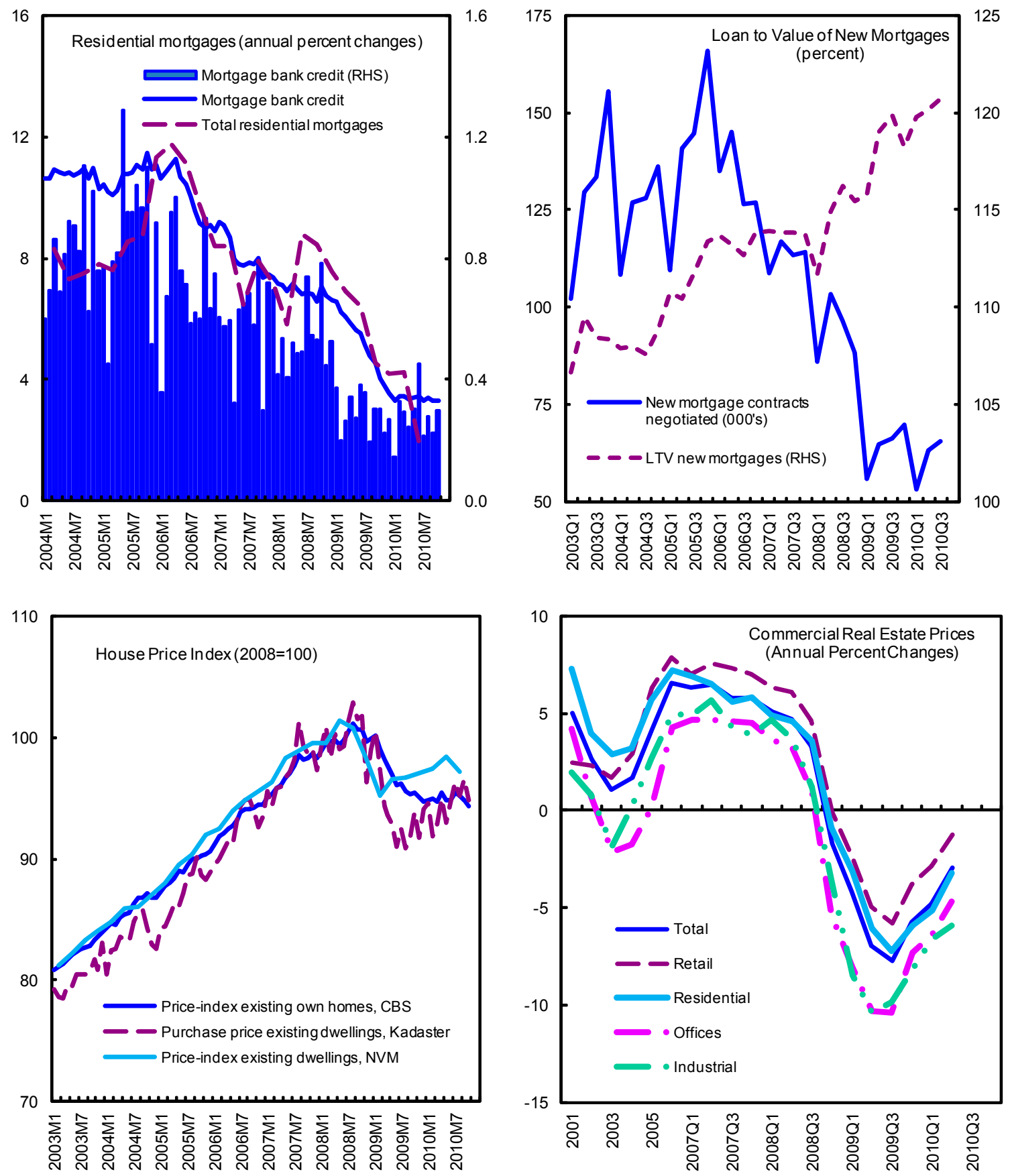

Source:DNB. 
Figure 11. Netherlands: Tax Comparisons
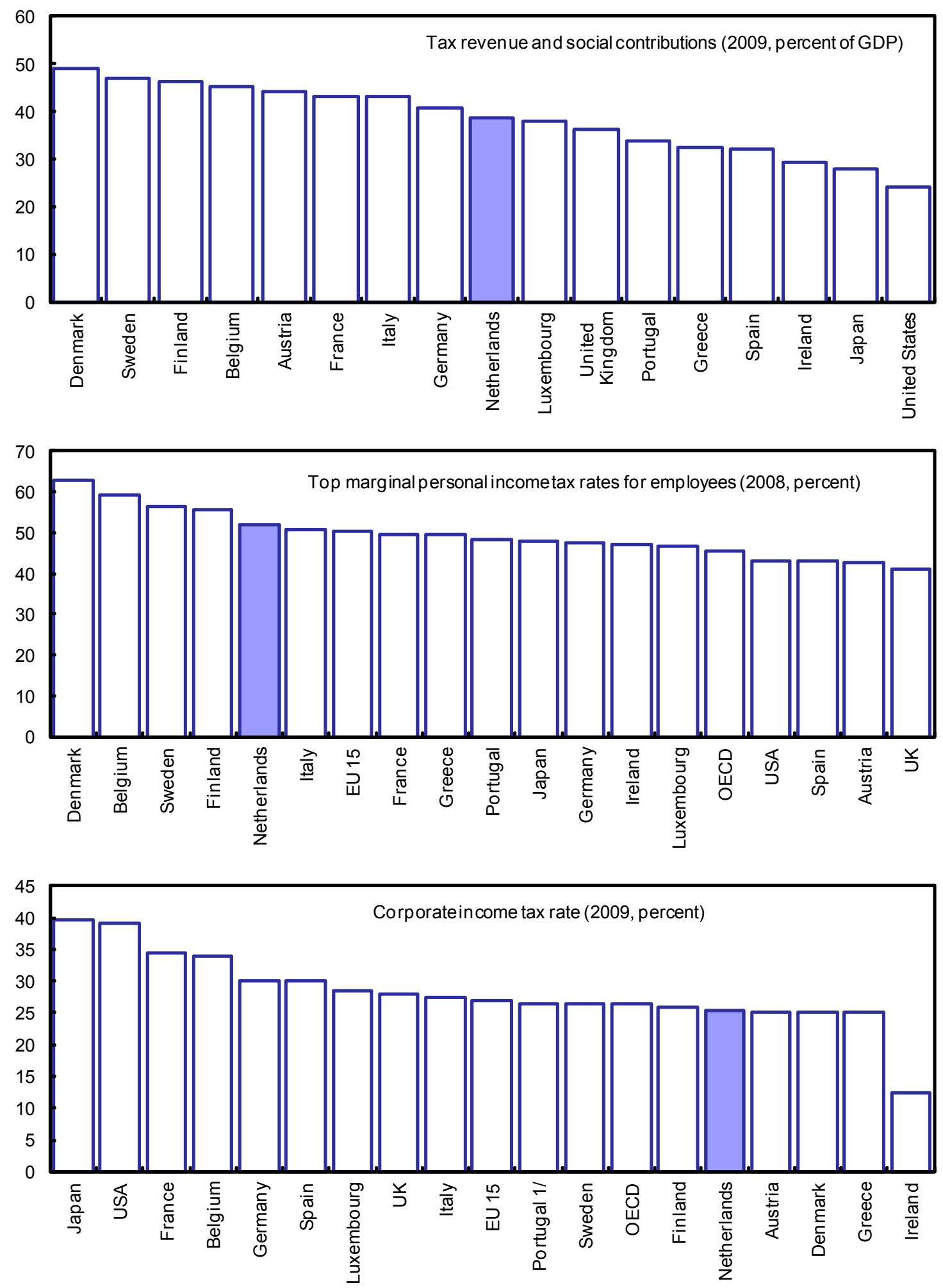

Sources: OECD and IMF, WEO. 


\author{
INTERNATIONAL MONETARY FUND \\ KINGDOM OF THE NETHERLANDS-NETHERLANDS
}

Staff Report for the 2011 Article IV Consultation-Informational Annex

Prepared by the European Department

May 19, 2011

Contents

Page

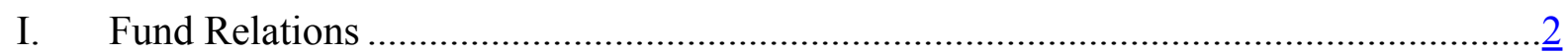

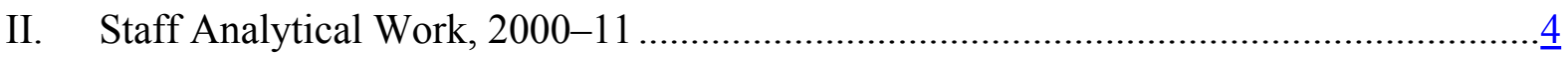

III. Past Fund Policy Recommendations and Implementation.............................................. $\underline{6}$

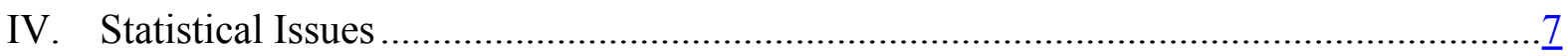




\section{ANNEX I. NETHERLANDS: FUND RELATIONS}

(As of April 30, 2011)

I. Membership Status: Joined December 27, 1945; Article VIII.

II. General Resources Account:

Quota

Fund holdings of currency

Reserve position in Fund

III. SDR Department:

Net cumulative allocation

Holdings

\section{SDR Million}

$5,162.40$

$3,728.73$

$1,433.68$

SDR Million

$4,836.63$

$4,865.60$

\section{Percent of Quota}

100.00

72.23

27.77

Percent of Allocation 100.00 100.60

IV. Outstanding Purchases and Loans: None

V. Latest Financial Arrangements: None

VI. Projected Obligations to Fund (SDR million; based on existing use of resources and present holdings of SDRs):

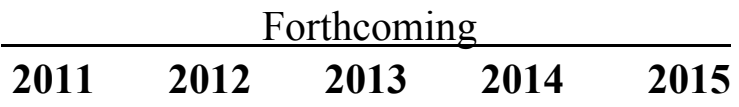

Principal

Charges/interest

Total

$\begin{array}{llll}\underline{0.06} & \underline{0.06} & \underline{0.06} & \underline{0.06}\end{array}$

\section{Exchange Rate Arrangements:}

The Netherlands' currency is the euro, which floats freely and independently against other currencies.

\section{Article IV Consultation:}

Discussions for the 2011 Article IV consultation were held in Amsterdam and The Hague from March 17 to 28, 2011. The staff report for the 2009 Article IV Consultation (IMF Country Report No. 10/34, February 2010) was considered by the Executive Board on January 11, 2010. The Article IV discussions with the Netherlands are on the standard 12month consultation cycle. 


\section{Exchange Restrictions:}

The Netherlands maintains an exchange system free of restrictions on payments and transfers for current international transactions, except for restrictions maintained solely for security reasons. These measures are established by European Union regulations and have been notified to the Fund pursuant to Executive Board Decision No. 144-(52/51). 


\section{AnneX II. Netherlands: Staff Analytical Work, 2000-11}

\section{Fiscal Policy}

- Asset Booms, Sectoral Changes, and the Estimation of Dutch Structural Fiscal Balances, Analytical Note 6, 2011 Selected Issues and Analytical Notes.

- Fiscal Sustainability and Optimal Consolidation Paths in the Netherlands, Analytical Note 7, 2011 Selected Issues and Analytical Notes.

- Modeling Optimal Fiscal Consolidation Paths in a Selection of European Countries, Analytical Note 8, 2011 Selected Issues and Analytical Notes.

○ Long Run Fiscal Sustainability in the Netherlands, Analytical Note 5, IMF Country Report No. 10/34.

- Volatility of Tax Revenues in the Netherlands, IMF Country Report No. 06/284.

- Budgetary Policymaking in the Netherlands, IMF Country Report No. 05/225.

- Recent Fiscal Developments in the Netherlands, IMF Country Report No. 04/301.

- Medium-Term Fiscal Policy, IMF Country Report No. 02/123.

○ Health Care Reform, IMF Country Report No. 02/123.

\section{The Financial Sector}

- Costs and Benefits of Eliminating Mortgage Interest Deductibility, Analytical Note 9, 2011 Selected Issues and Analytical Notes.

○ Recent Development in the Dutch housing Market, Analytical Note 4, 2011 Selected Issues and Analytical Notes.

○ Macro-Financial Linkages, Analytical Note 3, 2011 Selected Issues and Analytical Notes.

- Dutch Housing Markets: What Went Up Will Come Down?, Analytical Note 1, IMF Country Report No. 10/34

- Macro-Financial Linkages in the Netherlands, Analytical Note 2, IMF Country Report No. 10/34

- Capitalization of the Dutch Banking System, Analytical Note 4, IMF Country Report No. 10/34

- House Prices in the Netherlands: Determinants, Concerns, and Considerations Related to Phasing Out the Tax Deductibility of Mortgage Interest Payments, IMF Country Report No. 06/284.

- The Financial Sector in the Netherlands: A Health Check and Progress Report on the FSSA Recommendations, IMF Country Report No. 05/225.

○ House Prices in the Netherlands, IMF Country Report No. 05/225.

- Second Pillar Pensions, Stock Market Returns, and Labor Demand, IMF Country Report No. 03/240. 


\section{Labor Markets}

- Unemployment in the Netherlands: A Unique Experience or a Model that Can be Imitated?, Analytical Note 1, 2011 Selected Issues and Analytical Notes.

- Wage Bargaining in the Netherlands, IMF Country Report No. 03/240.

- Inactivity and Poverty Traps, IMF Country Report No. 02/123.

- Reform of the Disability Program, IMF Country Report No. 02/123.

- The Labor Income Tax Credit in an International Perspective, IMF Country Report No. 01/96.

\section{Growth, Productivity, and Related Cyclical Issues}

- International Trade, Fiscal and Financial Spillovers, Analytical Note 2, 2011 Selected Issues and Analytical Notes.

- Potential Output Estimates and Structural Policy, Analytical Note 5, 2011 Selected Issues and Analytical Notes.

- The Crisis and Potential Output in the Netherlands, Analytical Note 3, IMF Country Report No. 10/34

- Potential Growth and Total Factor Productivity in the Netherlands, IMF Country Report No. 06/284.

- The External Competitiveness of the Dutch Economy: A Short Note on Evidence from both Aggregate and Disaggregate Data, IMF Country Report No. 05/225.

○ Long-Run Household Consumption Equilibrium in the Netherlands, IMF Country Report No. 05/225.

- Recent Productivity Trends in the Netherlands, IMF Country Report No. 04/301.

- Estimating Potential Growth and Output Gaps for the Netherlands, IMF Country Report No. 03/240.

○ Dealing with Cyclical Tensions, IMF Country Report No. 00/88. 


\section{Annex III. Netherlands: Past Fund Policy Recommendations And Implementation}

Fiscal Policy: Staff endorsed the substantial structural fiscal relaxation of the authorities during the global crisis in 2009-10, but also encouraged the authorities to embark on strong consollidation from 2011 onward as economic recovery commenced, given an estimated sustainability gap of 8 percent of GDP in 2011. Other recommendations include closer coordination between the central government and the local governments, and refinements to enhance the transparency and reduce the procyclicality of the fiscal framework (e.g., reporting of tax expenditures in the budget and their inclusion in the expenditures ceiling, and exclusion of unemployment benefits from the expenditure ceiling).

Labor Market: Past recommendations included tightening unemployment benefits, abolishing fiscal incentives for early retirement, reducing inactivity traps, reassessing disability entitlements, and liberalizing employment protection legislation.

Product Market: The Fund has generally supported the authorities' own liberalization program, including the regional unbundling of the energy market, the reduction in required licenses and permits, and, more generally, the efforts to increase competition and reduce the cost of doing business.

Financial Sector: the 2004 Financial Sector Stability Assessment (FSSA) and subsequent Article IV consultations have recommended passage of a new Financial Supervision Act, clarifying the framework for financial sector supervision and the authority of the minister, improvements in security settlement systems, introduction of the new regulatory framework for pension funds, expanding stress testing models, strengthening the AML-CFT framework, reducing mortgage interest deductibility, introducing a mortgage code of conduct to help contain high LTV mortgages.
Fiscal consolidation of some $3 \frac{1}{2}$ percentage points of GDP, in structural terms, is planned for 2011-15. The authorities have also improved coordination between various levels of government, excluded the windfalls in interest payments from the expenditures ceiling, and integrated the FES fund into the central government budget. However, after removing unemployment benefits from the expenditure ceilings during the crisis, they have since put them back under the ceilings.

Maximum duration of unemployment benefits was lowered to 38 monthswhich however remains high in international comparison. Tax/benefit incentives for early retirement were reduced, inactivity traps attenuated, marginal tax rates on second earners reduced, and disability rights tightened. Key recommendations not yet taken on board include (i) further improve the design of the unemployment benefits system to encourage search effort, and (ii) further easing the dismissal system and aligning the rate of accumulation of severance payments for workers aged 50 and over with that of other workers.

The stringency of product market regulation has gradually decreased, reflecting continued simplification in barriers to entrepreneurship. However, retail distribution should be further liberalized by phasing-out the restriction on shop-opening hours, easing zoning regulations and facilitating the entry of large retail stores.

The authorities have implemented most of these recommendations. Prudential supervision is consolidated at DNB, while market conduct supervision is entrusted to AFM. A Financial Stability Division has been established at DNB and pension regulation has been overhauled. DNB has been conducting stress tests regularly as well as improving the stress test framework. There is still only limited progress regarding mortgage interest deductibility, which remains very generous. Similarly, the mortgage code of conduct has been strengthened, but it has not been very effective in reducing the high LTV ratio. An explicit LTV ratio guideline has been introduced in 2011. 


\section{ANNEX IV. NETHERLANDS: STATISTICAL ISSUES}

(As of May 16, 2011)

\section{Assessment of Data Adequacy for Surveillance}

General: Data provision is adequate for surveillance.

National accounts: As a one-off matter, a number of institutional reforms had a significant impact on national account and other data in 2006. Most importantly, the reform of health care insurance caused a significant reclassification of private consumption into public consumption. This shift had a big impact on the growth rates of the components concerned, but overall GDP was not affected.

\section{Data Standards and Quality}

Subscriber to the Fund's Special Data

Data ROSC is available.

Dissemination Standard since June 11, 1996. 


\section{Netherlands: Table of Common Indicators Required for Surveillance (As of May 16, 2011)}

\begin{tabular}{|c|c|c|c|c|c|c|c|}
\hline & \multirow{2}{*}{\begin{tabular}{|c|}
$\begin{array}{c}\text { Date of } \\
\text { Latest } \\
\text { Observation }\end{array}$ \\
\end{tabular}} & \multirow{2}{*}{$\begin{array}{c}\text { Date } \\
\text { Received }\end{array}$} & \multirow{2}{*}{$\begin{array}{l}\text { Frequency } \\
\text { of } \\
\text { Data } / 7\end{array}$} & \multirow{2}{*}{$\begin{array}{c}\text { Frequency } \\
\text { of } \\
\text { Reporting } / 8\end{array}$} & \multirow{2}{*}{$\begin{array}{c}\text { Frequency } \\
\text { of } \\
\text { Publication } \\
\text { /8 }\end{array}$} & \multicolumn{2}{|c|}{ Memo Items: } \\
\hline & & & & & & $\begin{array}{c}\text { Data Quality- } \\
\text { Methodological } \\
\text { Soundness } / 9 \\
\end{array}$ & $\begin{array}{l}\text { Data Quality- } \\
\text { Accuracy and } \\
\text { Reliability /10 } \\
\end{array}$ \\
\hline Exchange Rates & Current & Current & $\begin{array}{l}\text { Daily and } \\
\text { Monthly }\end{array}$ & $\begin{array}{l}\text { Daily and } \\
\text { Monthly }\end{array}$ & $\begin{array}{l}\text { Daily and } \\
\text { Monthly }\end{array}$ & & \\
\hline $\begin{array}{l}\text { International Reserve Assets and Reserve } \\
\text { Liabilities of the Monetary Authorities } / 1\end{array}$ & $3 / 11$ & $4 / 11 / 11$ & Monthly & Monthly & Monthly & & \\
\hline Reserve/Base Money 2/ & $3 / 11$ & $4 / 11 / 11$ & Monthly & Monthly & Monthly & & \\
\hline Broad Money 2/ & $3 / 11$ & $4 / 29 / 11$ & Monthly & Monthly & $\begin{array}{l}\text { Weekly } \\
\text { and } \\
\text { Monthly }\end{array}$ & & \\
\hline Central Bank Balance Sheet & $3 / 11$ & $4 / 11 / 11$ & Monthly & Monthly & Monthly & & \\
\hline $\begin{array}{l}\text { Consolidated Balance Sheet of the } \\
\text { Banking System }\end{array}$ & $3 / 11$ & $4 / 29 / 11$ & Monthly & Monthly & Monthly & & \\
\hline Interest Rates /3 & Current & Current & $\begin{array}{l}\text { Daily and } \\
\text { Monthly }\end{array}$ & $\begin{array}{l}\text { Daily and } \\
\text { Monthly }\end{array}$ & $\begin{array}{l}\text { Daily and } \\
\text { Monthly }\end{array}$ & & \\
\hline Consumer Price Index & $4 / 11$ & $5 / 9 / 11$ & Monthly & Monthly & Monthly & O, O, LO, O & $\mathrm{O}, \mathrm{O}, \mathrm{O}, \mathrm{O}, \mathrm{O}$ \\
\hline $\begin{array}{l}\text { Revenue, Expenditure, Balance and } \\
\text { Composition of Financing } / 4-\text { General } \\
\text { Government } / 5\end{array}$ & Q4 2011 & $03 / 11$ & Quarterly & Quarterly & Quarterly & LO, LO, LO, O & $\mathrm{LO}, \mathrm{O}, \mathrm{O}, \mathrm{O}, \mathrm{O}$ \\
\hline $\begin{array}{l}\text { Revenue, Expenditure, Balance and } \\
\text { Composition of Financing } / 4-\text { Central } \\
\text { Government }\end{array}$ & Q4 2011 & $03 / 11$ & Quarterly & Quarterly & Quarterly & & \\
\hline $\begin{array}{l}\text { Stocks of Central Government and Central } \\
\text { Government-Guaranteed Debt } / 6\end{array}$ & Q4 2011 & $03 / 11$ & Quarterly & Quarterly & Quarterly & & \\
\hline External Current Account Balance & Q4 2011 & $03 / 11$ & Quarterly & Quarterly & Quarterly & $\mathrm{O}, \mathrm{O}, \mathrm{O}, \mathrm{O}$ & $\mathrm{O}, \mathrm{O}, \mathrm{O}, \mathrm{O}, \mathrm{O}$ \\
\hline $\begin{array}{l}\text { Exports and Imports of Goods and } \\
\text { Services }\end{array}$ & Q4 2011 & $03 / 11$ & Quarterly & Quarterly & Quarterly & & \\
\hline GDP/GNP & Q4 2011 & $03 / 11$ & Quarterly & Quarterly & Quarterly & $\mathrm{O}, \mathrm{O}, \mathrm{O}, \mathrm{O}$ & LO, O, O, O, O \\
\hline Gross External Debt & Q4 2011 & $03 / 11$ & Quarterly & Quarterly & Quarterly & & \\
\hline International Investment Position 7 I & Q4 2011 & $03 / 11$ & Quarterly & Quarterly & Quarterly & & \\
\hline
\end{tabular}

$1 /$ Includes reserve assets pledged of otherwise encumbered.

2/ Pertains to contribution to EMU aggregate.

3/ Both market-based and officially-determined, including discount rates, money market rates, rates on treasury bills, notes and bonds.

4/ Foreign, domestic bank, and domestic nonbank financing.

5/ The general government consists of the central government (budgetary funds, extra budgetary funds, and social security funds) and state and local governments.

6/ Including currency and maturity composition.

$7 /$ Includes external gross financial asset and liability positions vis-à-vis nonresidents.

8/ Daily (D); weekly (W); monthly (M); quarterly (Q); annually (A); irregular (I); and not available (NA).

9/ Reflects the assessment provided in the data ROSC (published on January 10, 2008, and based on the findings of the mission that took place October 3-17, 2007) for the dataset corresponding to the variable in each row. The assessment indicates whether international standards concerning concepts and definitions, scope, classification/sectorization, and basis for recording are fully observed (O); largely observed (LO); largely not observed (LNO); not observed (NO); and not available (NA).

10/ Same as footnote 9, except referring to international standards concerning (respectively) source data, assessment of source data, statistical techniques, assessment and validation of intermediate data and statistical outputs, and revision studies. 
Statement by the Staff Representative on the Kingdom of the Netherlands-Netherlands Executive Board Meeting June 10, 2011

1. This statement summarizes developments in the Netherlands since the issuance of the staff report. The additional information does not change the thrust of the staff appraisal.

2. Staff have raised the projections for GDP growth in 2011-12. This reflects recent information showing stronger than expected growth in 2011:Q1 in the Netherlands and also better-than-anticipated economic activity for important trading partners, leading to a corresponding upgrade of their rates of GDP expansion for 2011-12. Specifically:

- $\quad$ The latest Dutch data indicate that GDP y-o-y growth in 2011:Q1 was 2.7 percent ( 0.9 percent with respect to the previous quarter), with investment surprising strongly on the upside. On this basis, we have revised our 2011 GDP growth projection to 1.9 percent, from 1.5 percent previously.

- GDP growth for 2012 is expected at 1.7 percent (compared to 1.5 percent before).

3. As a result of the faster cyclical upturn, projections for the headline fiscal balance have improved modestly. In particular, the deficit for 2011 is now estimated at $3 \frac{1}{2}$ percent of GDP ( $33 / 4$ percent of GDP earlier), and a balanced budget is now expected for 2016 (against a deficit of $1 / 2$ percent of GDP earlier). The projected pace of annual structural fiscal tightening, however, remains broadly unchanged. 
Public Information Notice (PIN) No. 11/79

FOR IMMEDIATE RELEASE

June 22, 2011
International Monetary Fund $70019^{\text {th }}$ Street, NW

Washington, D. C. 20431 USA

\section{IMF Executive Board Concludes 2011 Article IV Consultation with the Kingdom of the Netherlands-Netherlands}

On June 10, 2011 the Executive Board of the International Monetary Fund (IMF) concluded the Article IV consultation with Kingdom of the Netherlands-Netherlands. ${ }^{1}$

\section{Background}

The Netherlands emerged from a deep recession in mid-2009, but the recovery is still frail. The slump was caused by adverse trade and financial spillovers from the global crisis, which also forced large public intervention in the financial sector. Conversely, the subsequent upturn has been stimulated by strong exports. Despite a somewhat slower pace of recovery in the second half of the year, GDP grew $13 / 4$ percent in 2010 . Unemployment has risen only modestly, in part because of labor hoarding, and has been slightly declining since mid-2010. With output still well below potential, inflation has remained subdued until recently, though it is now picking up, also because of rising oil prices. Several indicators suggest that external competitiveness is adequate.

Banking system soundness has improved significantly, though fragilities remain in the financial sector. Banks' regulatory capital adequacy has risen markedly since 2008, largely reflecting government intervention, but equity relative to (unweighted) assets is still comparatively low,

\footnotetext{
${ }^{1}$ Under Article IV of the IMF's Articles of Agreement, the IMF holds bilateral discussions with members, usually every year. A staff team visits the country, collects economic and financial information, and discusses with officials the country's economic developments and policies. On return to headquarters, the staff prepares a report, which forms the basis for discussion by the Executive Board. At the conclusion of the discussion, the Managing Director, as Chairman of the Board, summarizes the views of Executive Directors, and this summary is transmitted to the country's authorities. An explanation of any qualifiers used in summings up can be found here: http://www.imf.org/external/np/sec/misc/qualifiers.htm.
} 
with regulatory capital reflecting the low risk-weighting of mortgages. Nonperforming loans remain manageable at less than 3 percent of total loans. Bank profitability, though still weak, has recovered slightly. However, the coverage ratio for many pension funds is under pressure, owing to extended longevity and persistent low interest rates. The insurance industry is also under strain. A well-designed strategy of gradual exit from the extraordinary public support is being implemented, amid continued restructuring of the financial sector.

The housing and mortgage markets are relatively stable, although vulnerabilities to household balance sheets are rising. House prices steadied from mid-2009 to mid-2010, but seem to have resumed a slow downward drift since then. Affordability-based indicators of house price sustainability remain elevated, albeit having stabilized and slightly improved from two years ago. On the other hand, econometric models do not indicate that house prices are misaligned with fundamentals. However, household debt has grown substantially in relation to disposable income, to over 270 percent in 2010, among the highest in advanced economies. In addition, the loan-to-value (LTV) ratio of new mortgages has continued to rise from its already unusually elevated levels, and exceeded 120 percent in 2010 according to some measures.

The fiscal position deteriorated sharply in 2009 , but is already improving. The general government balance weakened considerably in 2009 , reaching a deficit of $5 \frac{1}{2}$ percent of GDP, on account of substantial stimulus measures and free operation of automatic stabilizers to help stem the impact of the global crisis. However, unexpectedly strong tax receipts in 2010 helped reduce the deficit slightly to $51 / 4$ percent of GDP. Public debt has risen to almost 64 percent of GDP at end-2010, owing also to financial sector assistance not reflected in the deficit. Together with the impact of long-run aging pressures, the fiscal sustainability gap is estimated at about $71 / 2$ percent of GDP. Strong consolidation plans are being implemented with a view to substantially reduce the deficit by 2015 .

\section{Executive Board Assessment}

Executive Directors welcomed the ongoing export-led recovery and noted that remaining slack is dampening inflationary pressures from international commodity prices. Notwithstanding encouraging near-term prospects, Directors considered that the risks to the economic outlook remain skewed to the downside. Over the longer term, fiscal risks could also mount as supplyside dislocations created by the global financial crisis and population aging weigh on potential growth.

Directors supported the authorities' ambitious and frontloaded fiscal consolidation plans, intended to reconstitute policy space and prepare for future increases in age-related spending. Many Directors, however, stressed that fiscal adjustment should be implemented more flexibly than currently allowed by the authorities' fiscal framework, if adverse external shocks slowed significantly the pace of economic activity. In particular, automatic stabilizers should be allowed to operate freely to shore up domestic demand and discretionary support should be considered. 
Directors observed that measures that reduce the impact of population aging on public expenditures or broaden the tax base must be key elements of the authorities' adjustment strategy. Concerning expenditures, Directors agreed that efforts should be addressed at increasing the effective retirement age and restraining growth in costs of health and long-term care.

Directors noted that the soundness of the financial sector has improved, but fragilities remain. They welcomed the results of stress tests in the context of the FSAP update, which show resilience of bank capital and liquidity buffers under extreme scenarios. Nonetheless, Directors saw merit in further strengthening capital or liquidity buffers given high leverage ratios and the upcoming shift to tighter capital standards under Basel III.

Directors agreed that the buildup of vulnerabilities in the housing market warrants close attention in light of the heavy exposure of the financial system to that market, although a few Directors noted the risk-mitigating factors. They encouraged the authorities to consider a further tightening of prudential regulation and granting the Netherlands Central Bank the authority to impose additional restrictions, if necessary.

Directors considered that additional improvements are needed in the areas of rule-making authority and legal protection of supervisors; adequacy of data reporting requirements; resource constraints; and the crisis resolution framework. Directors remarked that efforts should also focus on strengthening the supervision of large international financial institutions.

Directors agreed that low interest rates and rising longevity have put pressure on the coverage ratios of many pension funds. A reform of the pension system is thus needed. In this regard, Directors welcomed the recent agreement between the authorities and social partners, and stressed the need for a transparent communication of any risk-sharing modifications to the current system to induce fitting changes in saving behavior.

Directors agreed that structural reforms continue to be key to lifting the Netherlands's long-term growth prospects. In particular, further reforms of the tax and benefit systems are needed to boost labor participation of women and older workers and facilitate job search.

Public Information Notices (PINs) form part of the IMF's efforts to promote transparency of the IMF's views and analysis of economic developments and policies. With the consent of the country (or countries) concerned, PINs are issued after Executive Board discussions of Article IV consultations with member countries, of its surveillance of developments at the regional level, of post-program monitoring, and of ex post assessments of member countries with longer-term program engagements. PINs are also issued after Executive Board discussions of general policy matters, unless otherwise decided by the Executive Board in a particular case. The staff report (use the free Adobe Acrobat Reader to view this pdf file) for the 2011 Article IV Consultation with the Kingdom of the Netherlands is also available. 
Netherlands: Selected Economic and Social Indicators

\begin{tabular}{|c|c|c|c|c|c|c|}
\hline & 2006 & 2007 & 2008 & 2009 & 2010 & $20111 /$ \\
\hline \multicolumn{7}{|l|}{ Real economy (change in percent) } \\
\hline Real GDP & 3.4 & 3.9 & 1.9 & -3.9 & 1.8 & 1.9 \\
\hline Domestic demand & 4.0 & 3.2 & 2.3 & -4.2 & 0.8 & 1.4 \\
\hline CPI (harmonized) & 1.7 & 1.6 & 2.2 & 1.0 & 0.9 & 2.3 \\
\hline Unemployment rate (in percent) & 3.9 & 3.2 & 2.8 & 3.4 & 4.5 & 4.4 \\
\hline Gross national saving (percent of GDP) & 29.3 & 27.1 & 25.3 & 23.3 & 25.4 & 26.4 \\
\hline Gross investment (percent of GDP) & 20.0 & 20.4 & 20.9 & 18.4 & 18.2 & 19.1 \\
\hline \multicolumn{7}{|l|}{ Public finance (percent of GDP) } \\
\hline General government balance & 0.5 & 0.2 & 0.6 & -5.4 & -5.1 & -3.4 \\
\hline Structural balance & 0.1 & -1.2 & -1.0 & -4.4 & -4.0 & -2.9 \\
\hline General government debt & 47.4 & 45.3 & 58.2 & 60.8 & 63.7 & 64.9 \\
\hline \multicolumn{7}{|l|}{ Interest rates (percent) } \\
\hline Money market rate & 3.0 & 4.0 & 3.8 & 1.0 & 0.8 & $\ldots$ \\
\hline Government bond yield & 3.8 & 4.3 & 4.2 & 3.7 & 3.0 & 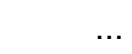 \\
\hline \multicolumn{7}{|c|}{ Balance of payments (in percent of GDP, unless otherwise indicated) 2/ } \\
\hline Trade balance & 7.0 & 7.3 & 7.1 & 6.4 & 7.2 & 8.3 \\
\hline Current account & 9.3 & 6.7 & 4.4 & 4.9 & 7.2 & 7.4 \\
\hline Exports of goods and services & 69.9 & 71.7 & 73.2 & 64.9 & 73.9 & 77.1 \\
\hline Volume, growth (in percent) & 7.3 & 6.4 & 2.8 & -7.9 & 10.9 & 5.2 \\
\hline Imports of goods and services & 61.5 & 62.9 & 64.6 & 57.6 & 65.8 & 68.8 \\
\hline Volume, growth (in percent) & 8.8 & 5.6 & 3.4 & -8.5 & 10.5 & 5.2 \\
\hline Net foreign direct investment & -8.4 & 8.1 & -7.3 & 1.0 & -3.5 & -1.9 \\
\hline Official reserves, excl. gold (US\$ billion) & 10.8 & 10.3 & 11.5 & 17.9 & 18.5 & $\ldots$ \\
\hline \multicolumn{7}{|l|}{ Exchange rate } \\
\hline \multicolumn{7}{|l|}{ Exchange rate regime } \\
\hline U.S. dollar per euro & 1.32 & 1.46 & 1.36 & 1.46 & 1.32 & $\cdots$ \\
\hline Nominal effective rate $(2000=100)$ & 100.3 & 102.4 & 105.2 & 105.5 & 102.2 & $\ldots$ \\
\hline Real effective rate $(2000=100) 3 /$ & 99.1 & 99.7 & 103.7 & 101.3 & 98.3 & 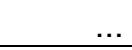 \\
\hline
\end{tabular}

Sources: International Financial Statistics; OECD; Eurostat; Dutch authorities; and IMF staff estimates. 1/ Staff projections.

2/ Transactions basis.

3 / Based on relative normalized unit labor costs. 


\section{Statement by Age Bakker, Executive Director for the Kingdom of Netherlands-Netherlands and Ester Barendregt, Senior Advisor to Executive Director \\ June 10, 2011}

\section{Introduction}

The Dutch authorities thank staff for the constructive meetings during the article IV and FSAP update missions and for their appraisals. The authorities are very appreciative of the analysis and broadly share the assessments.

\section{Economic outlook}

Staff has revised its forecasts for real GDP upward, as explained in the staff statement, from $1 \frac{1}{2}$ percent in 2011 and 2012 to 1.9 and 1.7 percent respectively. In view of recent data, this upward revision seems justified. Indeed, outcomes so far have surprised on the upside. According to Statistics Netherlands (CBS), the Dutch economy grew by 3.2 percent in the first quarter of this year on an annualised basis, the highest recorded in the last three years. Quarter-on-quarter growth was 0.9 percent, a better result than the average growth figure over the six preceding quarters.

\section{Risks to the outlook}

Staff rightly points to external risks, given the Netherlands' extensive trade and financial links. Disruptions in sovereign debt markets, simultaneous fiscal tightening in several advanced European countries and lack of progress in resolving global imbalances indeed pose threats to the recovery. That is why the government in multiple international settings has persistently emphasized the need for international policy coordination.

\section{Housing market}

Staff rightfully points to domestic risks related to high mortgage debt. The authorities have already taken action to strike a balance between mitigating financial risks and ensuring stability in the housing market: in addition to strengthening regulation with regard to mortgage lending, LTV-ratios for new mortgages will be capped at $110 \%$ combined with a requirement to build up savings to pay off at least 50 percent of the mortgage loan at maturity. Although a maximum LTV of 110 percent is still high in international perspective, several country-specific circumstances mitigate risks: the Netherlands traditionally has very low default rates, reflecting inter alia that banks have full recourse against borrowers. Low unemployment (41/4 percent in 2011 and 4 percent in 2012) provides a secure basis for household income. For low income households, risks are mitigated through the National Mortgage Guarantee. And in contrast to many other countries, there is no excess supply of housing. The CPB expects an increase in the number of households in the coming years, while housing production currently is far lower than the long-term need. As is also noted by staff, house prices seem to be in line with fundamentals.

\section{Macro-financial linkages}

Staff finds that as a result of deleveraging, stress in the banking sector and falling profitability, banks tightened credit supply during the crisis. The authorities express some caution about the conclusion in box 2, that the Netherlands has experienced a 'credit crunch' in 2009. This could be misinterpreted as negative credit growth, while de facto credit growth did slow down from the pre-crisis peaks, but remained positive (end 2009 ca 3\% year-on-year). They emphasize that a slowdown in credit demand has also played a role in the weakening of credit growth. Recent research of DNB shows that a 
majority of banks has recently relaxed policies for loans to small and medium-sized enterprises. This is a positive sign that credit supply conditions are improving.

\section{Fiscal policy}

In line with staff's previous recommendations, the government has started to withdraw stimulus measures in 2011 and has made fiscal consolidation one of its main priorities. Consolidation measures are taken to ensure a total reduction of the budget deficit of $€ 18$ billion (nearly 3\% of GDP) by 2015 .

Staff welcomes the commitment to consolidate, but argues for flexible handling of these measures should the recovery stall. In particular, staff calls for enhanced working of the automatic stabilizers. Although the authorities agree that a very severe shock (as in 2008-2009) could warrant relaxation of fiscal adjustment, they believe that debt levels and deficits have reached such heights that fiscal adjustment should have priority over flexibility. The debt level has to be brought back to pre-crisis levels to ensure that government finances can absorb future shocks without raising market tensions. Moreover, age-related spending (pensions and health care) is expected to increase significantly over the coming decades, putting further pressure on the government budget balance. Therefore the government feels strongly that consolidation should be undertaken straight away. As for the automatic stabilizers, according to estimates of the Ministry of Finance, they can function freely without reaching their ceilings (as set in the coalition-agreement) even in a protracted period of zero-growth.

\section{Pension reform}

The IMF rightly points to the low interest rate environment and increased longevity as major causes of the current low coverage ratios of Dutch pension funds. The Dutch authorities agree with the IMF recommendation to recalibrate the second-pillar pensions. Tripartite consultation between unions, employers and the government are ongoing, and aim to link the pension age to life expectancy. The nature of the pension contracts has also been subject of debate, in particular the possibility to transfer more investment risks to the participants. The government has already submitted a bill to raise the retirement age to 66 in 2020 and to tighten the fiscal stimulation of second-pillar pensions. In case the social partners are unable to reach agreement, further measures may be taken, depending on whether a majority in parliament can be formed on this issue. The authorities fully agree with staff's recommendation to communicate clearly to the public any such changes.

\section{Other reforms}

The Dutch authorities agree with staff that further reforms are needed to ensure fiscal sustainability. The aging population in particular poses important challenges. The authorities embrace staff's recommendation that participation in the labor market should be increased and are already undertaking action: participation is being strengthened through education policies and fiscal measures that encourage job search. This could lead to long-term employment increases of $1.1 \%$ in structural terms, according to the CPB's medium-term forecast.

\section{FSAP}

The FSAP update has been a comprehensive exercise, performed by a professional and dedicated team. It was well-timed and very useful for the authorities. The FSAP shows a high level of observance with the BCP, IAIS and IOSCO standards. It confirms the high quality of the supervisory framework and the improvements that have been realized in the Netherlands since the FSAP mission of $2003 / 2004$. The financial sector in the Netherlands has recovered after the financial crisis. In the 
context of the vulnerable international environment, the authorities are comforted by the results of the stress tests performed as part of the FSAP. The stress tests show that the financial sector currently seems to be robust, even under extremely difficult conditions. All banks are able to withstand even the most severe test that is included in the FSAP. Notwithstanding these findings, the authorities remain vigilant of risks.

\section{New initiatives}

Looking forward, supervisors and regulators must continue to adapt to lessons learned and constant changes in the financial markets. The recommendations of the IMF are therefore welcome and are considered carefully. Several initiatives have already been taken and after the Board meeting, Parliament will be informed of the planned course of action to address the recommendations made by the IMF. Highlights are:

\section{- DNB's Action Plan}

DNB has embarked on a reform program to make its supervision more intrusive and conclusive. This includes the creation of a new supervisory division within DNB since January 2011 that comprises several expertise centers and a separate department with a focus on early intervention.

\section{- $\quad$ Strengthening the Crisis Management Framework}

Draft legislation proposes to extend the powers of DNB to organize a timely and orderly restructuring of a troubled financial institution. It also enables the Minister of Finance to take immediate action regarding a financial institution in case the stability of the financial system is under serious and immediate threat. In addition, it aims to resolve the problem of so-called trigger events, where the measures of the supervisor or the Minister of Finance unintentionally lead to immediate fulfillment or termination of existing contracts. The aimed date of entry into force is mid 2012. In addition to this framework, the deposit guarantee scheme will be reformed to an ex-ante funded risk-based scheme.

\section{- $\quad$ Introduction of Solvency II}

This will bring supervisory practice of the insurance sector further in line with the IAIS core principles and important recommendations of the IMF: capital adequacy standards will be more robust and risk-sensitive. The quarterly reports that are now received from the institutions on an informal basis, will then be formally required. DNB's ability for group-wide supervision will be strengthened, including more stringent rules on intragroup transactions. In addition to the Solvency II framework, the AFM has also strengthened the supervision of intermediaries.

\section{- Strengthening International Supervision}

The authorities will continue to contribute to strengthening international cooperation, including in colleges of supervisors and crisis management groups. Supervisory resources will be increased and the scope of supervision will be strengthened under Solvency II and the review of the financial conglomerates directive.

- Macro-prudential analysis and policy

DNB is developing a macroprudential framework and is working on the design and implementation of macroprudential instruments. The extent to which a formal mandate for macroprudential policy would be needed is under investigation. Furthermore, DNB supports implementation of a framework for 
systemically important financial institutions and has publicly announced that it will roll out this framework proportionately to all Dutch SIFIs, whether domestic or global.

- Other FSAP recommendations

Data availability - both for micro- and macroprudential purposes - will also be improved. This has been identified as a specific supervisory theme of DNB for 2011. The Minister has recently announced proposals with regard to the institutional framework and the division of responsibilities between the Ministry of Finance and the supervisors. In reaction to the staff's recommendations on regulatory powers, the authorities will consider whether the scope for supervisors to set technical rules should be widened. Also, in line with the recommendation of the IMF, the Ministry of Finance and the Ministry of Justice have recently announced legislation to limit the liability of the financial supervisors. Supervisors have welcomed this initiative.

\section{Other lessons}

The FSAP-team made an analysis of the Twin Peaks supervisory model in the Netherlands and concludes that the case for the model remains strong. Nevertheless, the authorities' experiences in the crisis have revealed areas for further strengthening: prudential supervision can benefit from synergies in a cross-sectoral supervisory approach. More flexible and risk-based use of resources would enable DNB to better focus activities on that part of the financial sector that is most susceptible to systemic risk. In addition, the Twin Peaks model provides opportunities to further combine financial stability analysis into micro-prudential supervision and vice versa. Finally, recent experience has shown that conduct-of-business problems can easily turn into prudential problems. Coordination between the two supervisors therefore remains important.

On a final note, the authorities attach great importance to European and international cooperation to enhance the regulatory system and practice. They therefore look forward to continue discussions with the IMF and other regulators and supervisors worldwide to take on the challenge to build a stronger and more robust framework for the financial sector. 